\title{
New naturally occurring mineral phases from the Krásno - Horní Slavkov area, western Bohemia, Czech Republic
}

\author{
Nové minerální fáze z oblasti Krásno - Horní Slavkov, západní Čechy, Česká republika
}

\author{
(43 figs, 21 tabs) \\ JIŘÍ SEJKORA ${ }^{1}$ - RADEK ŠKODA² - PETR ONDRUŠ ${ }^{3}$ \\ ${ }^{1}$ Department of Mineralogy and Petrology, National Museum, Václavské nám. 68, CZ-115 79 Prague 1, Czech Republic \\ ${ }^{2}$ Institute of Earth Sciences, Faculty of Science, Masaryk University, Kotlářská 2, CZ-611 37, Brno, Czech Republic \\ ${ }^{3}$ Biskupský dvůr 2, CZ-110 00 Prague 1, Czech Republic
}

This paper presents description of eleven phases - probably new mineral species - from Krásno - Horní Slavkov, western Bohemia, Czech Republic. The phases characterized are mainly supergene phosphates. All up-to-now available physical and chemical data for individual phases and references to appropriate literature are given.

Key words: new natural phases; supergene minerals; phosphates; Krásno; Horní Slavkov; Czech Republic

\section{Introduction}

In the course of the prolonged study of mineralization in the Horní Slavkov - Krásno ore district, presented in this issue of the Journal (Beran - Sejkora, 2006; Plášil et al. 2006; Sejkora et al. 2006a, b, c), eleven new mineral phases have been encountered. This contribution presents the results of study of these phases.

The potentially new minerals are designated by symbols $\boldsymbol{U N K} 1$ to $\boldsymbol{U N K} 11$, derived from the words unnamed mineral Krásno and number of the phase. Individual phases are characterized to a variable degree, depending mainly on the type and quantity of material available for the study.

\section{Methods of mineral identification}

The surface morphology of samples was studied with the optical microscope Nikon SMZ1500 in combination with attached digital camera Nikon DXM1200F, used for photography in incandescent light. Scanning electron microscopes Tesla BS 340 (J. Sejkora and A. Gabašová; Czech Geological Survey, Prague) and JEOL JSM-6380 (J. Sejkora and J. Plášil, Faculty of Science, Charles University, Prague) were used to image surface details of the samples.

If not stated otherwise, all minerals described in this paper were identified by X-ray powder diffraction analysis. To minimize complicated shape of background due to classic glass sample holder, the samples studied were placed on the surface of a flat silicon wafer from suspension in ethanol. Step-scanned powder diffraction data were collected using the following instruments: Philips X'Pert MPD diffractometer (Czech Geological Survey, Prague) with a metallo-ceramic copper tube was operated at high-voltage of $40 \mathrm{kV}$ and tube current of $40 \mathrm{~mA}$; HZG4-AREM/Seifert diffractometer (National Museum, Prague) with a copper tube was operated at high-voltage $50 \mathrm{kV}$ and tube current of $40 \mathrm{~mA}$; and PANalytical X'Pert Pro diffractometer (Faculty of Science, Charles
University, Prague) with X'Celerator detector, with secondary monochromator, using $\mathrm{CuK} \alpha$ radiation at $40 \mathrm{kV}$ and $30 \mathrm{~mA}$.

The results were processed using X-ray analysis software ZDS for DOS (Ondruš 1993), Bede ZDS Search/ Match ver. 4.5 (Ondruš - Skála 1997); unit-cell parameters were refined by program of Burnham (1962) and by program FullProf (Rodríguez-Carvajal 2005).

Quantitative chemical data were collected with the electron microprobe Cameca SX 100 (J. Sejkora and R. Škoda, Joint laboratory of Masaryk University and Czech Geological Survey, Brno). Studied samples were mounted in the epoxy resin discs and polished. The polished surfaces were coated with carbon layer $250 \AA$ thick. Wavelength dispersion mode and operating voltage of $15 \mathrm{kV}$ were used in all analyses. The beam current and diameter were adjusted to maintain stability of analyzed phases under the electron beam. Stable phases were analyzed using $20 \mathrm{nA}$ current and $2 \mu \mathrm{m}$ beam diameter. Less stable and highly hydrated minerals were analyzed using 10-4 nA and 10-30 $\mu \mathrm{m}$ beam diameter. For smaller aggregates $(<10 \mu \mathrm{m})$ of unstable minerals the beam diameter was as large as possible and the applied beam current was only 1-2 nA. The sequence of analyzed elements was adjusted to particular composition of the analyzed mineral. Volatile and major elements were analyzed first, followed by stable, minor and trace elements. Elevated analytic totals of minerals containing a large amount of hydroxyl group or crystalline water are generally caused by two factors: a) water evaporation under high vacuum conditions, well documented by collapsed crystals; b) water evaporation due to heating of the analyzed spot by electron beam. The dehydrated domain is seen as a notably brighter spot in backscattered electron images. Lower analytical totals for some samples are primarily caused by their porous nature or by poorly polished surface of soft or cryptocrystalline minerals.

In order to minimize peak overlap the following analytic lines and crystals were selected: K $\alpha$ lines: F (PC1, 
fluorapatite/topaz), $\mathrm{Mg}$ (TAP, forsterite), $\mathrm{Na}$ (TAP, albite), Al (TAP, sanidine), As (TAP, InAs), Si (TAP, sanidine), $\mathrm{Cu}$ (TAP, dioptase), K (PET, sanidine), P (PET, fluorapatite) $\mathrm{Ca}$ (PET, andradite), S (PET, barite), Ti (PET, TiO), $\mathrm{Cl}$ (PET, vanadinite), Fe (LIF, andradite), Mn (LIF, rhodonite), $\mathrm{Ni}$ (LIF, NiO), $\mathrm{Zn}$ (LIF, $\mathrm{ZnO}$ ); L $\alpha$ lines: Y (TAP, YAG), Sr (PET, $\left.\mathrm{SrSO}_{4}\right), \mathrm{La}\left(\mathrm{PET}, \mathrm{LaB}_{6}\right)$, Ce (PET, $\left.\mathrm{CeAl}_{2}\right), \mathrm{Sm}\left(\mathrm{LIF}, \mathrm{SmF}_{3}\right)$; Lß lines: Ba (PET, benitoite), $\operatorname{Pr}\left(\mathrm{LIF}, \mathrm{PrF}_{3}\right), \mathrm{Nd}$ (LIF, $\mathrm{NdF}_{3}$ ); $\mathrm{M} \alpha$ lines: Th (PET, $\mathrm{ThO}_{2}$ ), $\mathrm{Pb}$ (PET, vanadinite); Mß lines: Bi (PET, metallic Bi), U (PET, metallic U). Peak counting times (CT) were 10 to $20 \mathrm{~s}$ for main elements and 30 to $60 \mathrm{~s}$ for minor and trace elements. CT for each background was $1 / 2$ of peak time. In case that background was measured only one side of the peak, the counting time was the same as counting on the peak. As far as possible, elements present in minor and trace abundances were measured with highly sensitive crystals LPET a LLIF. Raw intensities were converted to the concentrations using automatic PAP (Pouchou - Pichoir 1985) matrix correction software package.

In analysis of some studied phases, accurate determination of fluorine content is important. Where possible, determination of fluorine was verified by measuring peak area (integrated intensity). This check was done irrespective of the note by Raudsep (1995) that with multilayer crystal monochromators (PC1) the effect of matrix is minimal. Fluorine contents measured by the two methods are practically identical.

\section{Review of identified mineral phases}

\section{UNK1 CaAl silicate phosphate fluoride - $(\mathrm{Ca}, \mathrm{Sr})_{3} \mathrm{Al}_{7}\left(\mathrm{SiO}_{4}\right)_{3}\left(\mathrm{PO}_{4}\right)_{4}(\mathrm{~F}, \mathrm{OH})_{3} \cdot 16.5 \mathrm{H}_{2} \mathrm{O}$}

UNK1 has been found in several samples collected in the Huber open pit. It is confined to cavities in strongly altered phosphate aggregates (Sejkora et al. 2006c), where it belongs to the youngest minerals. Such phosphate accumulations, ranging from $1 \mathrm{~cm}$ to $10 \mathrm{~cm}$ in size and sometimes accompanied by grains of unaltered green fluorapatite up to several $\mathrm{cm}$ long, are deposited in compact quartz. Triplite in these aggregates is almost completely replaced by compact pink-brown fluorapatite and isokite. Also accumulations to 2 by $3.5 \mathrm{~cm}$ composed dominantly of $\boldsymbol{U N K} \mathbf{1}$ were observed, accompanied by whitish fluorapatite. The phase $\boldsymbol{U N K \boldsymbol { I }}$ is accompanied by imperfectly shaped crystals of white and light yellow fluorapatite and rare zoned aggregates of F-rich crandallite, whitish crystals of kolbeckite and whitish earthy aggregates of the younger generation of isokite.

UNK1 forms compact and finely crystalline aggregates of chalk-white colour. This material, together with fluorapatite forms alteration products after the primary phosphate aggregates (Fig. 1). Cavities in these masses carry semi-spherical aggregates of $\boldsymbol{U N K} 1$ to $0.1 \mathrm{~mm}$ with pearly lustre. The same phase forms rich crystalline aggregates deposited on light pink fluorapatite. These ag-

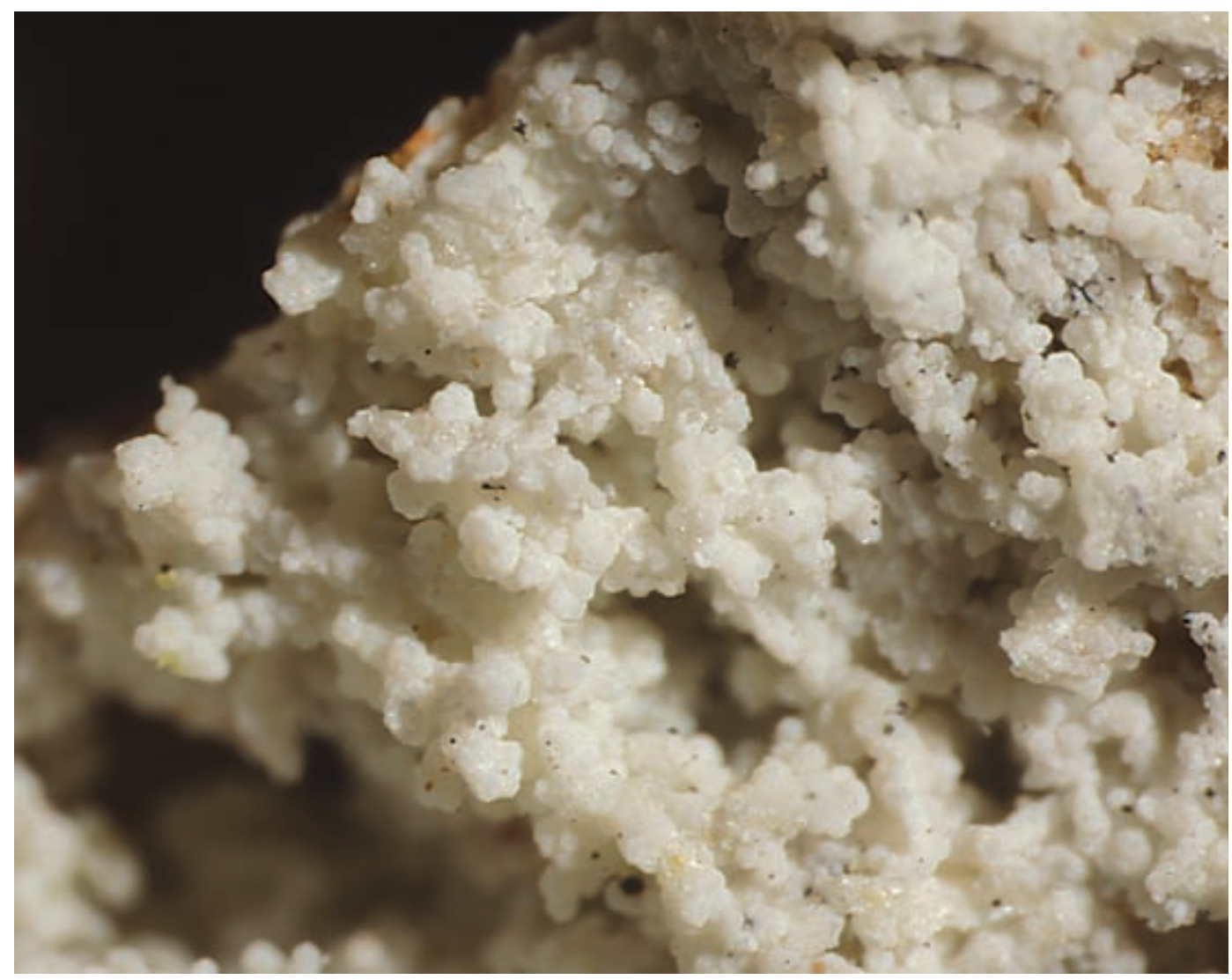

Fig. 1 White aggregates of $\boldsymbol{U N K} \boldsymbol{1}$ with admixture of fluorapatite in cavity of aggregate of the primary phosphate. Huber open pit, Krásno. Width of the area shown $4.5 \mathrm{~mm}$. Nikon SMZ1500, photograph by J. Sejkora. 
gregates of $\boldsymbol{U N K \boldsymbol { 1 }}$ are whitish with a weak yellow or green shade, partly transparent with a greasy lustre. Individual tabular crystals composing the aggregates are about $0.1 \mathrm{~mm}$ long (Fig. 2). Probably the most common are irregular, snow-white aggregates with pearly lustre, deposited in cavities in relict fluorapatite. Such aggregates grade to spheroidal aggregates (Fig. 3) composed of thin platy crystals (Fig. 4) up to $0.1 \mathrm{~mm}$ in size (Fig. 5).

Additional two different mineral assemblages host UNK1. It crystallized as the youngest phase deposited on crystalline aggregates of UNK3 and kolbeckite, together with minerals of the chalcosiderite - turquoise series and pharmacosiderite. The second of the associations includes light yellow to buff crusts up to $3 \mathrm{~mm}$ thick, deposited on $1 \mathrm{~cm}$ long fluellite crystals, which in turn are sitting on milky-coloured fluorapatite in a cavity of quartz gangue.

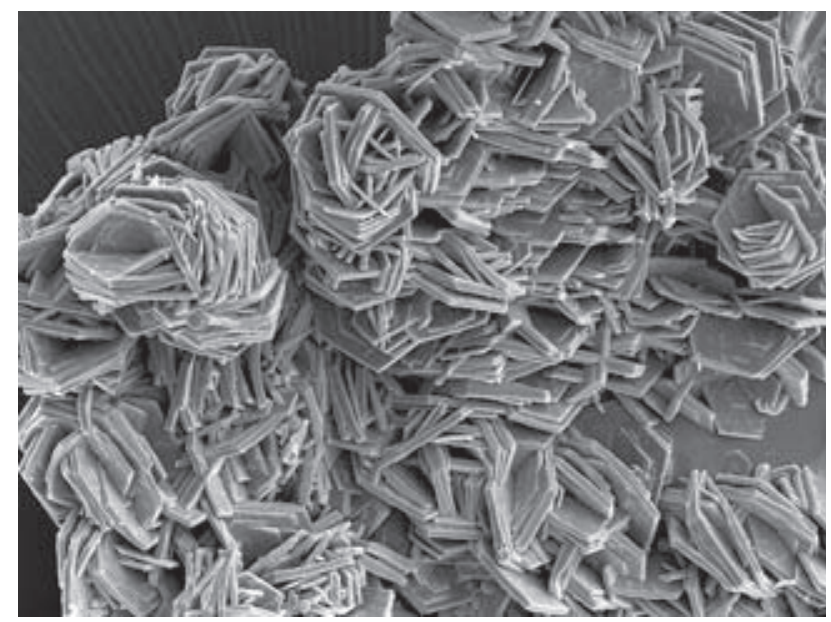

Fig. 2 UNK1 aggregates composed of tabular crystals, Krásno. Width of the area shown $320 \mu \mathrm{m}$. SEM photograph Jeol JSM-6380, J. Sejkora and J. Plášil.

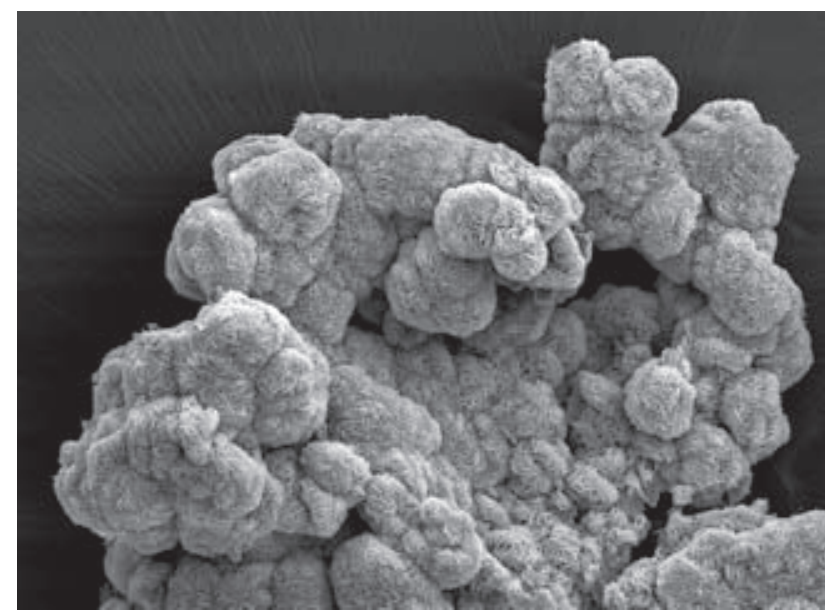

Fig. 3 Semi-spherical aggregates of $\boldsymbol{U N K} \mathbf{1}$, Krásno. Width of the area shown $600 \mu \mathrm{m}$. SEM photograph Jeol JSM-6380, J. Sejkora and J. Plášil.

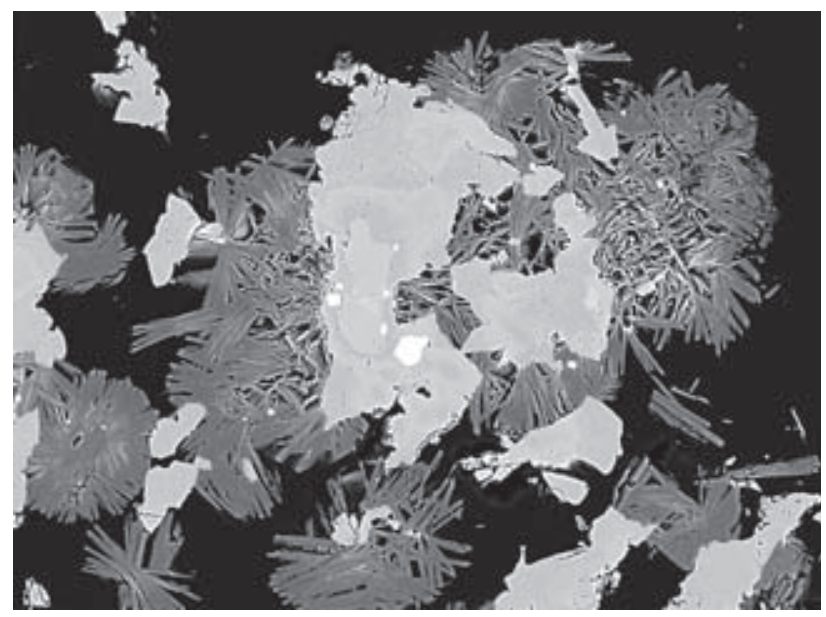

Fig. 4 Semi-spherical aggregates of $\boldsymbol{U N K} \mathbf{1}$ composed of thin tabular crystals (dark grey), deposited on fluorapatite and other phosphates (light grey). Width of the area shown $400 \mu \mathrm{m}$ BSE photograph, Cameca SX100, by J. Sejkora and R. Škoda.
Fig. 5 Detail of tabular crystals of $\boldsymbol{U N K} \mathbf{1}$, Krásno. Width of the area shown $80 \mu \mathrm{m}$. SEM photograph Jeol JSM-6380, J. Sejkora and J. Plášil.

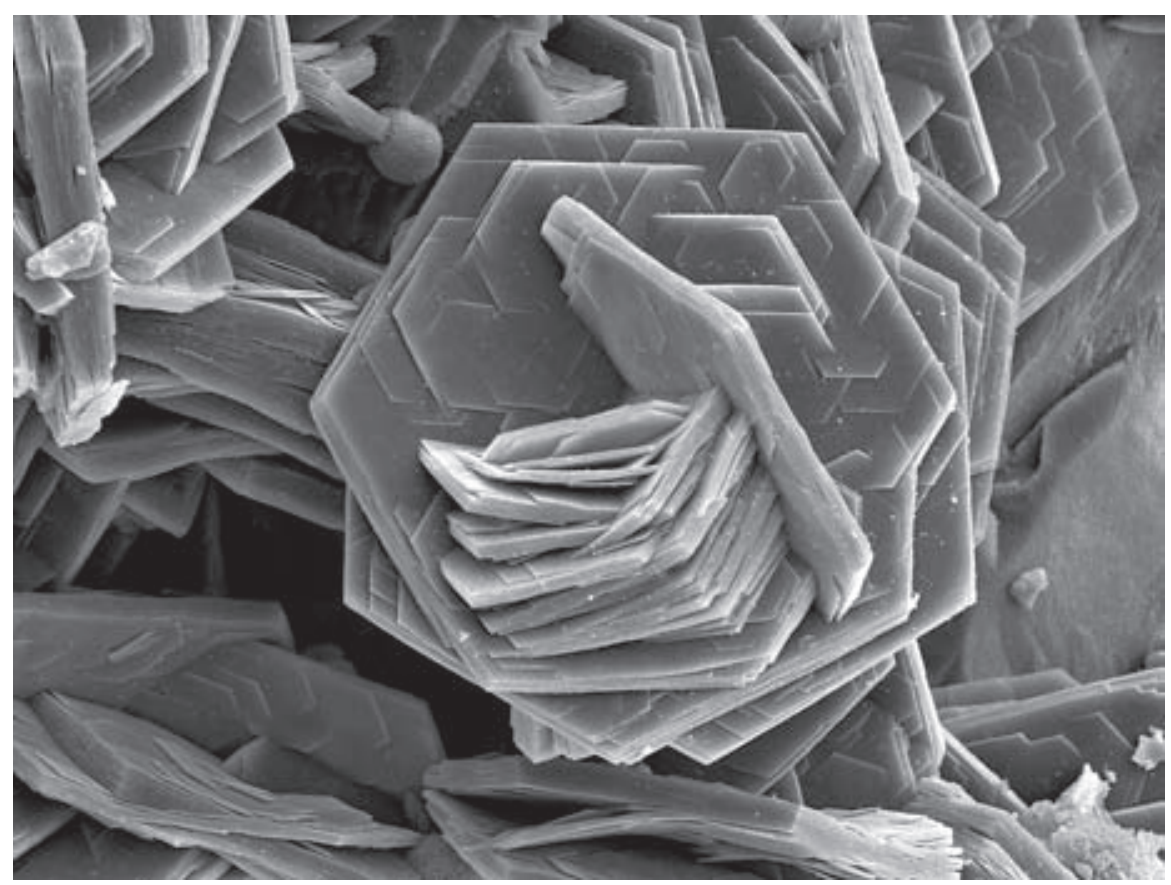


The X-ray powder data for $\boldsymbol{U N K} \boldsymbol{1}$ (Table 1) are close to data published for perhamite (Dunn - Appleman 1977). Besides differences in diffraction intensities, caused probably by preferred orientation of sample and instrumental differences, the most important difference is in the presence of an intense diffraction maximum with $d$-spacing
Table 2 Unit-cell parameters of $\boldsymbol{U N K \boldsymbol { I }}$ (for hexagonal space group P6/mmm)

\begin{tabular}{|l|cc|}
\hline & $\begin{array}{c}\text { UNK1 Krásno } \\
\text { this paper }\end{array}$ & $\begin{array}{c}\text { perhamite Newry Hill } \\
\text { Dunn - Appleman }(1977)\end{array}$ \\
\hline$a[\AA]$ & $6.9939(6)$ & $7.022(1)$ \\
$c[\AA]$ & $20.200(2)$ & $20.182(5)$ \\
$V\left[\AA^{3}\right]$ & $855.7(1)$ & 861.8 \\
\hline
\end{tabular}

Table 1 X-ray powder diffraction pattern of $\boldsymbol{U N K \boldsymbol { I }}$

\begin{tabular}{|c|c|c|c|c|c|c|c|c|c|c|c|c|c|}
\hline$I_{\text {rel. }}$ & $d$ & $h$ & $k$ & $l$ & $I_{\text {rel. }}{ }^{*}$ & $d^{*}$ & $I_{r e l}$ & $d$ & $h$ & $k$ & $l$ & $I_{\text {rel. }}$ * & $d^{*}$ \\
\hline 97 & 20.186 & 0 & 0 & 1 & & & 15 & 1.992 & 2 & 1 & 5 & 6 & 1.996 \\
\hline 23 & 10.100 & 0 & 0 & 2 & 13 & 10.12 & 56 & 1.934 & 3 & 0 & 3 & 35 & 1.942 \\
\hline 100 & 6.736 & 0 & 0 & 3 & 35 & 6.71 & 18 & 1.916 & 1 & 0 & 10 & 4 & 1.916 \\
\hline 47 & 6.051 & 1 & 0 & 0 & 50 & 6.08 & 30 & 1.875 & 3 & 0 & 4 & 35 & 1.881 \\
\hline 67 & 5.800 & 1 & 0 & 1 & 71 & 5.80 & 55 & 1.835 & 0 & 0 & 11 & 6 & 1.834 \\
\hline 20 & 5.190 & 1 & 0 & 2 & 13 & 5.21 & 15 & 1.806 & 3 & 0 & 5 & 6 & 1.811 \\
\hline 37 & 5.047 & 0 & 0 & 4 & 4 & 5.04 & 64 & 1.748 & 2 & 2 & 0 & 50 & 1.757 \\
\hline 15 & 4.043 & 0 & 0 & 5 & & & 15 & 1.681 & 2 & 0 & 10 & 9 & 1.684 \\
\hline 15 & 3.872 & 1 & 0 & 4 & 6 & 3.889 & 49 & 1.655 & 3 & 0 & 7 & & \\
\hline 60 & 3.496 & 1 & 1 & 0 & 50 & 3.510 & 11 & 1.603 & 2 & 1 & 9 & 9 & 1.604 \\
\hline 27 & 3.361 & 0 & 0 & 6 & 9 & 3.369 & 7 & 1.5520 & 2 & 2 & 6 & 3 & 1.5551 \\
\hline 57 & 3.103 & 1 & 1 & 3 & 50 & 3.115 & 17 & 1.5173 & 1 & 1 & 12 & 13 & 1.5165 \\
\hline 41 & 2.994 & 2 & 0 & 1 & 35 & 3.005 & 7 & 1.5041 & 1 & 0 & 13 & 6 & 1.5003 \\
\hline 56 & 2.942 & 1 & 0 & 6 & 35 & 2.947 & 1 & 1.4965 & 4 & 0 & 2 & 6 & 1.4831 \\
\hline 50 & 2.900 & 2 & 0 & 2 & & & 12 & 1.4957 & 2 & 2 & 7 & & \\
\hline 87 & 2.873 & 1 & 1 & 4 & 100 & 2.882 & 51 & 1.4710 & 2 & 0 & 12 & 18 & 1.4715 \\
\hline 73 & 2.763 & 2 & 0 & 3 & 25 & 2.773 & 10 & 1.4374 & 2 & 2 & 8 & 3 & 1.4219 \\
\hline 33 & 2.644 & 1 & 1 & 5 & 25 & 2.650 & 6 & 1.3985 & 3 & 1 & 8 & & \\
\hline 36 & 2.605 & 1 & 0 & 7 & 13 & 2.606 & 30 & 1.3824 & 2 & 0 & 13 & 13 & 1.3837 \\
\hline 59 & 2.524 & 0 & 0 & 8 & 18 & 2.524 & 12 & 1.3584 & 3 & 0 & 11 & & \\
\hline 25 & 2.425 & 1 & 1 & 6 & 25 & 2.429 & 4 & 1.3450 & 3 & 1 & 9 & 4 & 1.3483 \\
\hline 48 & 2.330 & 1 & 0 & 8 & 9 & 2.330 & 11 & 1.3223 & 2 & 2 & 10 & 6 & 1.3272 \\
\hline 8 & 2.286 & 2 & 1 & 0 & & & 8 & 1.2933 & 3 & 0 & 12 & & \\
\hline 51 & 2.250 & 2 & 0 & 6 & 25 & 2.252 & 7 & 1.2792 & 4 & 1 & 4 & & \\
\hline 15 & 2.231 & 2 & 1 & 2 & & & 9 & 1.2316 & 3 & 0 & 13 & & \\
\hline 21 & 2.168 & 2 & 1 & 3 & 18 & 2.175 & 11 & 1.2178 & 3 & 2 & 8 & & \\
\hline 75 & 2.104 & 1 & 0 & 9 & 35 & 2.104 & 5 & 1.1888 & 0 & 0 & 17 & & \\
\hline 20 & 2.048 & 1 & 1 & 8 & 6 & 2.052 & 9 & 1.1818 & 3 & 2 & 9 & & \\
\hline 10 & 2.018 & 3 & 0 & 0 & & & 11 & 1.1661 & 1 & 0 & 17 & & \\
\hline
\end{tabular}

$\boldsymbol{I}_{r e l .} *$ and $\boldsymbol{d}^{*}-\mathrm{X}$-ray powder data of perhamite from Bell Pit, Newry, Maine, U.S.A (Dunn - Appleman 1977)

of $20.2 \AA$. Refined unit-cell parameters of $\boldsymbol{U N K \boldsymbol { 1 }}$ are close to those of perhamite (Table 2).

The phase UNK1 contains major $\mathrm{Ca}, \mathrm{Al}, \mathrm{Si}, \mathrm{P}$ and usually lower contents of $\mathrm{Sr}$ and $\mathrm{F}$ (Table 3). The general formula of perhamite-like minerals is $\mathrm{A}_{3} \mathrm{~B}_{7}\left(\mathrm{~T}_{(1)} \mathrm{O}_{4}\right)_{3}\left(\mathrm{~T}_{(2)} \mathrm{O}_{4}\right)_{4} \mathrm{X}_{3} \cdot 16.5 \mathrm{H}_{2} \mathrm{O}$. The A-site contains $\mathrm{M}^{1+}$ and $\mathrm{M}^{2+}$ elements, in particular $\mathrm{Ca}, \mathrm{Sr}$, and $\mathrm{Na}$; $B$-site contains $\mathrm{M}^{3+}$ and $\mathrm{M}^{4+}$ elements, dominant $\mathrm{Al}$ and minor $\mathrm{Fe}^{3+}$ and $\mathrm{Ti}$. The first tetrahedral $\mathrm{T}_{(I)}$-site hosts dominant $\mathrm{Si}$, which can be partly substituted by Al (Mills et al. 2004); the $\mathrm{T}_{(2)}$-site is occupied by $\mathrm{P}$, strongly dominating over As. The $X$-site in addition to $(\mathrm{OH})$ and subordinate $\mathrm{Cl}$ contains fluorine.

The A-site in UNK1 from Krásno (Fig. 6) contains Ca (1.82-2.57 apfu), but in difference to perhamite from Newry Hill (Dunn - Appleman 1977), there are moderate contents of $\mathrm{Sr}(0.06$ to $0.72 \mathrm{apfu})$ and minor contents of $\mathrm{Zn}$ (max. 0.10), K (0.07), Na (0.04), Ba, Mn (0.02) and $\mathrm{Pb}$ (max. 0.01 apfu). The occupancy of the $A$-site (2.51-2.84 apfu) indicates possible vacancies. The $B$-site

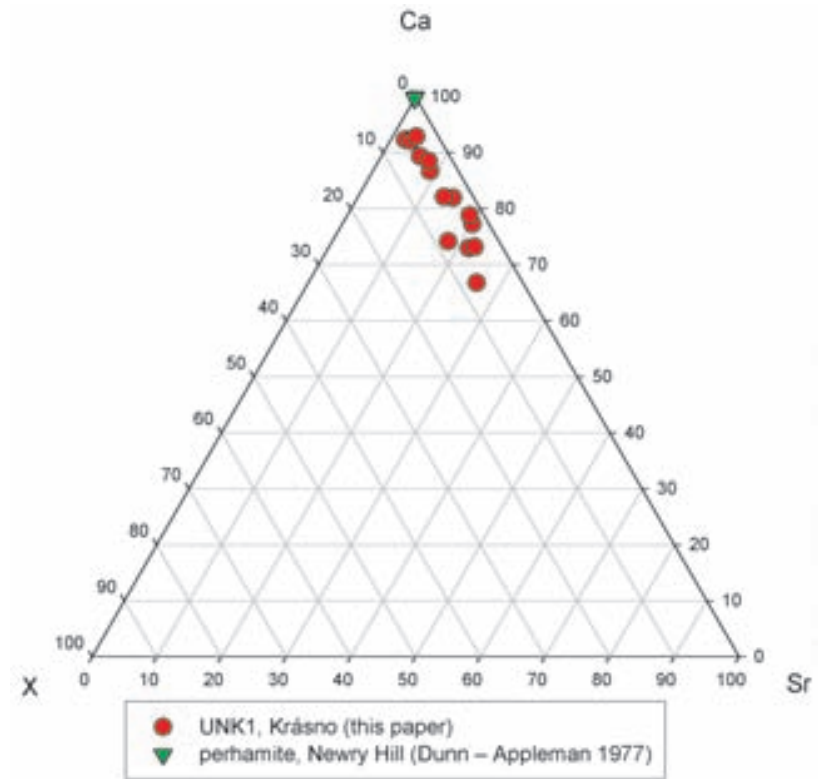

Fig. 6 Ternary plot Ca-Sr-X of occupancy of the $A$-site (atomic ratio) for $\boldsymbol{U N K} 1$ from Krásno. $\mathrm{X}=\mathrm{Na}+\mathrm{K}+\mathrm{Zn}+\mathrm{Ba}+\mathrm{Pb}+\mathrm{Mn}$ 
Table 3 Chemical composition of $\boldsymbol{U N K} \boldsymbol{1}$ (in wt. \%)

\begin{tabular}{|c|c|c|c|c|c|c|c|c|c|c|c|c|c|c|}
\hline & mean & 1 & 2 & 3 & 4 & 5 & 6 & 7 & 8 & 9 & 10 & 11 & 12 & 13 \\
\hline $\mathrm{Na}_{2} \mathrm{O}$ & 0.06 & 0.04 & 0.06 & 0.09 & 0.04 & 0.09 & 0.04 & 0.08 & 0.11 & 0.04 & 0.01 & 0.00 & 0.07 & 0.08 \\
\hline $\mathrm{K}_{2} \mathrm{O}$ & 0.16 & 0.14 & 0.15 & 0.26 & 0.13 & 0.16 & 0.13 & 0.22 & 0.24 & 0.09 & 0.13 & 0.22 & 0.08 & 0.13 \\
\hline $\mathrm{CaO}$ & 10.18 & 8.45 & 8.78 & 9.05 & 9.22 & 11.59 & 11.36 & 11.19 & 11.00 & 9.58 & 9.63 & 11.20 & 9.68 & 11.68 \\
\hline $\mathrm{BaO}$ & 0.07 & 0.22 & 0.00 & 0.00 & 0.08 & 0.07 & 0.00 & 0.24 & 0.00 & 0.00 & 0.04 & 0.20 & 0.04 & 0.10 \\
\hline $\mathrm{SrO}$ & 3.07 & 6.11 & 4.85 & 4.07 & 5.26 & 0.53 & 0.73 & 1.41 & 2.09 & 4.62 & 3.23 & 1.83 & 4.32 & 0.85 \\
\hline $\mathrm{PbO}$ & 0.04 & 0.13 & 0.00 & 0.23 & 0.10 & 0.04 & 0.00 & 0.03 & 0.04 & 0.00 & 0.00 & 0.00 & 0.00 & 0.00 \\
\hline $\mathrm{MnO}$ & 0.04 & 0.11 & 0.06 & 0.05 & 0.05 & 0.06 & 0.06 & 0.07 & 0.04 & 0.03 & 0.02 & 0.05 & 0.00 & 0.00 \\
\hline $\mathrm{ZnO}$ & 0.28 & 0.68 & 0.44 & 0.57 & 0.30 & 0.37 & 0.45 & 0.04 & 0.07 & 0.19 & 0.26 & 0.14 & 0.06 & 0.14 \\
\hline $\mathrm{Al}_{2} \mathrm{O}_{3}$ & 30.18 & 30.76 & 32.71 & 28.73 & 30.74 & 29.78 & 30.34 & 29.39 & 29.33 & 30.00 & 30.56 & 29.74 & 29.79 & 30.43 \\
\hline $\mathrm{Fe}_{2} \mathrm{O}_{3}$ & 0.38 & 1.06 & 0.48 & 0.32 & 0.40 & 0.21 & 0.25 & 0.08 & 0.05 & 1.46 & 0.55 & 0.01 & 0.04 & 0.05 \\
\hline $\mathrm{SiO}_{2}$ & 12.72 & 10.35 & 10.99 & 11.03 & 12.05 & 13.06 & 13.21 & 13.87 & 13.28 & 13.21 & 13.11 & 13.09 & 14.23 & 13.90 \\
\hline $\mathrm{As}_{2} \mathrm{O}_{5}$ & 0.05 & 0.17 & 0.00 & 0.03 & 0.00 & 0.08 & 0.00 & 0.00 & 0.06 & 0.14 & 0.09 & 0.00 & 0.03 & 0.00 \\
\hline $\mathrm{P}_{2} \mathrm{O}_{5}$ & 23.43 & 25.03 & 26.11 & 23.22 & 24.68 & 22.91 & 22.31 & 22.84 & 22.61 & 22.84 & 23.40 & 22.85 & 22.83 & 22.92 \\
\hline $\mathrm{SO}_{3}$ & 0.02 & 0.00 & 0.06 & 0.08 & 0.05 & 0.00 & 0.00 & 0.00 & 0.02 & 0.00 & 0.03 & 0.00 & 0.02 & 0.00 \\
\hline $\mathrm{TiO}_{2}$ & 0.18 & 0.09 & 0.34 & 0.55 & 0.52 & 0.18 & 0.11 & 0.11 & 0.08 & 0.14 & 0.05 & 0.12 & 0.05 & 0.07 \\
\hline $\mathrm{Cl}$ & 0.01 & 0.01 & 0.00 & 0.02 & 0.02 & 0.01 & 0.00 & 0.00 & 0.01 & 0.01 & 0.01 & 0.01 & 0.00 & 0.01 \\
\hline $\mathrm{F}$ & 2.88 & 3.34 & 3.10 & 2.78 & 2.96 & 3.21 & 3.06 & 2.54 & 2.70 & 2.08 & 3.19 & 2.75 & 2.93 & 2.76 \\
\hline $\mathrm{H}_{2} \mathrm{O}^{*}$ & 23.27 & 23.41 & 23.86 & 23.16 & 23.35 & 23.13 & 23.05 & 23.33 & 23.25 & 23.29 & 23.05 & 23.31 & 22.91 & 23.36 \\
\hline $\mathrm{O}=\mathrm{F}, \mathrm{Cl}$ & -1.21 & -1.40 & -1.31 & -1.17 & -1.25 & -1.35 & -1.29 & -1.07 & -1.14 & -0.88 & -1.34 & -1.16 & -1.24 & -1.16 \\
\hline total & 105.82 & 108.69 & 110.68 & 103.07 & 108.69 & 104.12 & 103.81 & 104.34 & 103.84 & 106.82 & 106.01 & 104.34 & 105.83 & 105.31 \\
\hline $\mathrm{Na}^{+}$ & 0.022 & 0.015 & 0.021 & 0.039 & 0.017 & 0.034 & 0.017 & 0.032 & 0.043 & 0.014 & 0.003 & $3 \quad 0.000$ & 0.026 & 0.031 \\
\hline $\mathrm{K}^{+}$ & 0.042 & 0.036 & 0.037 & 0.070 & 0.034 & 0.043 & 0.033 & 0.058 & 0.063 & 0.022 & 0.034 & 0.058 & 0.021 & 0.034 \\
\hline $\mathrm{Ca}^{2+}$ & 2.232 & 1.846 & 1.827 & 2.094 & 1.990 & 2.566 & 2.503 & 2.471 & 2.459 & 2.080 & 2.081 & 2.490 & 2.113 & 2.531 \\
\hline $\mathrm{Ba}^{2+}$ & 0.006 & 0.017 & 0.000 & 0.000 & 0.006 & 0.006 & 0.000 & 0.019 & 0.000 & 0.000 & 0.003 & 0.016 & 0.003 & 0.008 \\
\hline $\mathrm{Sr}^{2+}$ & 0.364 & 0.722 & 0.546 & 0.509 & 0.614 & 0.063 & 0.087 & 0.168 & 0.253 & 0.543 & 0.378 & 0.220 & 0.510 & 0.100 \\
\hline $\mathrm{Pb}^{2+}$ & 0.002 & 0.007 & 0.000 & 0.013 & 0.005 & 0.002 & 0.000 & 0.001 & 0.002 & 0.000 & 0.000 & 0.000 & 0.000 & 0.000 \\
\hline $\mathrm{Mn}^{2+}$ & 0.008 & 0.019 & 0.009 & 0.010 & 0.008 & 0.010 & 0.011 & 0.012 & 0.006 & 0.004 & 0.004 & 0.009 & 0.000 & 0.000 \\
\hline $\mathrm{Zn}^{2+}$ & 0.043 & 0.102 & 0.064 & 0.090 & 0.045 & 0.056 & 0.068 & 0.006 & 0.011 & 0.029 & 0.038 & 0.022 & 0.008 & 0.021 \\
\hline $\mathrm{Al}^{3+}$ & 7.275 & 7.390 & 7.491 & 7.309 & 7.298 & 7.253 & 7.357 & 7.141 & 7.215 & 7.166 & 7.263 & 7.271 & 7.152 & 7.255 \\
\hline $\mathrm{Fe}^{3+}$ & 0.059 & 0.163 & 0.070 & 0.053 & 0.060 & 0.032 & 0.039 & 0.012 & 0.008 & 0.223 & 0.084 & 0.001 & 0.007 & 0.008 \\
\hline $\mathrm{Ti}^{4+}$ & 0.028 & 0.014 & 0.050 & 0.090 & 0.078 & 0.028 & 0.017 & 0.017 & 0.013 & 0.021 & 0.007 & 0.019 & 0.007 & 0.010 \\
\hline $\mathrm{Si}^{4+}$ & 2.602 & 2.110 & 2.135 & 2.381 & 2.426 & 2.699 & 2.718 & 2.859 & 2.773 & 2.677 & 2.644 & 2.715 & 2.898 & 2.812 \\
\hline $\mathrm{As}^{5+}$ & 0.005 & 0.018 & 0.000 & 0.003 & 0.000 & 0.009 & 0.000 & 0.000 & 0.007 & 0.015 & 0.009 & 0.000 & 0.003 & 0.000 \\
\hline $\mathrm{P}^{5+}$ & 4.057 & 4.320 & 4.295 & 4.242 & 4.209 & 4.007 & 3.886 & 3.987 & 3.995 & 3.919 & 3.995 & 4.012 & 3.937 & 3.925 \\
\hline $\mathrm{S}^{6+}$ & 0.003 & 0.000 & 0.009 & 0.013 & 0.007 & 0.000 & 0.000 & 0.000 & 0.003 & 0.000 & 0.005 & 0.000 & 0.003 & 0.000 \\
\hline $\mathrm{Cl}^{-}$ & 0.003 & 0.002 & 0.000 & 0.008 & 0.005 & 0.005 & 0.001 & 0.000 & 0.005 & 0.002 & 0.003 & 0.002 & 0.000 & 0.002 \\
\hline $\mathrm{F}^{-}$ & 1.861 & 2.151 & 1.905 & 1.898 & 1.885 & 2.100 & 1.991 & 1.653 & 1.782 & 1.335 & 2.035 & 1.806 & 1.890 & 1.763 \\
\hline $\mathrm{H}^{+}$ & 33.968 & 35.007 & 34.616 & 34.744 & 34.477 & 33.617 & 33.238 & 33.819 & 33.980 & 33.866 & 33.271 & 34.031 & 33.327 & 33.559 \\
\hline $\mathrm{OH}$ & 0.964 & 2.000 & 1.619 & 1.749 & 1.474 & 0.620 & 0.241 & 0.824 & 0.972 & 0.863 & 0.274 & 1.027 & 0.326 & 0.553 \\
\hline $\mathrm{H}_{2} \mathrm{O}$ & 16.502 & 16.504 & 16.499 & 16.497 & 16.501 & 16.499 & 16.499 & 16.497 & 16.504 & 16.501 & 16.498 & 16.502 & 16.500 & 16.503 \\
\hline
\end{tabular}

mean and 1-13 spot analyses of $\boldsymbol{U N K \boldsymbol { I }}$

$\mathrm{H}_{2} \mathrm{O}^{*}$ content was calculated from the general formula $\left(\mathrm{H}_{2} \mathrm{O}=16.50\right)$ and charge balance; empirical formulas were calculated on the basis of $(\mathrm{P}+\mathrm{As}+\mathrm{Si}+\mathrm{S}+\mathrm{Al}+\mathrm{Fe}+\mathrm{Ti})=14$.

in $\boldsymbol{U N K} \mathbf{1}$ is filled by dominant $\mathrm{Al}$ and minor Ti (max. 0.09 apfu) and $\mathrm{Fe}(0.22$ apfu) (Fig. 7). With regard to the high occupancy of the $B$-site (7.17-7.61 apfu) it is probable that a part of $\mathrm{Al}(0.17-0.61 a p f u)$ substitutes for $\mathrm{Si}$ in the $T_{(1)}$-site (Mills et al. 2004) and the $B$-site contains 6.76-6.99 apfu Al.

The tetrahedral $T_{(1)}$-site in $\boldsymbol{U N K \boldsymbol { 1 }}$ is occupied by $\mathrm{Si}$ (2.11-2.90 apfu) and probably by a part of Al (0.17-0.61 $a p f u$ ). The occupancy of the site ranges from 2.68 to 3.13 $a p f u$. In the second tetrahedral $T_{(2)}$-site, phosphorus is the dominant element (3.89-4.32 apfu), while the contents of $\mathrm{S}$ and As are minor (to 0.01, $0.02 \mathrm{apfu}$, respectively). The total occupancy of the site is 3.89-4.34 apfu. Data in Fig. 8 suggest that in some analyses $\mathrm{P}$ may partly enter the $T_{(1)}$-site or they may indicate deviations in the ratio of $T_{(1)}: T_{(2)}$ from the theoretical value of $3: 4$ (see dis- order domains in the crystal structure of perhamite, Mills et al. 2004).

The $X$-site in $\boldsymbol{U N K} \boldsymbol{1}$, in difference from the data for perhamite (Dunn - Appleman 1977), contains significant F corresponding to 1.34-2.15 apfu. Low and variable $\mathrm{Cl}$ is below 0.01 apfu and $(\mathrm{OH})$ content calculated by difference corresponds to 0.24-2.00 apfu. The total occupancy of the $X$-site varies in dependence on charge balance for individual analyses from 2.20 to 4.15 apfu. All analyses of $\boldsymbol{U N K} \mathbf{1}$ indicate that fluorine is the dominant element in the $X$-site (Fig. 9). The empirical formula for UNK1, derived from the mean of 13 spot analyses on the basis of $(\mathrm{P}+\mathrm{As}+\mathrm{Si}+\mathrm{S}+\mathrm{Al}+\mathrm{Fe}+\mathrm{Ti})=14$ and the above assumptions, is $\left(\mathrm{Ca}_{2.23} \mathrm{Sr}_{0.36} \mathrm{Zn}_{0.04} \mathrm{~K}_{0.04} \mathrm{Na}_{0.02} \mathrm{Ba}_{0.01} \mathrm{Mn}_{0.01}\right)_{\Sigma 2.71}$ $\left(\mathrm{Al}_{6.91} \mathrm{Fe}_{0.06} \mathrm{Ti}_{0.03}\right)_{\Sigma 7.00}\left[\left(\mathrm{Si}_{2.60} \mathrm{Al}_{0.36}\right) \mathrm{O}_{4}\right]_{\Sigma 2.96}\left[\left(\mathrm{PO}_{4}\right)_{4.06}\left(\mathrm{AsO}_{4}\right)_{0.01}\right]_{\Sigma 4.07}$ $\left[\mathrm{F}_{1.86}(\mathrm{OH})_{0.96}\right]_{\Sigma 2.83} \cdot 16.5 \mathrm{H}_{2} \mathrm{O}$. 


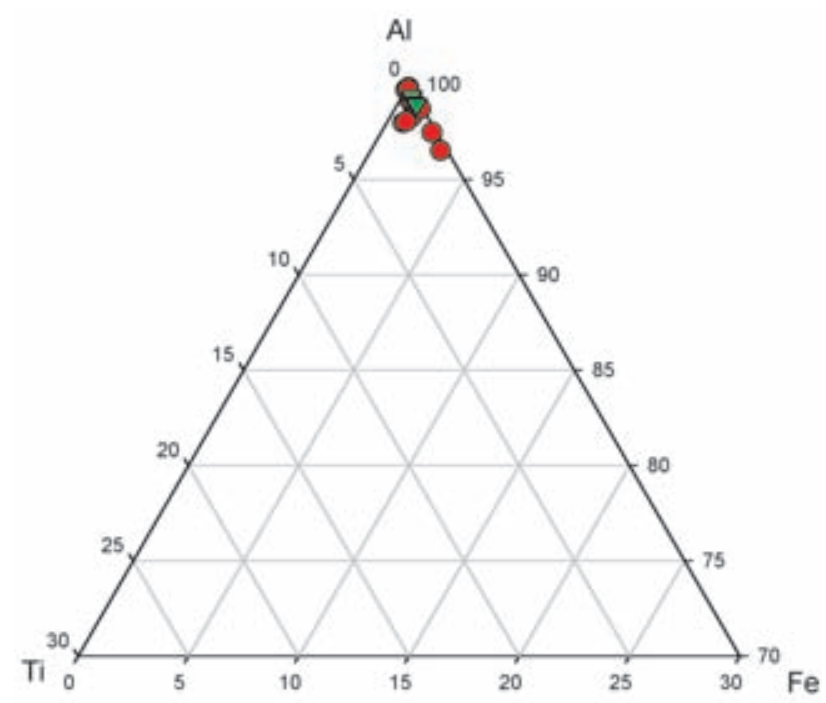

UNK1, Krásno (this paper)

$\nabla$ perhamite, Newry Hill (Dunn - Appleman 1977)

Fig. 7 Part of ternary plot Al (in $B$-site)-Ti-Fe of the $B$-site occupancy (atomic ratios) for $\boldsymbol{U N K} \mathbf{1}$ from Krásno.

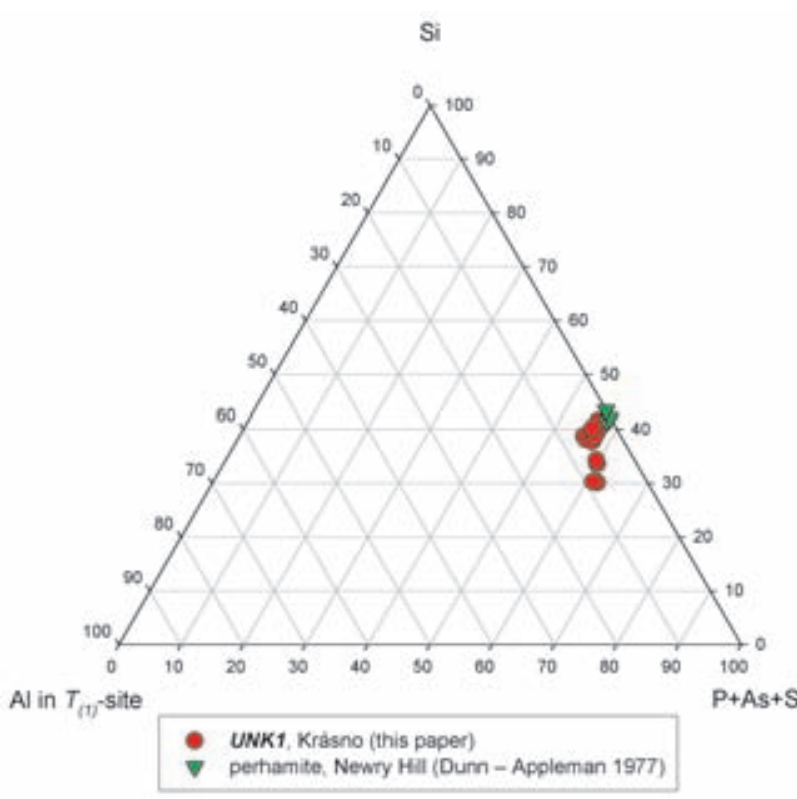

Fig. 8 Ternary plot $\mathrm{Si}-\mathrm{Al}$ in $T_{(I)}$-site- $(\mathrm{P}+\mathrm{As}+\mathrm{S})$ of $T$-sites occupancy (atomic ratios) for $\boldsymbol{U N K} \mathbf{1}$ from Krásno.

\section{UNK2 $\mathrm{Cu}$ arsenate $-\mathrm{Cu}_{13}\left(\mathrm{AsO}_{4}\right)_{6}\left(\mathrm{AsO}_{3} \mathrm{OH}\right)_{4} \cdot 23 \mathrm{H}_{2} \mathrm{O}$ (IMA 2004-38)}

The phase $\boldsymbol{U N K} \mathbf{2}$ has been found in the Huber open pit. It occurred in proximity of a narrow and weathered ore vein, carrying tennantite and cuprite in its centre. The phase $\boldsymbol{U N K} 2$ forms light blue to light blue-green crystalline coatings up to 2 by $2 \mathrm{~cm}$ in size, which are composed of minute and imperfect thin tabular crystals (Fig. 10). It also occurs in a mixture with clay minerals

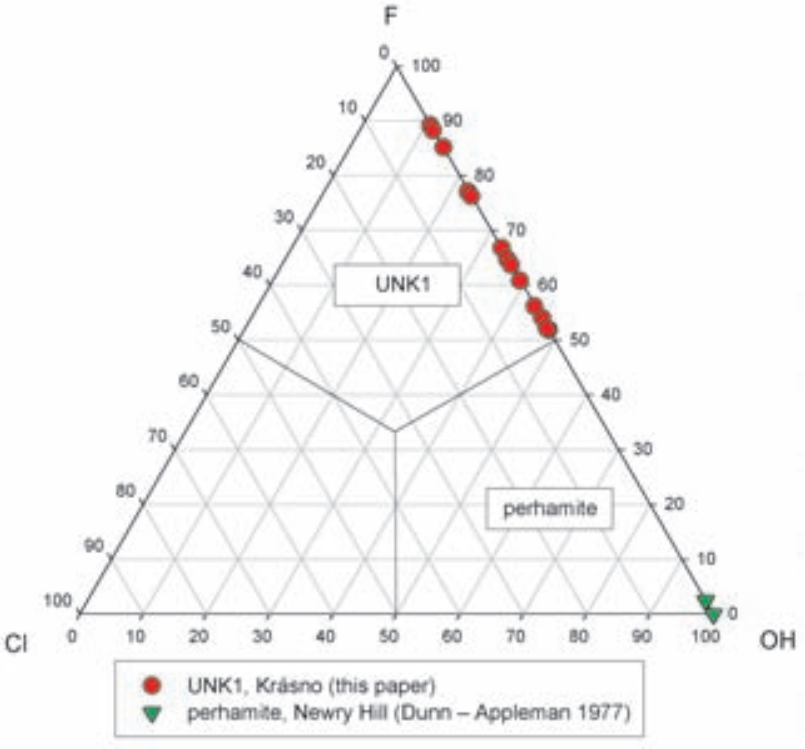

Fig. 9 Ternary plot F-Cl-(OH) of $X$-sites occupancy (atomic ratios) for UNK1 from Krásno.

as light blue aggregates cementing weathered gangue, or as botryoidal aggregates in weathered greisen around the ore vein, reminiscent of chalcanthite efflorescence. X-ray amorphous arsenates of $\mathrm{Cu}$ and $\mathrm{Fe}$ in green glassy aggregates cementing gangue are closely associated with UNK2.

The X-ray powder diffraction data (Table 4) and refined unit-cell parameters for $\boldsymbol{U N K 2}$ from Krásno (Table 5) correspond to a recently studied new mineral from the Geschieber vein in the Jáchymov ore district (Krušné hory, Czech Republic). The samples from Jáchymov contain well-formed crystals. Results of a detailed study of this material, including determination of crystal structure based on single-crystal X-ray diffraction and quantitative chemical analysis, were submitted to the Com-

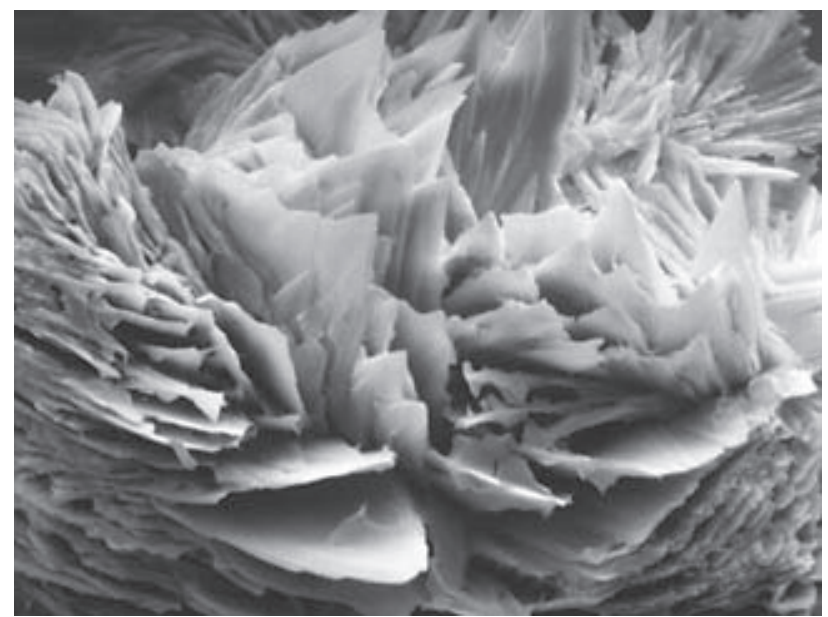

Fig. 10 Group of thin tabular crystals of $\boldsymbol{U N K}$ 2, Krásno. Width of the area shown $80 \mu \mathrm{m}$. SEM photograph Tesla BS 340, A. Gabašová. 
Table 4 X-ray powder diffraction pattern of $\boldsymbol{U N K \boldsymbol { 2 }}$

\begin{tabular}{|c|c|c|c|c|c|c|c|c|c|c|c|c|c|c|}
\hline$I_{r e l}$ & $d$ & $h$ & $k$ & $l$ & $I_{r e l}$ & $d$ & $h$ & $k$ & $l$ & $I_{r e l}$ & $d$ & $h$ & $k$ & $l$ \\
\hline 2.7 & 15.775 & 0 & 0 & 1 & 0.2 & 3.120 & 1 & 3 & 1 & 0.4 & 2.2701 & 0 & 2 & 6 \\
\hline 2.1 & 13.778 & 0 & 1 & 0 & 1.1 & 3.097 & 0 & 2 & 4 & 0.2 & 2.2660 & 0 & -3 & 7 \\
\hline 100.0 & 12.015 & 0 & -1 & 1 & 0.6 & 3.089 & 0 & 3 & 3 & 0.2 & 2.2399 & 2 & 3 & 1 \\
\hline 0.6 & 9.266 & 0 & 1 & 1 & 0.5 & 3.048 & 2 & -2 & 0 & 0.5 & 2.2229 & -1 & 6 & 1 \\
\hline 1.8 & 7.006 & 0 & -2 & 1 & 0.3 & 2.996 & -2 & -1 & 1 & 0.2 & 2.1996 & 1 & 4 & 3 \\
\hline 3.4 & 6.889 & 0 & 2 & 0 & 0.3 & 2.992 & 2 & -1 & 1 & 0.2 & 2.1687 & -2 & 5 & 2 \\
\hline 1.8 & 6.195 & 0 & 1 & 2 & 1.2 & 2.989 & -2 & -1 & 2 & 0.3 & 2.1580 & 1 & -6 & 4 \\
\hline 0.5 & 6.183 & 1 & 0 & 0 & 0.9 & 2.982 & 0 & -3 & 5 & 0.2 & 2.1561 & 0 & -4 & 7 \\
\hline 0.2 & 6.095 & 1 & -1 & 0 & 0.7 & 2.962 & 1 & -4 & 3 & 0.2 & 2.1403 & -2 & 4 & 4 \\
\hline 3.0 & 6.008 & 0 & -2 & 2 & 0.5 & 2.958 & 1 & -3 & 4 & 0.3 & 2.1384 & 0 & 1 & 7 \\
\hline 3.6 & 5.792 & 0 & 2 & 1 & 0.9 & 2.935 & 2 & -2 & 1 & 0.2 & 2.1019 & -2 & -3 & 6 \\
\hline 0.4 & 5.504 & -1 & -1 & 1 & 0.9 & 2.917 & 0 & 1 & 5 & 0.2 & 2.0998 & -1 & -5 & 6 \\
\hline 0.3 & 5.365 & 1 & 0 & 1 & 0.4 & 2.905 & -1 & -4 & 1 & 0.2 & 2.0976 & -1 & -4 & 7 \\
\hline 0.3 & 5.276 & 1 & 1 & 0 & 1.2 & 2.896 & 0 & 4 & 2 & 0.2 & 2.0961 & 2 & 3 & 2 \\
\hline 0.4 & 5.258 & 0 & 0 & 3 & 0.2 & 2.880 & -2 & -1 & 3 & 0.2 & 2.0919 & -1 & 5 & 4 \\
\hline 0.3 & 5.121 & -1 & -1 & 2 & 1.9 & 2.841 & 0 & -5 & 1 & 0.2 & 2.0671 & 0 & 6 & 2 \\
\hline 0.7 & 5.093 & -1 & 1 & 2 & 0.5 & 2.838 & 0 & -5 & 2 & 0.2 & 2.0357 & 1 & -6 & 5 \\
\hline 0.3 & 4.858 & -1 & 2 & 1 & 0.3 & 2.812 & 1 & 3 & 2 & 0.3 & 2.0292 & 1 & 6 & 0 \\
\hline 1.0 & 4.748 & 0 & -3 & 1 & 0.2 & 2.795 & 1 & 1 & 4 & 0.4 & 2.0278 & 0 & 5 & 4 \\
\hline 1.4 & 4.633 & 0 & 2 & 2 & 0.2 & 2.762 & 2 & -3 & 1 & 0.3 & 2.0213 & 0 & -7 & 3 \\
\hline 0.2 & 4.618 & 1 & 1 & 1 & 0.5 & 2.752 & -2 & -2 & 2 & 0.4 & 2.0206 & 1 & -7 & 2 \\
\hline 0.2 & 4.592 & 1 & -1 & 2 & 0.7 & 2.751 & 1 & -5 & 1 & 0.3 & 2.0162 & 0 & -5 & 7 \\
\hline 0.4 & 4.540 & 0 & 1 & 3 & 0.7 & 2.748 & 0 & -5 & 3 & 0.2 & 2.0098 & 2 & 4 & 1 \\
\hline 0.3 & 4.281 & -1 & 2 & 2 & 0.2 & 2.746 & 2 & -2 & 2 & 0.2 & 2.0047 & 1 & 4 & 4 \\
\hline 0.2 & 4.217 & 1 & 2 & 0 & 0.7 & 2.702 & -2 & 3 & 2 & 0.2 & 2.0015 & -1 & -6 & 5 \\
\hline 0.3 & 4.134 & 0 & 3 & 1 & 0.2 & 2.702 & 1 & -5 & 2 & 0.3 & 1.9960 & 0 & 2 & 7 \\
\hline 0.4 & 4.030 & 1 & -3 & 1 & 0.2 & 2.698 & 0 & -2 & 6 & 0.2 & 1.9959 & -1 & -3 & 8 \\
\hline 0.3 & 3.937 & -1 & -2 & 3 & 0.6 & 2.689 & -2 & -2 & 3 & 0.2 & 1.9854 & -1 & 6 & 3 \\
\hline 0.3 & 3.876 & -1 & 3 & 1 & 0.4 & 2.629 & 0 & 0 & 6 & 0.2 & 1.9719 & 0 & 0 & 8 \\
\hline 0.4 & 3.792 & 1 & 2 & 1 & 0.3 & 2.624 & 2 & -3 & 2 & 0.2 & 1.9682 & 0 & 7 & 0 \\
\hline 0.2 & 3.723 & -1 & 0 & 4 & 0.2 & 2.612 & -1 & 5 & 1 & 0.3 & 1.9561 & 2 & -6 & 3 \\
\hline 0.2 & 3.626 & 1 & 0 & 3 & 0.8 & 2.604 & 0 & 5 & 1 & 0.3 & 1.9384 & -2 & 5 & 4 \\
\hline 0.7 & 3.589 & 0 & 3 & 2 & 0.5 & 2.560 & -2 & -2 & 4 & 0.3 & 1.9380 & -1 & 4 & 6 \\
\hline 0.5 & 3.548 & -1 & -3 & 1 & 0.4 & 2.546 & -2 & 2 & 4 & 0.2 & 1.9271 & 1 & -7 & 4 \\
\hline 1.0 & 3.539 & -1 & -3 & 2 & 0.5 & 2.540 & -2 & 3 & 3 & 0.2 & 1.9120 & -2 & 2 & 7 \\
\hline 0.2 & 3.463 & 0 & -3 & 4 & 0.2 & 2.514 & 1 & 3 & 3 & 0.2 & 1.9107 & 3 & -4 & 1 \\
\hline 3.4 & 3.444 & 0 & 4 & 0 & 0.2 & 2.505 & -2 & 0 & 5 & 0.6 & 1.9066 & -1 & -6 & 6 \\
\hline 0.5 & 3.389 & 1 & 3 & 0 & 0.3 & 2.4875 & 2 & 2 & 1 & 0.2 & 1.8852 & 2 & 5 & 0 \\
\hline 0.3 & 3.365 & -1 & -3 & 3 & 0.2 & 2.4556 & -1 & 5 & 2 & 0.4 & 1.8611 & -1 & -7 & 3 \\
\hline 0.2 & 3.358 & 1 & -3 & 3 & 0.2 & 2.4395 & -1 & -5 & 1 & 0.3 & 1.8533 & 0 & 5 & 5 \\
\hline 2.3 & 3.294 & 0 & -4 & 3 & 0.3 & 2.4380 & 2 & 0 & 3 & 0.2 & 1.8371 & 2 & -7 & 1 \\
\hline 0.9 & 3.281 & 1 & 1 & 3 & 0.7 & 2.4202 & 1 & -5 & 4 & 0.3 & 1.8295 & -1 & -7 & 1 \\
\hline 0.8 & 3.263 & 0 & -1 & 5 & 1.1 & 2.4090 & 0 & -4 & 6 & 0.2 & 1.8268 & 2 & -7 & 0 \\
\hline 1.0 & 3.199 & 0 & 4 & 1 & 0.3 & 2.4031 & 0 & -5 & 5 & 0.2 & 1.7944 & 0 & 6 & 4 \\
\hline 0.2 & 3.195 & 0 & -2 & 5 & 0.8 & 2.3742 & 0 & -6 & 2 & 0.4 & 1.7794 & 1 & 7 & 0 \\
\hline 0.2 & 3.170 & -2 & 0 & 1 & 0.2 & 2.3624 & -1 & -5 & 4 & 0.2 & 1.7764 & 2 & 4 & 3 \\
\hline 0.3 & 3.161 & 1 & -1 & 4 & 0.2 & 2.3545 & 1 & 5 & 0 & 0.2 & 1.7739 & -2 & -6 & 2 \\
\hline 0.7 & 3.155 & 0 & 0 & 5 & 0.4 & 2.3359 & 0 & 3 & 5 & 0.2 & 1.7433 & -2 & -6 & 1 \\
\hline 0.4 & 3.149 & 2 & -1 & 0 & 0.2 & 2.3207 & 1 & -6 & 2 & 0.3 & 1.7126 & 1 & 7 & 1 \\
\hline 0.2 & 3.142 & -1 & 4 & 1 & 0.5 & 2.3092 & 2 & 2 & 2 & 0.3 & 1.7062 & -3 & -4 & 2 \\
\hline
\end{tabular}

Tab1e 5 Unit-cell parameters of $\boldsymbol{U N K} \boldsymbol{2}$ (for triclinic space group $P$-1)

\begin{tabular}{|l|cc|}
\hline & $\begin{array}{c}\text { Krásno } \\
\text { this paper }\end{array}$ & $\begin{array}{c}\text { Jáchymov } \\
\text { IMA 2004-038 }\end{array}$ \\
\hline$a[\AA]$ & $6.407(7)$ & $6.408(3)$ \\
$b[\AA]$ & $14.402(7)$ & $14.491(5)$ \\
$c[\AA]$ & $16.60(2)$ & $16.505(8)$ \\
$\alpha\left[^{\circ}\right]$ & $102.89(6)$ & $102.87(3)$ \\
$B\left[^{\circ}\right]$ & $100.5(1)$ & $101.32(5)$ \\
$\gamma\left[^{\circ}\right]$ & $98.23(8)$ & $97.13(3)$ \\
$V\left[\AA^{3}\right]$ & 1441 & $1442(1)$ \\
\hline
\end{tabular}

mission on New Minerals and Mineral Names of the International Mineralogical Association. The proposal was approved by the Commission as a new mineral under the number IMA 2004-38.

The chemical composition of $\boldsymbol{U N K} \mathbf{2}$ from Krásno has been studied with EMPA (energy-dispersion type) only in a semi-quantitative way. $\mathrm{Cu}$ and $\mathrm{As}$ are the major elements. This is in good agreement with the quantitative chemical data for the proposed mineral from Jáchymov, 
which yielded the ideal formula $\mathrm{Cu}_{13}\left(\mathrm{AsO}_{4}\right)_{6}\left(\mathrm{AsO}_{3} \mathrm{OH}\right)_{4}$ . $23 \mathrm{H}_{2} \mathrm{O}$.

\section{UNK3 Zn-Fe phosphate (rockbridgeite-like) - $\mathrm{Zn}(\mathrm{Fe}, \mathrm{Zn}, \mathrm{Al})_{4}\left(\mathrm{PO}_{4}\right)_{3}(\mathrm{OH})_{4}$}

The mineral phase $\boldsymbol{U N K} 3$ has been noted in several samples of phosphate accumulations in the Huber open pit (Sejkora et al. 2006c). Since morphology of $\boldsymbol{U N K} 3$ and its hosting asseblages vary significantly, individual types of occurrence are described separately.
The first type of $\boldsymbol{U N K} \mathbf{3}$ occurs in a $6 \mathrm{~cm}$ long fragment of triplite aggregate, altered to compact red-brown fluorapatite and isokite. This material is accompanied by coarse-grained white quartz containing up to $2 \mathrm{~cm}$ long grains of dark green fluorapatite. Cavities in this material, $1-2 \mathrm{~cm}$ in diameter, carry semi-spherical to spheroidal, radiating aggregates of $\boldsymbol{U N K} 3$ up to $1.5 \mathrm{~mm}$ in size (Fig. 11), locally grouped to aggregates $5 \mathrm{~mm}$ long (Fig. 12). The cavities also carry imperfect crystals of light yellow-grey younger fluorapatite. The aggregates of UNK3 (Fig. 13) are black-green to black with a green

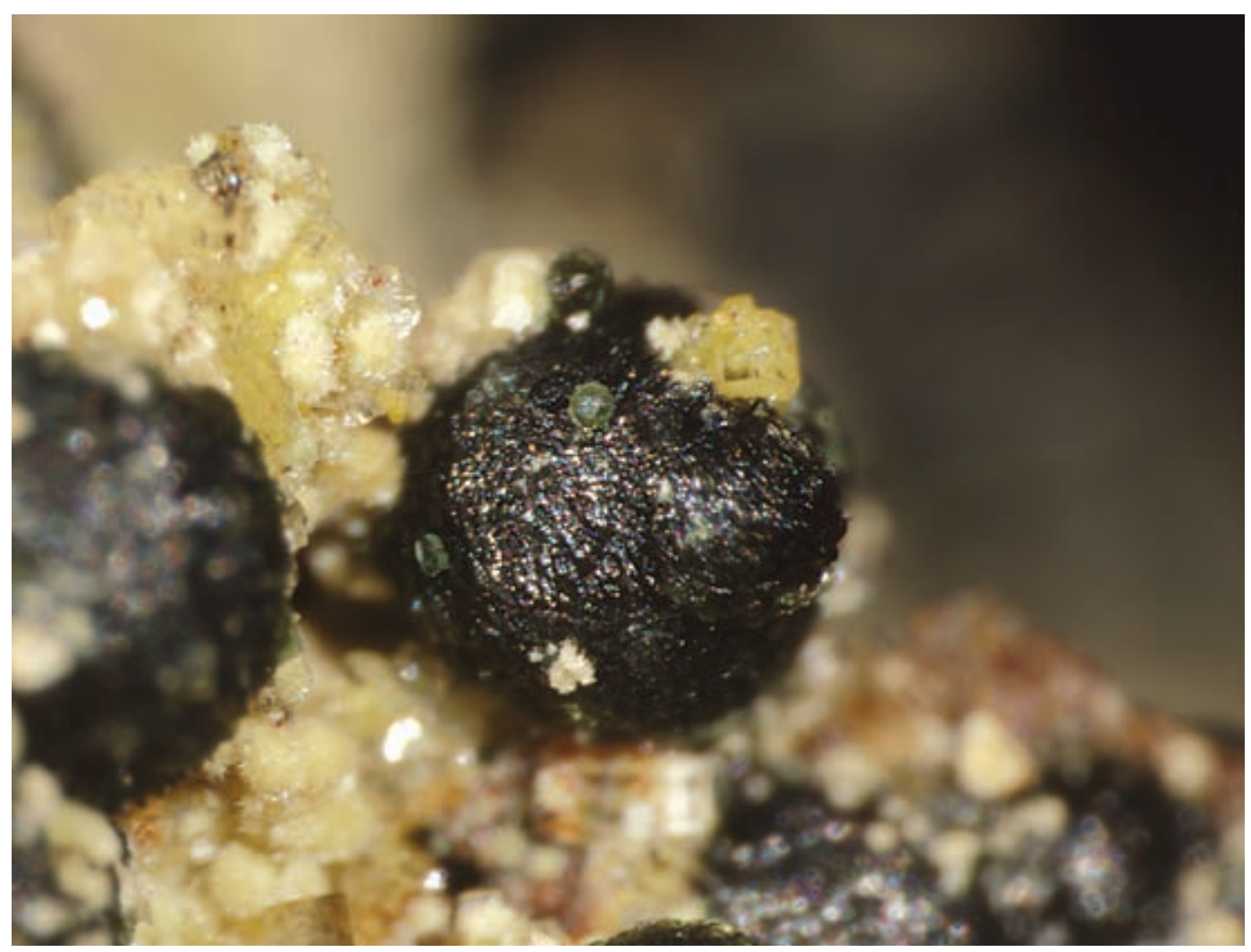

Fig. 11 Black-green spheroidal aggregates of $\boldsymbol{U N K} 3$ with light fluorapatite. Huber open pit, Krásno. Width of the area shown $2.1 \mathrm{~mm}$. Nikon SMZ1500, photograph by J. Sejkora.

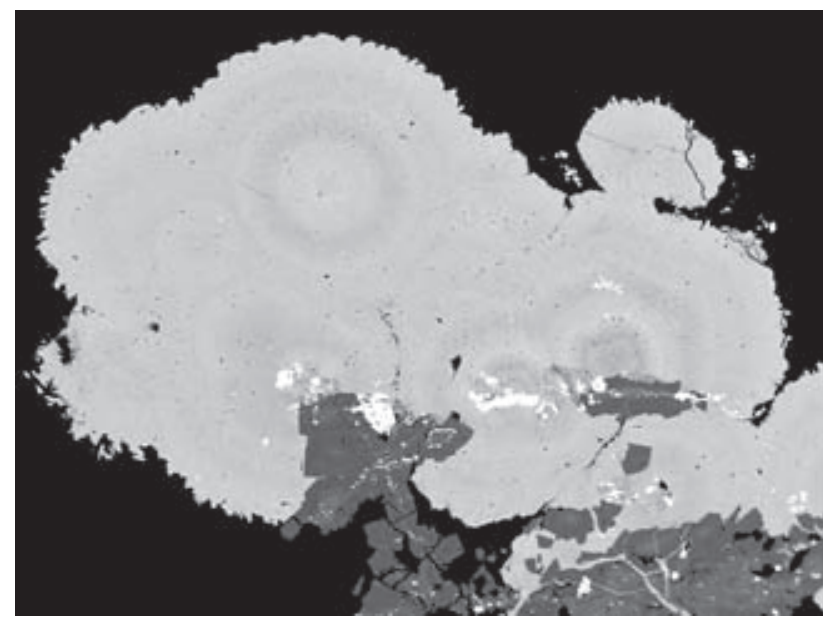

Fig. 12 Semi-spheroidal aggregates of $\boldsymbol{U N K}$, showing a weak zoning, with inclusions of Fe oxides-hydroxides (white) deposited on fluorapatite (dark grey), with minute inclusions of Nb-rutile (light). Width of the area shown $2 \mathrm{~mm}$. Cameca SX100 BSE photograph by J. Sejkora and R. Škoda.

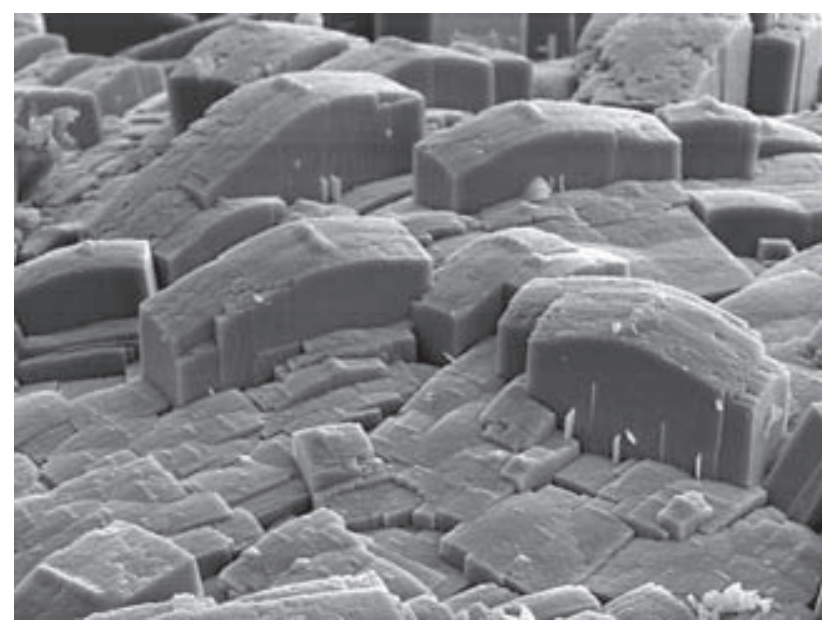

Fig. 13 Detail of surface of spherical aggregates of $\boldsymbol{U N K} \mathbf{3}$ (the first type), Krásno. Width of the area shown $75 \mu \mathrm{m}$. SEM photograph Jeol JSM-6380, J. Sejkora and J. Plášil. 
shade, vitreous on fracture, with a greasy lustre. Minute splinters are transparent, bright green, and have a light grey-green streak.

The second type of $\boldsymbol{U N K} \mathbf{3}$ has been found in strongly altered aggregate of pinkish and white fluorapatite, 7 by $10 \mathrm{~cm}$ in size. The phase forms soft and crumbly greygreen aggregates up to $2 \mathrm{~cm}$ long in irregular cavities 5 by $6 \mathrm{~cm}$ in size. The aggregates consist of minute crystals (to $0.1 \mathrm{~mm}$ ), intergrown with frequent light green fluorapatite and less abundant kolbeckite aggregates. Wellformed tabular crystals of $\boldsymbol{U N K} 3$ (Fig. 14) are black with a green shade, and vitreous lustre.

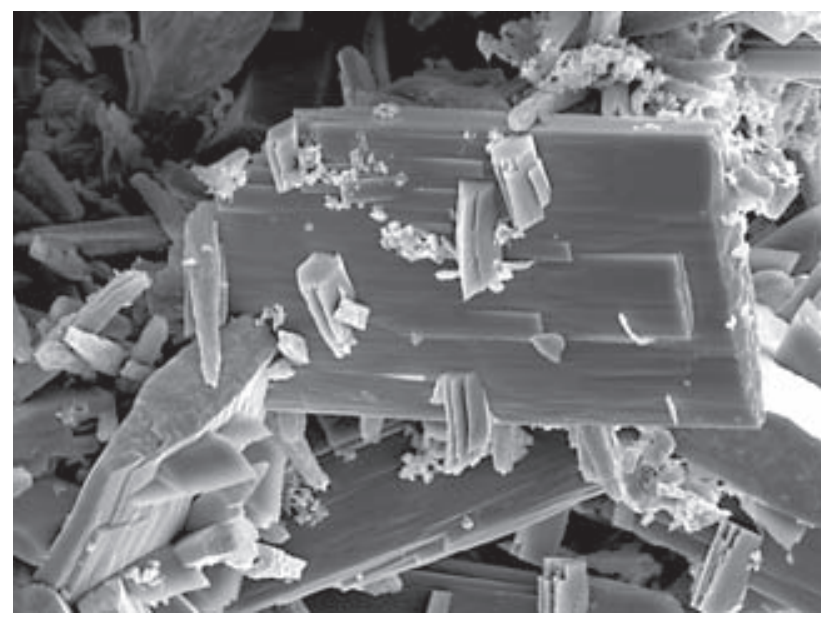

Fig. 14 Tabular crystals of $\boldsymbol{U N K} 3$ (the second type), Krásno. Width of the area shown $80 \mu \mathrm{m}$. SEM photograph Jeol JSM-6380, J. Sejkora and J. Plášil.
The third type of $\boldsymbol{U N K} \mathbf{3}$ has been found in weathered vugs, 2 by $3 \mathrm{~cm}$ in size, in fluorapatite/isokite accumulations with triplite relics. The phase forms dark green crystalline aggregates with a strong vitreous lustre, $0.5-$ $1 \mathrm{~mm}$ in size. The aggregates (Fig. 15) are composed of tabular crystals to $0.1 \mathrm{~mm}$ long, showing occasional rhombic cross-sections. Such aggregates (Fig. 16) are usually overgrown by zoned aggregates of the turquoisegroup minerals, including UNK10, pharmacosiderite, UNK1, rare kolbeckite and Cl-rich fluorapatite. UNK3 of microscopic size occurs in additional two associations of phosphate accumulations: irregular inclusions to

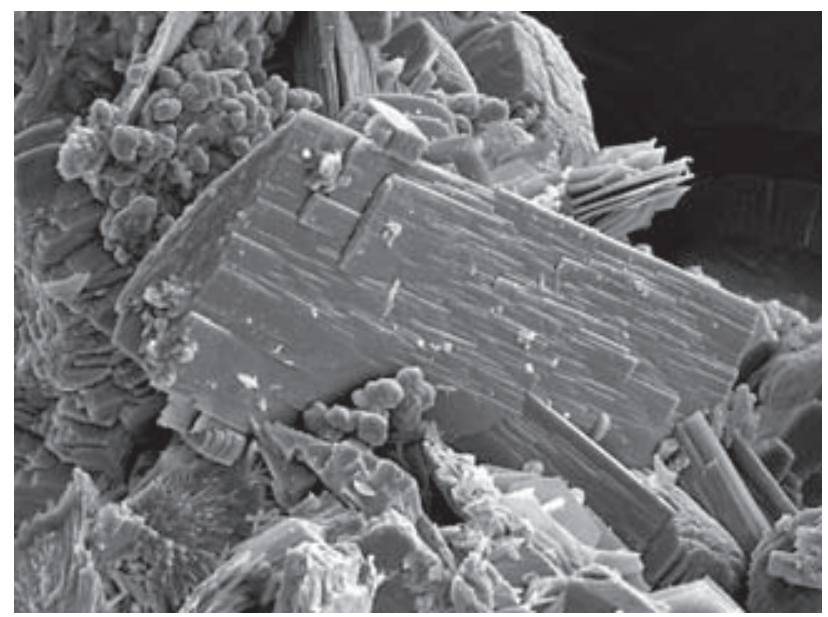

Fig. 15 Tabular crystals of the third type of $\boldsymbol{U N K}$ 3, Krásno. Width of the area shown $110 \mu \mathrm{m}$. SEM photograph Jeol JSM-6380, J. Sejkora and J. Plášil

Fig. 16 Aggregate of tabular crystals of $\boldsymbol{U N K} 3$ (in places with rhombic sections -3 ), overgrown by zoned aggregate of turquoise group minerals $(\mathrm{T})$ and $\boldsymbol{U N K} 1$ (prominently tabular - 1). Pharmacosiderite crystals (light $-\mathrm{P})$ are present at the margin of the aggregate. Width of the area shown $500 \mu \mathrm{m}$. Cameca SX100, BSE photograph by J. Sejkora and R. Škoda.

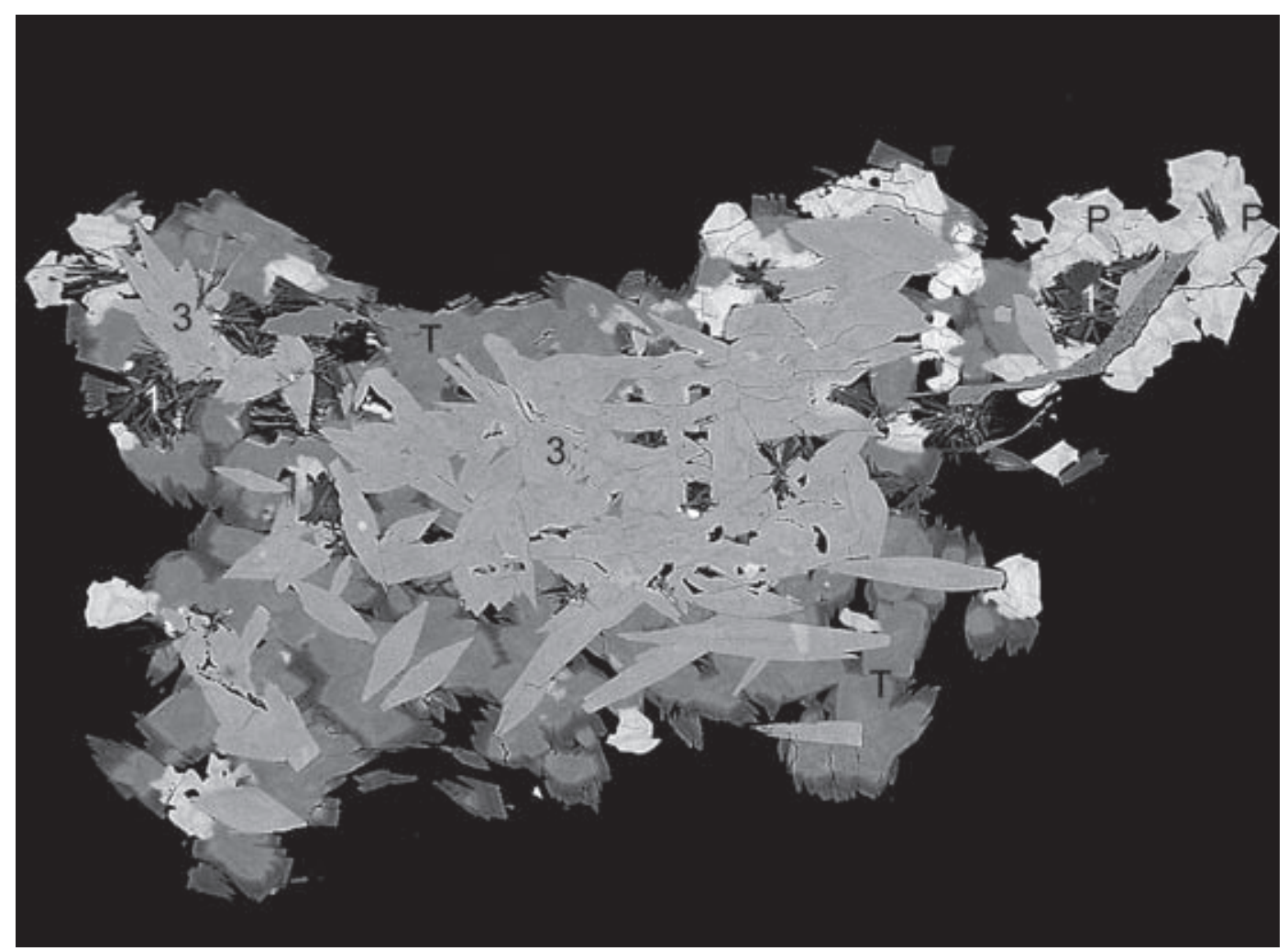


Ta b le 6 X-ray powder diffraction pattern of $\boldsymbol{U N K} \mathbf{3}$

\begin{tabular}{|c|c|c|c|c|c|c|c|c|c|c|c|c|c|c|}
\hline$I_{r e l}$ & $d$ & $h$ & $k$ & $l$ & $I_{\text {rel }}$ & $d$ & $h$ & $k$ & $l$ & $I_{r e l}$ & $d$ & $h$ & $k$ & $l$ \\
\hline 4 & 8.390 & 0 & 0 & 2 & 11 & 2.5790 & 2 & 0 & 0 & 8 & 1.8293 & 2 & 2 & 6 \\
\hline 68 & 6.916 & 0 & 2 & 0 & 20 & 2.4209 & 1 & 1 & 6 & 10 & 1.7950 & 0 & 4 & 8 \\
\hline 10 & 4.824 & 1 & 1 & 0 & 17 & 2.4128 & 1 & 5 & 1 & 14 & 1.7307 & 0 & 8 & 0 \\
\hline 3 & 4.648 & 1 & 1 & 1 & 14 & 2.4011 & 1 & 3 & 5 & 12 & 1.7107 & 1 & 5 & 7 \\
\hline 18 & 4.352 & 0 & 2 & 3 & 4 & 2.3448 & 1 & 5 & 2 & 6 & 1.6961 & 0 & 8 & 2 \\
\hline 40 & 4.195 & 0 & 0 & 4 & 21 & 2.2667 & 0 & 2 & 7 & 9 & 1.6853 & 2 & 6 & 2 \\
\hline 17 & 3.656 & 1 & 1 & 3 & 7 & 2.2242 & 0 & 6 & 2 & 16 & 1.6798 & 0 & 0 & 10 \\
\hline 46 & 3.590 & 0 & 2 & 4 & 3 & 2.1687 & 1 & 3 & 6 & 17 & 1.6420 & 0 & 4 & 9 \\
\hline 19 & 3.438 & 1 & 3 & 0 & 8 & 2.1476 & 1 & 1 & 7 & 11 & 1.6007 & 0 & 8 & 4 \\
\hline 100 & 3.390 & 0 & 4 & 1 & 7 & 2.1080 & 1 & 5 & 4 & 13 & 1.5903 & 2 & 6 & 4 \\
\hline 48 & 3.182 & 1 & 3 & 2 & 3 & 2.0977 & 2 & 2 & 4 & 13 & 1.5526 & 0 & 6 & 8 \\
\hline 25 & 3.021 & 0 & 2 & 5 & 7 & 2.0547 & 2 & 4 & 1 & 6 & 1.5312 & 2 & 6 & 5 \\
\hline 6 & 2.945 & 0 & 4 & 3 & 17 & 2.0221 & 0 & 6 & 4 & 12 & 1.4659 & 2 & 6 & 6 \\
\hline 18 & 2.799 & 0 & 0 & 6 & 11 & 1.9606 & 2 & 2 & 5 & 7 & 1.4583 & 3 & 1 & 6 \\
\hline 20 & 2.755 & 1 & 1 & 5 & 9 & 1.8989 & 2 & 0 & 6 & & & & & \\
\hline 11 & 2.672 & 0 & 4 & 4 & 11 & 1.8465 & 1 & 7 & 0 & & & & & \\
\hline
\end{tabular}

$30 \mu \mathrm{m}$ in beraunite associated with K-poor leucophosphite and irregular aggregates (max. $100 \mu \mathrm{m}$ ) with fluorapatite, isokite, whitmoreite and UNK1.

The X-ray powder diffraction data for the first and second morphological types of $\boldsymbol{U N K} 3$ are practically identical. Detailed work has been done on sample of the first type (Table 6). Since the data are similar to published values for minerals of the series rockbridgeite - frondelite, indexing was done using a model derived from the crystal structure data for rockbridgeite (Moore 1970) (full occupancy of $M(a)$-site $\mathrm{Zn}, M(b)$-sites $\mathrm{Fe}^{3+}$ ). The refined unit-cell parameters for UNK3 (Table 7) are very close to data for rockbridgeite.

The quantitative chemical composition of several morphologically distinct $\boldsymbol{U N K}$ 3 types was obtained on five individual samples. The average of all 19 analyses and eight representative analyses are given in Table 8 . The chemical composition for the morphological types described above is very similar. Since X-ray diffraction data for individual morphological types of $\boldsymbol{U N K} \mathbf{3}$ and minerals of the rockbridgeite-frondelite series are similar, the chemical analyses were re-calculated on the basis of $(\mathrm{P}+\mathrm{As}+\mathrm{Si}+\mathrm{S})$ $=3$ of the general formula $\mathrm{M}(\mathrm{a}) \mathrm{M}(\mathrm{b})_{4}\left(\mathrm{PO}_{4}\right)_{3}(\mathrm{OH})_{5}$. Lower totals of the analyses in the range of 94-97 wt. \%, after inclusion of the theoretical content of $\mathrm{H}_{2} \mathrm{O}$ (corresponding to $\mathrm{OH}$ groups), indicate a possible presence of about 2 water molecules in the phase $\boldsymbol{U N K} \mathbf{3}$.

The chemical composition of $\boldsymbol{U N K} 3$ from Krásno (Table 8 ) is greatly variable and more importantly, represents the highest $\mathrm{Zn}$ content, known at present in minerals related to rockbridgeite - frondelite. In the following text we assume that the $\mathrm{M}^{1+}$ a $\mathrm{M}^{2+}$ cations preferentially occupy $M(a)$ site and $\mathrm{Zn}^{2+}$ surplus (above the total of $M(a)$ site $=1)$ enters the $M(b)$ sites, together with $\mathrm{Fe}^{3+}, \mathrm{Al}^{3+}$ and $\mathrm{Ti}^{4+}$. In addition to minor and irregular contents of $\mathrm{Ba}$ and $\mathrm{Pb}(\max .0 .01 a p f u$ ) in the $M(a)$ site, there are somewhat higher contents of $\mathrm{Ca}(0.02-0.07 \mathrm{apfu}), \mathrm{Mn}$ (0-0.10 apfu), Na (0.01-0.12 apfu) and dominant $\mathrm{Zn}$ in the range of 0.73 to 0.90 apfu (Fig. 17). The $M(b)$ sites (Fig. 18) contain minor and irregular Ti (max. 0.06 apfu),

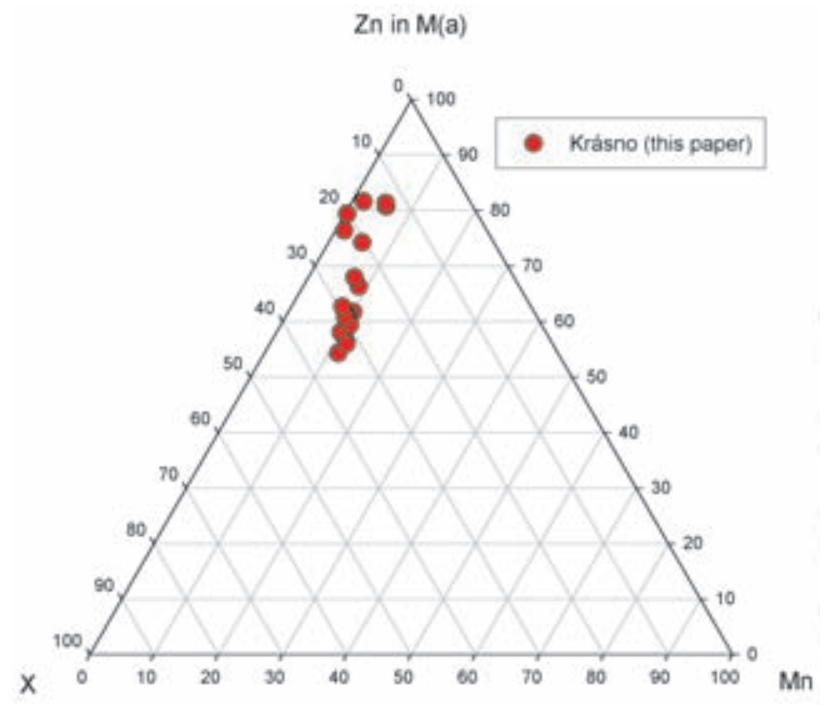

Fig. 17 Ternary plot of Mn-(Zn in M(a))-X of $M(a)$-site occupancy (atomic ratios) for $\boldsymbol{U N K} 3$ from Krásno. $\mathrm{X}=\mathrm{Na}, \mathrm{Ca}, \mathrm{Ba}$ and $\mathrm{Pb}$ in $M(a)$-site.

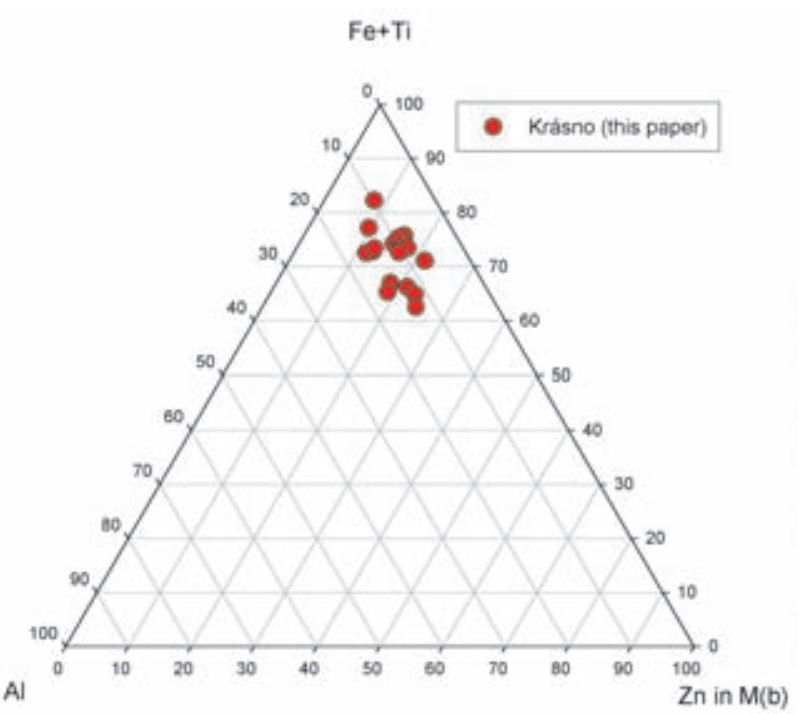

Fig. 18 Ternary plot of $(\mathrm{Zn}$ in $\mathrm{M}(\mathrm{b}))-(\mathrm{Fe}+\mathrm{Ti})-\mathrm{Al}$ of $M(b)$-site occupancy (atomic ratios) for $\boldsymbol{U N K} 3$ from Krásno. 
Table 7 Unit-cell parameters of $\boldsymbol{U N K} \mathbf{3}$ (for orthorhombic space group $\mathrm{Cmcm}$ )

\begin{tabular}{|l|ccc|}
\hline & $\begin{array}{l}\text { UNK3 } \\
\text { this paper }\end{array}$ & $\begin{array}{c}\text { rockbridgeite } \\
1^{*}\end{array}$ & $\begin{array}{c}\text { frondelite } \\
2^{*}\end{array}$ \\
\hline$a[\AA]$ & $5.161(1)$ & $5.172-5.185$ & $5.176-5.210$ \\
$b[\AA]$ & $13.846(2)$ & $13.78-13.873$ & $13.810-13.932$ \\
$c[\AA]$ & $16.789(3)$ & $16.782-16.810$ & $16.811-17.010$ \\
$V\left[\AA^{3}\right]$ & $1199.8(3)$ & $1198.0-1207.1$ & $1211.4-1231.0$ \\
\hline
\end{tabular}

*1 various occurrences, Sejkora et al. (2006c), Moore (1970), ICDD 34-150.

*2 various occurrences, Sejkora et al. (2006c), ICDD 8-83, 35-625.

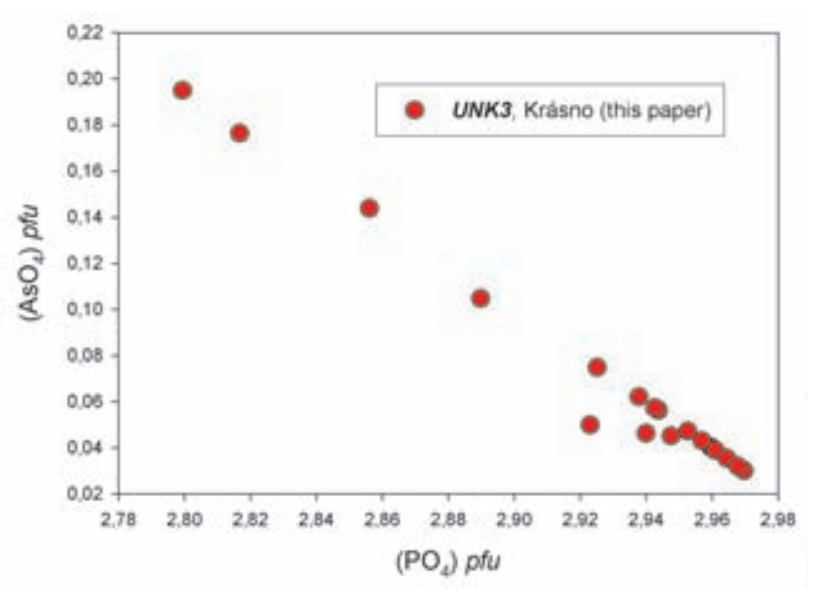

Fig. 19 Plot of $\left(\mathrm{PO}_{4}\right)-\left(\mathrm{AsO}_{4}\right) p f u$ in tetrahedral site of $\boldsymbol{U N K} 3$ from Krásno.

Table 8 Chemical composition of $\boldsymbol{U N K} 3$ (wt. \%)

\begin{tabular}{|c|c|c|c|c|c|c|c|c|c|}
\hline & mean & 1 & 2 & 3 & 4 & 5 & 6 & 7 & 8 \\
\hline $\mathrm{Na}_{2} \mathrm{O}$ & 0.42 & 0.41 & 0.37 & 0.34 & 0.44 & 0.50 & 0.04 & 0.56 & 0.46 \\
\hline $\mathrm{K}_{2} \mathrm{O}$ & 0.02 & 0.03 & 0.00 & 0.04 & 0.00 & 0.03 & 0.01 & 0.01 & 0.04 \\
\hline $\mathrm{CaO}$ & 0.43 & 0.32 & 0.29 & 0.14 & 0.56 & 0.49 & 0.36 & 0.41 & 0.52 \\
\hline $\mathrm{BaO}$ & 0.06 & 0.00 & 0.00 & 0.18 & 0.04 & 0.12 & 0.14 & 0.00 & 0.16 \\
\hline $\mathrm{SrO}$ & 0.02 & 0.05 & 0.00 & 0.04 & 0.00 & 0.01 & 0.03 & 0.03 & 0.06 \\
\hline $\mathrm{MgO}$ & 0.02 & 0.00 & 0.03 & 0.01 & 0.02 & 0.03 & 0.02 & 0.01 & 0.02 \\
\hline $\mathrm{PbO}$ & 0.04 & 0.09 & 0.10 & 0.00 & 0.00 & 0.01 & 0.00 & 0.00 & 0.10 \\
\hline $\mathrm{CuO}$ & 0.01 & 0.00 & 0.00 & 0.06 & 0.00 & 0.00 & 0.00 & 0.00 & 0.00 \\
\hline $\mathrm{MnO}$ & 0.72 & 0.77 & 0.45 & 0.14 & 1.01 & 0.86 & 0.47 & 1.11 & 0.73 \\
\hline $\mathrm{ZnO}$ & 15.24 & 10.77 & 12.13 & 13.50 & 15.63 & 17.43 & 17.57 & 18.10 & 19.19 \\
\hline $\mathrm{Al}_{2} \mathrm{O}_{3}$ & 3.71 & 3.07 & 4.13 & 5.05 & 2.88 & 4.01 & 5.08 & 3.93 & 4.17 \\
\hline $\mathrm{Fe}_{2} \mathrm{O}_{3}$ & 36.21 & 39.84 & 37.68 & 35.99 & 37.62 & 32.63 & 32.09 & 32.86 & 30.77 \\
\hline $\mathrm{SiO}_{2}$ & 0.05 & 0.01 & 0.05 & 0.05 & 0.02 & 0.03 & 0.00 & 0.01 & 0.04 \\
\hline $\mathrm{TiO}_{2}$ & 0.20 & 0.70 & 0.34 & 0.10 & 0.01 & 0.68 & 0.22 & 0.52 & 0.74 \\
\hline $\mathrm{As}_{2} \mathrm{O}_{5}$ & 1.22 & 1.31 & 1.82 & 3.36 & 0.72 & 1.14 & 0.77 & 1.01 & 0.86 \\
\hline $\mathrm{P}_{2} \mathrm{O}_{5}$ & 32.15 & 31.58 & 30.97 & 29.76 & 32.96 & 33.19 & 32.75 & 31.93 & 33.26 \\
\hline $\mathrm{SO}_{3}$ & 0.03 & 0.05 & 0.20 & 0.03 & 0.00 & 0.00 & 0.07 & 0.00 & 0.00 \\
\hline $\mathrm{Cl}$ & 0.01 & 0.00 & 0.00 & 0.00 & 0.00 & 0.01 & 0.01 & 0.01 & 0.01 \\
\hline $\mathrm{H}_{2} \mathrm{O}^{*}$ & 5.59 & 5.90 & 5.81 & 5.95 & 5.57 & 4.97 & 5.15 & 5.63 & 4.85 \\
\hline total & 96.14 & 94.88 & 94.36 & 94.72 & 97.48 & 96.13 & 94.78 & 96.12 & 96.00 \\
\hline $\mathrm{Na}^{+}$ & 0.088 & 0.086 & 0.078 & 0.074 & 0.091 & 0.101 & 0.009 & 0.118 & 0.094 \\
\hline $\mathrm{K}^{+}$ & 0.002 & 0.005 & 0.000 & 0.006 & 0.000 & 0.004 & 0.001 & 0.002 & 0.006 \\
\hline $\mathrm{Ca}^{2+}$ & 0.049 & 0.037 & 0.035 & 0.016 & 0.064 & 0.055 & 0.041 & 0.048 & 0.059 \\
\hline $\mathrm{Ba}^{2+}$ & 0.002 & 0.000 & 0.000 & 0.008 & 0.002 & 0.005 & 0.006 & 0.000 & 0.007 \\
\hline $\mathrm{Sr}^{2+}$ & 0.001 & 0.003 & 0.000 & 0.002 & 0.000 & 0.001 & 0.002 & 0.002 & 0.004 \\
\hline $\mathrm{Mg}^{2+}$ & 0.003 & 0.000 & 0.005 & 0.001 & 0.003 & 0.004 & 0.003 & 0.002 & 0.003 \\
\hline $\mathrm{Pb}^{2+}$ & 0.001 & 0.003 & 0.003 & 0.000 & 0.000 & 0.000 & 0.000 & 0.000 & 0.003 \\
\hline $\mathrm{Cu}^{2+}$ & 0.001 & 0.000 & 0.000 & 0.005 & 0.000 & 0.000 & 0.000 & 0.000 & 0.000 \\
\hline $\mathrm{Mn}^{2+}$ & 0.065 & 0.072 & 0.042 & 0.014 & 0.091 & 0.076 & 0.043 & 0.102 & 0.065 \\
\hline $\mathrm{Zn}^{2+}$ & 1.209 & 0.869 & 0.982 & 1.107 & 1.223 & 1.344 & 1.381 & 1.455 & 1.484 \\
\hline $\mathrm{Al}^{3+}$ & 0.470 & 0.396 & 0.533 & 0.661 & 0.359 & 0.493 & 0.637 & 0.504 & 0.515 \\
\hline $\mathrm{Fe}^{3+}$ & 2.927 & 3.275 & 3.108 & 3.007 & 3.001 & 2.565 & 2.570 & 2.690 & 2.425 \\
\hline $\mathrm{Ti}^{4+}$ & 0.016 & 0.057 & 0.028 & 0.008 & 0.001 & 0.053 & 0.017 & 0.042 & 0.058 \\
\hline $\mathrm{Si}^{4+}$ & 0.005 & 0.001 & 0.005 & 0.006 & 0.002 & 0.003 & 0.000 & 0.001 & 0.004 \\
\hline $\mathrm{As}^{5+}$ & 0.069 & 0.075 & 0.104 & 0.195 & 0.040 & 0.062 & 0.043 & 0.057 & 0.047 \\
\hline $\mathrm{P}^{5+}$ & 2.924 & 2.920 & 2.874 & 2.797 & 2.958 & 2.935 & 2.952 & 2.942 & 2.949 \\
\hline $\mathrm{S}^{6+}$ & 0.002 & 0.004 & 0.016 & 0.002 & 0.000 & 0.000 & 0.005 & 0.000 & 0.000 \\
\hline $\mathrm{Cl}^{-}$ & 0.001 & 0.000 & 0.000 & 0.000 & 0.000 & 0.002 & 0.001 & 0.001 & 0.002 \\
\hline $\mathrm{OH}$ & 4.006 & 4.299 & 4.249 & 4.407 & 3.939 & 3.463 & 3.657 & 4.086 & 3.388 \\
\hline $\mathrm{Zn}$ in $M(a)$ & 0.787 & 0.795 & 0.838 & 0.873 & 0.749 & 0.754 & 0.895 & 0.727 & 0.761 \\
\hline total $M(a)$ & 1.000 & 1.000 & 1.000 & 1.000 & 1.000 & 1.000 & 1.000 & 1.000 & 1.000 \\
\hline $\mathrm{Zn}$ in $M(b)$ & 0.422 & 0.074 & 0.144 & 0.233 & 0.474 & 0.591 & 0.486 & 0.728 & 0.723 \\
\hline total $M(b)$ & 3.836 & 3.802 & 3.813 & 3.910 & 3.835 & 3.703 & 3.711 & 3.965 & 3.721 \\
\hline
\end{tabular}

mean of all 19 spot analyses, 1-8 - representative spot analyses.

Empirical formulas were calculated on the basis of $(\mathrm{P}+\mathrm{As}+\mathrm{Si}+\mathrm{S})=3$;

$\mathrm{H}_{2} \mathrm{O}$ * content was calculated from the charge balance of general formula.
$\mathrm{Al}$ in the range of 0.30 to 0.66 apfu and

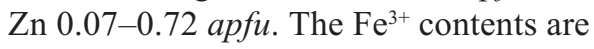
c. 2.43 to $3.28 \mathrm{apfu}$; the total occupancy of the $M(b)$ site, 3.61-3.96 apfu is near the theoretical content of 4 apfu.

The anion group in $\boldsymbol{U N K} \mathbf{3}$ contains dominant $\mathrm{P}$ (2.80-2.97 apfu), invariably As (0.03-0.19 apfu), and variably minor Si (max. $0.02 a p f u$ ) (Fig. 19). The presence of $\mathrm{M}^{1+}$ elements in $M(a)$-site and a significant content of $\mathrm{Zn}$ in $M(b)$-sites result in decrease of $(\mathrm{OH})$ groups from five (frondelite, rockbridgeite) to four in $\mathbf{U N K} \mathbf{3}$ (the calculated range of 3.40-4.40 (OH) $p f u$ ). The empirical formula for $\boldsymbol{U N K} \mathbf{3}$ $\left(\mathrm{Zn}_{0.79} \mathrm{Na}_{0.09} \mathrm{Mn}_{0.07} \mathrm{Ca}_{0.05}\right)_{\Sigma 1.00}\left(\mathrm{Fe}_{2.93} \mathrm{Zn}_{0.42} \mathrm{Al}_{0.47}\right.$ $\left.\mathrm{Ti}_{0.02}\right)_{\Sigma 3.84}\left[\left(\mathrm{PO}_{4}\right)_{2.92}\left(\mathrm{AsO}_{4}\right)_{0.07}\right]_{\Sigma 2.99}(\mathrm{OH})_{4.01}$ can be simplified to an ideal formula $\mathrm{Zn}(\mathrm{Fe}, \mathrm{Zn}, \mathrm{Al})_{4}\left(\mathrm{PO}_{4}\right)_{3}(\mathrm{OH})_{4}$.

\section{UNK4 CaAl phosphate fluoride - trigonal (?) $\mathrm{CaAl}_{3}\left(\mathrm{PO}_{4}\right)\left(\mathrm{PO}_{3} \mathrm{OH}\right)(\mathrm{OH}, \mathrm{F})_{6}(?)$}

UNK4 has been found in one phosphate accumulation sample collected at the $5^{\text {th }}$ level of the Huber shaft, Krásno (Sejkora et al. 2006c). The sample is composed dominantly of compact brownish fluorapatite free of obvious triplite relics and some massive white quartz. The phase UNK4 occurs as crystalline coatings 2.5 by $3 \mathrm{~cm}$ in size (Fig. 20) in irregular cavity of brownish fluorapatite. The associated minerals include abundant white to light pink younger fluorapatite and local green aggregates of minerals of the chalcosiderite-turquoise series. The surface of the UNK4 coatings is 
formed by $0.3 \mathrm{~mm}$ long aggregates of minute and very thin tabular crystals with maximum size of $0.1-0.2 \mathrm{~mm}$ (Fig. 21). The very brittle and soft $\boldsymbol{U N K} 4$ aggregates are white, yellowish or light pink. The aggregates have pearly lustre, individual transparent to translucent crystals have a vitreous lustre.

The sample studied by X-ray powder diffraction contained in addition to dominating phase $\boldsymbol{U N K} 4$ a signifi- cant admixture of fluorapatite (Table 9), which prevented reliable indexing of the diffractions. The X-ray data for $\boldsymbol{U N K} 4$ were indexed based on similarity with crandallite in the space group $P 3$. The refined unit-cell parameters are $a=6.984(1), c=16.796(3) \AA$ and $V=$ 709.5(3). However, it must be noted that in the angular range correponding to $d$-spacing between 20 to $6 \AA$, the major differences between the pattern for $\boldsymbol{U N K} 4$ and

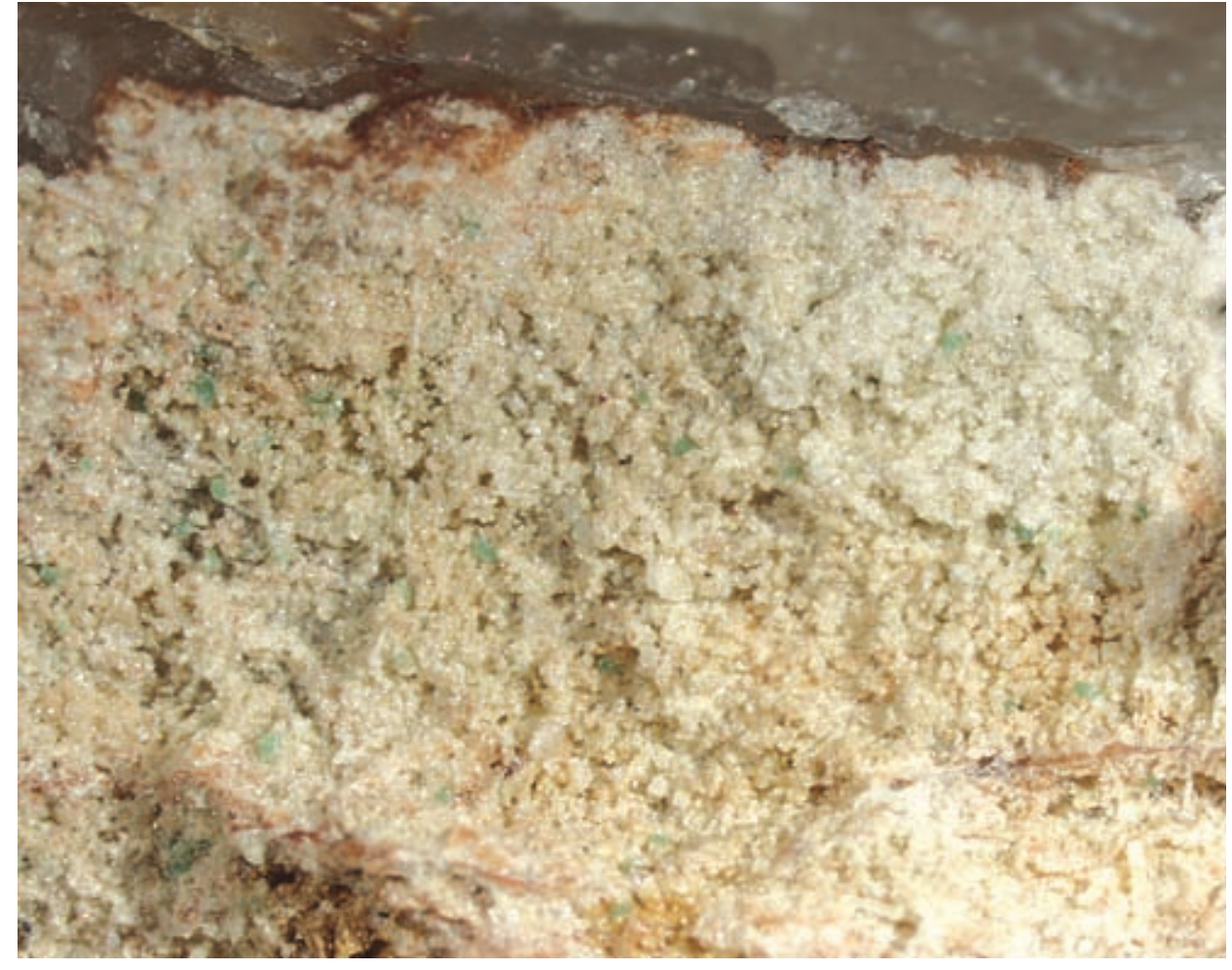

Fig. 20 Whitish aggregates of UNK4 from phosphate accumulation from the $5^{\text {th }}$ level of the Huber shaft, Krásno. Width of the area shown $8 \mathrm{~mm}$. Nikon SMZ1500, photograph by J. Sejkora.

Table 9 X-ray powder diffraction pattern of $\boldsymbol{U N K} \boldsymbol{4}$ from Krásno.

\begin{tabular}{|c|c|c|c|c|c|c|c|c|c|c|c|c|c|c|c|c|c|}
\hline$I_{r e l}$ & $d$ & & $h$ & $k$ & $l$ & $I_{r e l}$ & $d$ & & $h$ & $k$ & $l$ & $I_{r e l}$ & $d$ & & $h$ & $k$ & $l$ \\
\hline 100 & 16.812 & $*$ & 0 & 0 & 1 & 21 & 2.965 & $*$ & 1 & 1 & 3 & 9 & 1.9341 & $\mathrm{~F}$ & & & \\
\hline 21 & 8.399 & $*$ & 0 & 0 & 2 & 17 & 2.939 & $*$ & 0 & 1 & 5 & 9 & 1.8971 & $*$ & 0 & 3 & 3 \\
\hline 3 & 8.114 & $\mathrm{~F}$ & & & & 5 & 2.847 & $*$ & 0 & 2 & 2 & 4 & 1.8827 & $\mathrm{~F}$ & & & \\
\hline 10 & 6.056 & $*$ & 1 & 0 & 0 & 37 & 2.799 & $* \mathrm{~F}$ & 0 & 0 & 6 & 21 & 1.8670 & $*$ & 0 & 0 & 9 \\
\hline 18 & 5.697 & $*$ & 0 & 1 & 1 & 10 & 2.772 & $\mathrm{~F}$ & & & & 9 & 1.8366 & $\mathrm{~F}$ & & & \\
\hline 15 & 5.596 & $*$ & 0 & 0 & 3 & 29 & 2.702 & $\mathrm{~F}$ & & & & 6 & 1.8181 & $*$ & 0 & 3 & 4 \\
\hline 3 & 4.911 & $*$ & 0 & 1 & 2 & 4 & 2.660 & $*$ & 0 & 2 & 3 & 7 & 1.8120 & & & & \\
\hline 6 & 4.842 & & & & & 8 & 2.624 & $\mathrm{~F}$ & & & & 5 & 1.7967 & $*$ & 1 & 1 & 8 \\
\hline 7 & 4.202 & $*$ & 0 & 0 & 4 & 12 & 2.610 & & & & & 4 & 1.7935 & $\mathrm{~F}$ & & & \\
\hline 2 & 4.108 & $*$ & 0 & 1 & 3 & 10 & 2.543 & $*$ & 0 & 1 & 6 & 10 & 1.7692 & ${ }^{*} \mathrm{~F}$ & 2 & 1 & 6 \\
\hline 8 & 4.053 & $\mathrm{~F}$ & & & & 3 & 2.514 & $\mathrm{~F}$ & & & & 11 & 1.7462 & $* \mathrm{~F}$ & 2 & 2 & 0 \\
\hline 6 & 3.871 & $\mathrm{~F}$ & & & & 14 & 2.4033 & $*$ & 0 & 0 & 7 & 7 & 1.7229 & ${ }^{*} \mathrm{~F}$ & 2 & 0 & 8 \\
\hline 12 & 3.494 & $*$ & 1 & 1 & 0 & 8 & 2.2893 & $* \mathrm{~F}$ & 2 & 1 & 0 & 3 & 1.7097 & $*$ & 2 & 2 & 2 \\
\hline 13 & 3.443 & $* \mathrm{~F}$ & 1 & 0 & 4 & 21 & 2.2487 & $*$ & 0 & 2 & 5 & 7 & 1.6357 & $* \mathrm{~F}$ & 0 & 3 & 6 \\
\hline 15 & 3.341 & & & & & 24 & 2.2317 & $*$ & 0 & 1 & 7 & 7 & 1.5145 & & 1 & 1 & 10 \\
\hline 8 & 3.307 & & & & & 2 & 2.1800 & $*$ & 1 & 1 & 6 & 10 & 1.4683 & ${ }^{*} \mathrm{~F}$ & 0 & 2 & 10 \\
\hline 8 & 3.197 & & & & & 6 & 2.1358 & $\mathrm{~F}$ & & & & 6 & 1.4222 & & 0 & 4 & 4 \\
\hline 5 & 3.168 & $\mathrm{~F}$ & & & & 1 & 2.0606 & $\mathrm{~F}$ & & & & 5 & 1.3978 & & 1 & 1 & 11 \\
\hline 12 & 3.065 & $\mathrm{~F}$ & & & & 17 & 1.9845 & $*$ & 0 & 1 & 8 & 7 & 1.3644 & & 1 & 0 & 12 \\
\hline
\end{tabular}

* - diffraction maxima used for refinement of unit-cell parameters in proposed primitive trigonal cell

$\mathrm{F}$ - probable coincidence with fluorapatite 


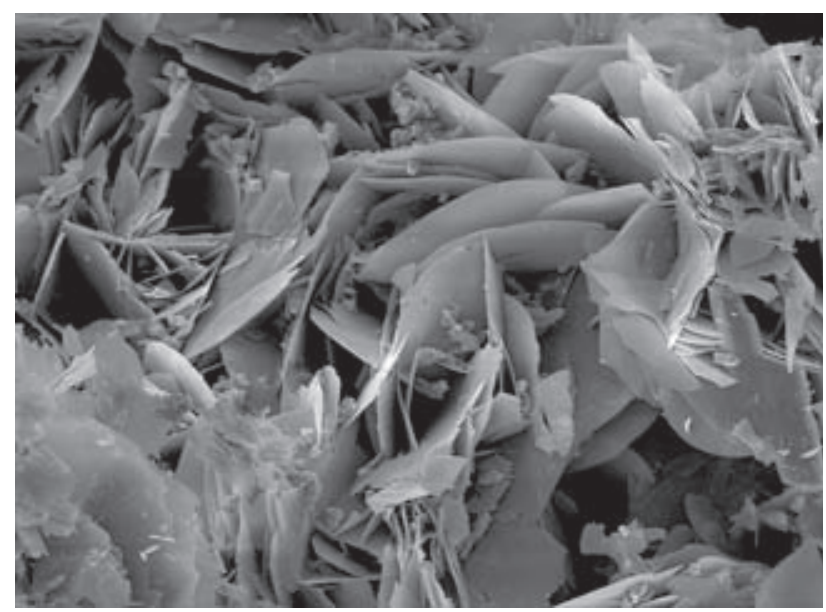

Fig. 21 Thin tabular crystals of $\boldsymbol{U N K}$, Krásno. Width of the area shown $140 \mu \mathrm{m}$. SEM photograph Jeol JSM-6380, J. Sejkora and J. Plášil

those of trigonal crandallite $(R-3 m$; Blount 1974) and probably triclinic crandallite (Cowgill et al. 1963) may be observed.

The quantitative chemical analyses of UNK4 show major contents of $\mathrm{Ca}, \mathrm{Al}, \mathrm{P}$ a F (Table 10). Therefore, it is possible that it is a fluorine-rich mineral, structurally related to crandallite $\mathrm{CaAl}_{3}\left(\mathrm{PO}_{4}\right)\left(\mathrm{PO}_{3} \mathrm{OH}\right)(\mathrm{OH}, \mathrm{F})_{6}$. The relatively low and variable analytic totals of UNK4 (after including calculated $\mathrm{H}_{2} \mathrm{O}$ content) are probably due to the surface properties of the analyzed sample, composed of very thin, tabular crystals. The chemical composition of the crandallite group minerals can be expressed by the general formula $\mathrm{AB}_{3}\left(\mathrm{TO}_{4}\right)\left(\mathrm{TO}_{3} \mathrm{OH}\right)$ $(\mathrm{OH}, \mathrm{F})_{6}$.

The $A$-site of $\boldsymbol{U N K} 4$ contains dominant Ca (1.06-1.30 apfu) and minor $\mathrm{K}(\max .0 .08), \mathrm{Sr}(\max .0 .06)$ and $\mathrm{Cu}$ (max. $0.01 \mathrm{apfu}$ ); the total for $A$-site is 1.21-1.46 apfu. In $B$-site Al (3.05-3.32 apfu) is the dominant element, $\mathrm{Fe}^{3+}$ content is in the range of 0.01-0.02 apfu; the total for $B$-site is 3.07-3.32 apfu. The tetrahedral $T$-site is dominated by P (1.83-1.99 apfu), with a local content of Si (max. 0.17 apfu). The relative deficiency in the $T$-site (as compared to cations in $A$ - and $B$-sites) is probably compensated by increased number of $(\mathrm{OH}, \mathrm{F})$ groups of $6.42-$ $7.72 \mathrm{pfu}$, compared to the theoretical number of 6.00 . There is an increased content of F (2.41-2.63 apfu) in the $(\mathrm{OH}, \mathrm{F})$-sites. Accepting the crandallite-type chemistry and the relation $(\mathrm{P}+\mathrm{As}+\mathrm{Si}+\mathrm{S})=2.00$, the empirical formula for $\boldsymbol{U N K} 4$ is $\left(\mathrm{Ca}_{1.16} \mathrm{~K}_{0.06} \mathrm{Ba}_{0.01} \mathrm{Sr}_{0.05}\right)_{\Sigma 1.28}\left(\mathrm{Al}_{3.24} \mathrm{Fe}_{0.02}\right)_{\Sigma 3.26}$ $\left[\left(\mathrm{PO}_{3} \mathrm{OH}\right)_{1.00}\left(\mathrm{PO}_{4}\right)_{0.91}\left(\mathrm{SiO}_{4}\right)_{0.08}\right]_{\Sigma 1.99}\left[(\mathrm{OH})_{4.75} \mathrm{~F}_{2.51}\right]_{\Sigma 7.26}$.

Re-calculation of the analyses on an alternative basis is possible, e.g., assuming $(\mathrm{P}+\mathrm{As}+\mathrm{Si}+\mathrm{S})=3$. This results in the empirical formula $(\mathrm{Ca} \ldots)_{1.97}(\mathrm{Al} \ldots)_{4.88}\left[\left(\mathrm{PO}_{4}\right) \ldots\right]_{3}$ $\left[(\mathrm{OH})_{5.61} \mathrm{~F}_{3.77}\right]_{\Sigma 9.38}$.
Ta b le 10 Chemical composition of $\boldsymbol{U N K} \mathbf{4}$ from Krásno (in wt. \%)

\begin{tabular}{|c|c|c|c|c|c|}
\hline & mean & 1 & 2 & 3 & 4 \\
\hline $\mathrm{Na}_{2} \mathrm{O}$ & 0.02 & 0.03 & 0.00 & 0.00 & 0.05 \\
\hline $\mathrm{K}_{2} \mathrm{O}$ & 0.57 & 0.51 & 0.57 & 0.56 & 0.66 \\
\hline $\mathrm{CaO}$ & 12.41 & 12.13 & 11.70 & 13.13 & 12.67 \\
\hline $\mathrm{MgO}$ & 0.04 & 0.00 & 0.05 & 0.06 & 0.04 \\
\hline $\mathrm{PbO}$ & 0.09 & 0.00 & 0.12 & 0.11 & 0.14 \\
\hline $\mathrm{CuO}$ & 0.11 & 0.21 & 0.21 & 0.00 & 0.00 \\
\hline $\mathrm{ZnO}$ & 0.02 & 0.04 & 0.00 & 0.03 & 0.00 \\
\hline $\mathrm{MnO}$ & 0.04 & 0.00 & 0.02 & 0.09 & 0.03 \\
\hline $\mathrm{BaO}$ & 0.34 & 0.57 & 0.00 & 0.64 & 0.16 \\
\hline $\mathrm{SrO}$ & 1.08 & 1.25 & 0.95 & 1.04 & 1.08 \\
\hline $\mathrm{Fe}_{2} \mathrm{O}_{3}$ & 0.30 & 0.35 & 0.39 & 0.23 & 0.23 \\
\hline $\mathrm{Al}_{2}^{2} \mathrm{O}_{3}^{3}$ & 31.35 & 31.77 & 31.22 & 33.13 & 29.30 \\
\hline $\mathrm{TiO}_{2}{ }^{3}$ & 0.02 & 0.00 & 0.03 & 0.00 & 0.06 \\
\hline $\mathrm{SiO}_{2}$ & 0.93 & 2.11 & 0.00 & 0.77 & 0.83 \\
\hline $\mathrm{P}_{2} \mathrm{O}_{5}$ & 25.81 & 26.47 & 26.11 & 26.95 & 23.70 \\
\hline $\mathrm{As}_{2} \mathrm{O}_{5}$ & 0.06 & 0.00 & 0.16 & 0.00 & 0.08 \\
\hline $\mathrm{SO}_{3}$ & 0.05 & 0.00 & 0.09 & 0.10 & 0.00 \\
\hline $\mathrm{F}$ & 9.07 & 9.38 & 9.09 & 9.82 & 7.98 \\
\hline$-\mathrm{O}=\mathrm{F}$ & -3.82 & -3.95 & -3.83 & -4.14 & -3.36 \\
\hline $\mathrm{H}_{2} \mathrm{O}^{*}$ & 11.00 & 10.10 & 11.18 & 11.14 & 11.62 \\
\hline total & 89.48 & 90.98 & 88.04 & 93.68 & 85.26 \\
\hline $\mathrm{Na}$ & 0.003 & 0.005 & 0.000 & 0.000 & 0.009 \\
\hline $\mathrm{K}$ & 0.064 & 0.053 & 0.065 & 0.061 & 0.080 \\
\hline $\mathrm{Ca}$ & 1.164 & 1.060 & 1.126 & 1.189 & 1.297 \\
\hline $\mathrm{Ba}$ & 0.012 & 0.018 & 0.000 & 0.021 & 0.006 \\
\hline $\mathrm{Sr}$ & 0.055 & 0.059 & 0.049 & 0.051 & 0.060 \\
\hline $\mathrm{Mg}$ & 0.005 & 0.000 & 0.006 & 0.007 & 0.006 \\
\hline $\mathrm{Pb}$ & 0.002 & 0.000 & 0.003 & 0.003 & 0.004 \\
\hline $\mathrm{Cu}$ & 0.007 & 0.013 & 0.014 & 0.000 & 0.000 \\
\hline $\mathrm{Mn}$ & 0.003 & 0.000 & 0.002 & 0.007 & 0.002 \\
\hline $\mathrm{Zn}$ & 0.001 & 0.002 & 0.000 & 0.002 & 0.000 \\
\hline total $A$-site & 1.316 & 1.211 & 1.266 & 1.340 & 1.464 \\
\hline $\mathrm{Al}^{3+}$ & 3.235 & 3.053 & 3.306 & 3.300 & 3.299 \\
\hline $\mathrm{Fe}^{3+}$ & 0.020 & 0.022 & 0.026 & 0.015 & 0.016 \\
\hline $\mathrm{Ti}^{4+}$ & 0.001 & 0.000 & 0.002 & 0.000 & 0.004 \\
\hline total $B$-site & 3.256 & 3.075 & 3.334 & 3.315 & 3.320 \\
\hline $\mathrm{Si}$ & 0.081 & 0.172 & 0.000 & 0.065 & 0.079 \\
\hline As & 0.003 & 0.000 & 0.008 & 0.000 & 0.004 \\
\hline $\mathrm{Pb}$ & 1.913 & 1.828 & 1.986 & 1.929 & 1.917 \\
\hline $\mathrm{S}$ & 0.003 & 0.000 & 0.006 & 0.006 & 0.000 \\
\hline total $T$-site & 2.000 & 2.000 & 2.000 & 2.000 & 2.000 \\
\hline $\mathrm{F}$ & 2.511 & 2.420 & 2.583 & 2.625 & 2.412 \\
\hline $\mathrm{H}$ & 5.745 & 4.996 & 5.898 & 5.882 & 6.312 \\
\hline $\mathrm{OH}$ in $\left(\mathrm{PO}_{3} \mathrm{OH}\right)$ & 1.000 & 1.000 & 1.000 & 1.000 & 1.000 \\
\hline$(\mathrm{OH})$ & 4.745 & 3.996 & 4.898 & 4.882 & 5.312 \\
\hline$(\mathrm{OH})+\mathrm{F}$ & 7.256 & 6.415 & 7.477 & 7.506 & 7.724 \\
\hline
\end{tabular}

Empirical formulas were calculated on the basis of $(\mathrm{P}+\mathrm{As}+\mathrm{Si}+\mathrm{S})=2$; all $\mathrm{Fe}_{\text {tot }}$ as $\mathrm{Fe}^{3+} ; * \mathrm{H}_{2} \mathrm{O}$ content calculated from charge balance.

\section{UNK5 $\mathrm{Pb}-\mathrm{U}$ oxide/hydroxide $-\mathrm{Pb}\left(\mathrm{UO}_{2}\right)_{3} \mathrm{O}_{3}(\mathrm{OH})_{2}$. $3 \mathrm{H}_{2} \mathrm{O}$ (?)}

UNK5 has been found in several historical specimens (NMCR, collected 1949) from Oktyabrskaya vein of the Horní Slavkov uranium ore district (Plášil et al. 2006). The phase occurs in uraninite veinlets to $1 \mathrm{~cm}$ wide, affected by a strong supergene alteration. Yellow uranophane and phosphuranylite, yellow and yellow-orange 
rutherfordine crusts, light yellow-green tabular crystals of autunite and rare nováčekite are the associated minerals. The aggregates of $\boldsymbol{U N K \boldsymbol { 5 }}$ are limited to $5 \mathrm{~mm}$ long, black relics of hydrated uraninite in altered gangue. The phase usually forms minor veinlets to $0.2 \mathrm{~mm}$ wide (Fig. 22) or rare equant aggregates to $0.5 \mathrm{~mm}$, intergrown with black uraninite, yellow uranophane and light yellowgreen nováčekite (Fig. 23). UNK5 has a conspicuous orange-red colour, it is transparent, with vitreous lustre and conchoidal fracture.

The X-ray powder diffraction data for $\boldsymbol{U N K 5}$ from Horní Slavkov (Table 11) correspond to data published for an unnamed $\mathrm{PbO}-\mathrm{UO}_{3}-\mathrm{H}_{2} \mathrm{O}$ phase from the Rovnost mine, Jáchymov (Ondruš et al. 1997). The sample from Horní Slavkov contains probably admixture of nováčekite. X-ray powder diffraction data for $\boldsymbol{U N K 5}$ are differ-

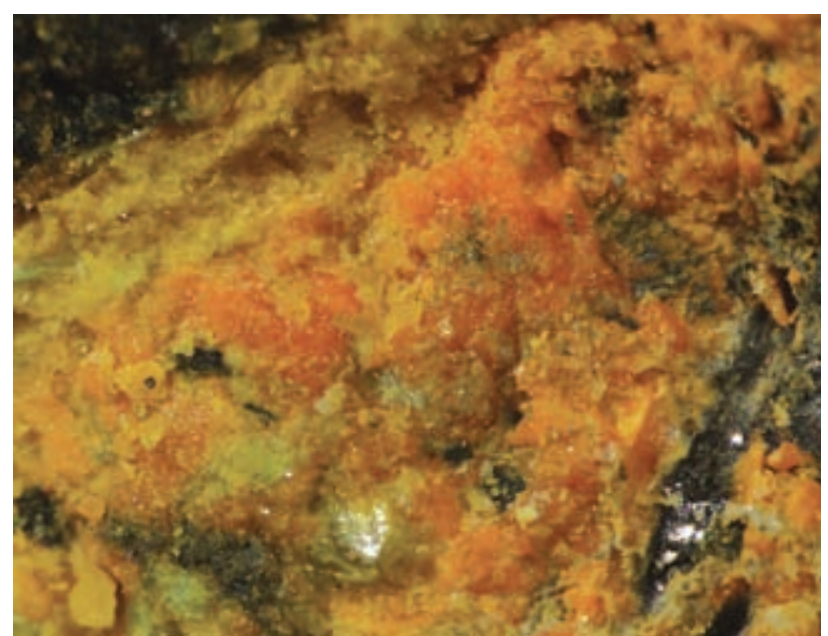

Fig. 22 Orange-red veinlets of $\boldsymbol{U N K} \mathbf{5}$ in black hydrated uraninite with yellow uranophane and greenish nováčekite. Oktyabrskaya vein, Horní Slavkov uranium ore district. Width of the area shown $2 \mathrm{~mm}$. Nikon SMZ1500 photograph by J. Sejkora.

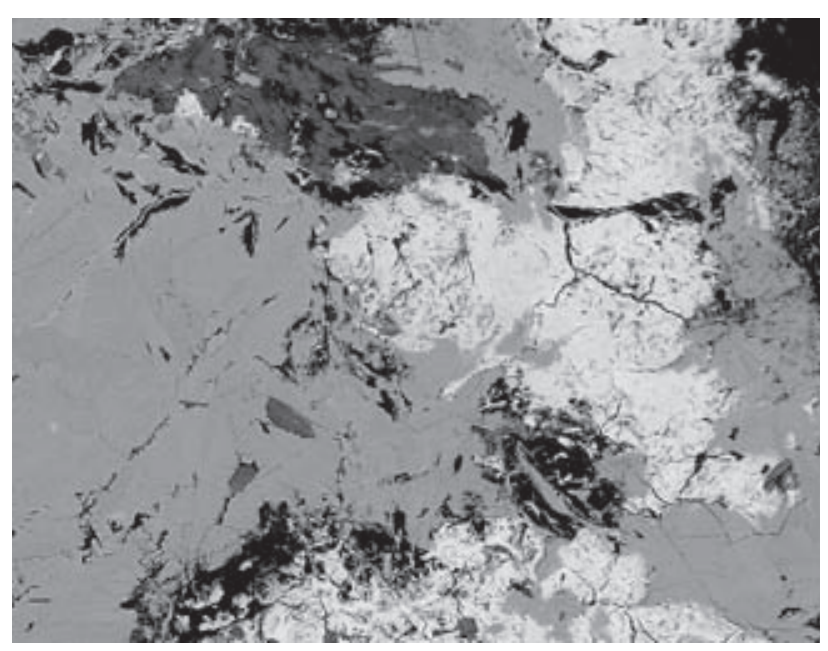

Fig. 23 UNK5 aggregates (light) replacing hydrated uraninite (grey) with nováčekite (dark grey) occurring in cavities and along fractures. Horní Slavkov uranium ore district. Width of the area shown $500 \mu \mathrm{m}$. Cameca SX100, BSE photograph by J. Sejkora and R. Škoda. ent from those presented for minerals compositionally related to $\boldsymbol{U N K} 5$ specifically masuyite (Finch - Ewing 1992; Deliens - Piret 1996; Burns - Hanchar 1999) and richetite (Burns 1998).

Quantitative chemical analyses of UNK5 (Table 12) show that the phase is a hydrated oxide/hydroxide of $\mathrm{Pb}$ and $U$ with contents of these elements (Fig. 24) close to those of one type of masuyite, reported by Burns - Hanchar (1999), Finch - Ewing (1992) (masuyite I) and Deliens - Piret (1996) ("grooved masuyite"). For this reason, analyses of $\boldsymbol{U N K} \mathbf{5}$ were re-calculated on the basis of $U=3$. In contrast to the published masuyite analyses, UNK5 contains minor quantities of other elements (contents expressed as apfu fractions): $0.05 \mathrm{Ca}, 0.04 \mathrm{~K}, 0.04$ $\mathrm{Al}, 0.03 \mathrm{Na}$ etc. Based on analogy with masuyite, the empirical formula is $\left(\mathrm{Pb}_{0.81} \mathrm{Ca}_{0.04} \mathrm{~K}_{0.03} \mathrm{Na}_{0.02} \mathrm{Mg}_{0.01} \mathrm{Al}_{0.01}\right)_{\Sigma 0.92}$ $\left(\mathrm{UO}_{2}\right)_{3.00} \mathrm{O}_{3}(\mathrm{OH})_{1.67} \cdot 3 \mathrm{H}_{2} \mathrm{O}$. Figure 24 indicates that the composition of UNK5 is close to the published data for richetite. Recalculation of analyses of the phase from Horní Slavkov on the basis of general formula for richetite proposed by Burns (1998) results in empirical formula $\mathrm{M}_{1.61} \mathrm{~Pb}_{9.69}\left[\left(\mathrm{UO}_{2}\right)_{18} \mathrm{O}_{18}(\mathrm{OH})_{10.04}\right]$. 41 $\mathrm{H}_{2} \mathrm{O}$. This formula requires 6.91 wt. $\% \mathrm{H}_{2} \mathrm{O}$ and the analysis total would be $101.63 \mathrm{wt}$ \% . A problematic question in mineralogy with chemical compositions close to richetite is the occupancy of $M$-site by elements such as $\mathrm{Mg}, \mathrm{Fe}$, etc. Burns (1998) derived their content from the crystal structure study as corresponding to 0.47 a 0.83 apfu respectively, but microprobe study of identical materi-
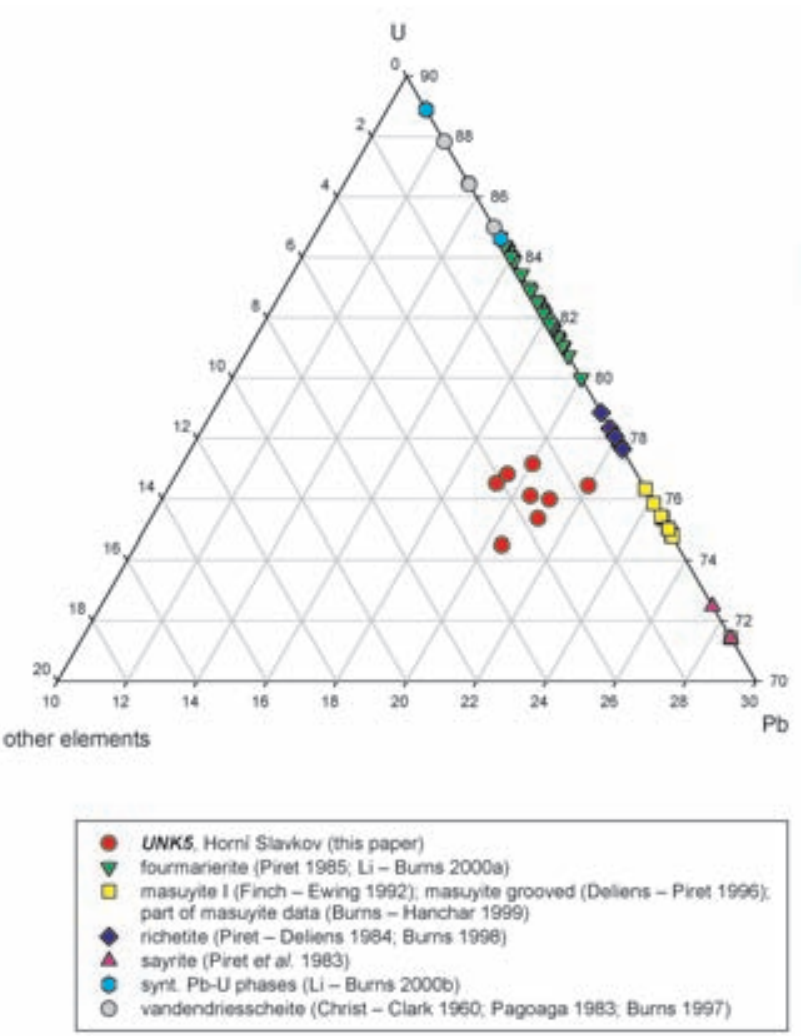

Fig. 24 Part of ternary plot of $\mathrm{Pb}-\mathrm{U}-\mathrm{X}$ in $\boldsymbol{U N K} 5$ from Krásno, compared with published data for other $\mathrm{Pb}-\mathrm{U}-\mathrm{O}-\mathrm{H}_{2} \mathrm{O}$ minerals. 
Table 11 X-ray powder diffraction pattern of $\boldsymbol{U N K \boldsymbol { N }}$

\begin{tabular}{|c|c|c|c|c|c|c|c|c|c|c|c|}
\hline$I_{r e l}$ & $d$ & $I_{r e l}{ }^{*}$ & $d^{*}$ & $I_{r e l}$ & $d$ & $I_{r e l} *$ & $d^{*}$ & $I_{r e l}$ & $d$ & $I_{r e l}^{*}$ & $d^{*}$ \\
\hline & & 2 & 16.993 & 32 & 3.689 & 40 & 3.691 & 6 & $2.2504 \mathrm{~N}$ & 6 & 2.2557 \\
\hline 4 & 16.293 & 6 & 16.155 & 9 & 3.607 & & & 6 & 2.2231 & 4 & 2.2254 \\
\hline 28 & 10.372 & 5 & 10.280 & 63 & $3.542 \mathrm{~N}$ & 44 & 3.542 & 6 & 2.2011 & 4 & 2.1995 \\
\hline 48 & $9.981 \mathrm{~N}$ & & & 29 & 3.477 & 14 & 3.479 & 2 & 2.1691 & 5 & 2.1720 \\
\hline 46 & 8.706 & 9 & 8.825 & 11 & 3.428 & & & 7 & 2.1090 & 8 & 2.1068 \\
\hline 51 & 7.994 & 40 & 7.907 & 22 & $3.358 \mathrm{~N}$ & 21 & 3.355 & 4 & 2.0866 & 2 & 2.0899 \\
\hline 82 & 7.641 & 100 & 7.630 & 14 & 3.331 & & & 4 & 2.0590 & 7 & 2.0668 \\
\hline 68 & 7.230 & & & 7 & 3.272 & 11 & 3.277 & 10 & 2.0273 & 10 & 2.0318 \\
\hline 71 & 7.069 & 78 & 7.071 & 100 & 3.212 & 83 & 3.216 & 11 & $1.9922 \mathrm{~N}$ & 10 & 2.0205 \\
\hline 5 & $6.733 \mathrm{~N}$ & & & 40 & $3.167 \mathrm{~N}$ & 21 & 3.170 & 19 & 1.9766 & 14 & 1.9790 \\
\hline 10 & 6.367 & 8 & 6.354 & 14 & 3.094 & 4 & 3.099 & 13 & 1.9737 & 9 & 1.9626 \\
\hline 2 & 6.123 & & & 12 & 3.057 & & & 10 & 1.9475 & 4 & 1.9509 \\
\hline 21 & 5.930 & 12 & 5.934 & 18 & 3.034 & 9 & 3.039 & 1 & 1.9311 & 6 & 1.9315 \\
\hline 9 & 5.707 & 5 & 5.705 & 11 & 3.009 & 11 & 3.004 & 7 & 1.9159 & 18 & 1.9208 \\
\hline 28 & 5.637 & 35 & 5.641 & 7 & 2.962 & & & 14 & 1.8900 & 18 & 1.8934 \\
\hline 3 & 5.258 & & & 22 & $2.897 \mathrm{~N}$ & 23 & 2.901 & 14 & 1.8787 & 7 & 1.8799 \\
\hline 9 & 5.200 & & & 1 & 2.817 & 6 & 2.821 & 1 & 1.8554 & 13 & 1.8563 \\
\hline 10 & $5.035 \mathrm{~N}$ & 12 & 5.005 & 10 & 2.762 & 16 & 2.763 & 7 & $1.8206 \mathrm{~N}$ & 7 & 1.8193 \\
\hline 19 & 4.982 & 4 & 4.953 & 7 & 2.705 & 11 & 2.704 & 12 & 1.8097 & 8 & 1.8121 \\
\hline 4 & 4.765 & & & 4 & 2.641 & & & 3 & 1.8026 & 13 & 1.8039 \\
\hline 5 & 4.471 & 6 & 4.457 & 17 & 2.616 & 20 & 2.619 & 8 & 1.7961 & & \\
\hline 8 & 4.411 & & & 10 & 2.577 & 6 & 2.575 & 6 & $1.7754 \mathrm{~N}$ & & \\
\hline \multirow[t]{2}{*}{11} & 4.338 & 1 & 4.340 & & & 3 & 2.547 & 11 & 1.7450 & 3 & 1.7537 \\
\hline & & 7 & 4.258 & 9 & $2.529 \mathrm{~N}$ & & & 6 & 1.7277 & 11 & 1.7221 \\
\hline 2 & 4.168 & 2 & 4.174 & 7 & 2.505 & 3 & 2.509 & 17 & 1.7180 & & \\
\hline 2 & 4.081 & 7 & 4.069 & 6 & 2.4918 & 5 & 2.4897 & & & 4 & 1.6735 \\
\hline 32 & 3.989 & 13 & 3.967 & 6 & 2.4311 & 6 & 2.4301 & 3 & 1.6393 & 4 & 1.6424 \\
\hline 32 & 3.929 & 27 & 3.924 & 4 & 2.3937 & 2 & 2.3927 & 4 & 1.6089 & 4 & 1.6082 \\
\hline 26 & 3.899 & 38 & 3.895 & 11 & 2.3534 & 12 & 3.5510 & & & 4 & 1.5728 \\
\hline 7 & 3.802 & 10 & 3.813 & 5 & 2.2903 & 4 & 2.2893 & 3 & 1.5510 & 5 & 1.5520 \\
\hline
\end{tabular}

$\mathrm{I}_{\text {rel }} *$ and $\mathrm{d}^{*}$ - unnamed $\mathrm{PbO}-\mathrm{UO}_{3}-\mathrm{H}_{2} \mathrm{O}$ phase (Ondruš et al. 1997)

$\mathrm{N}$ - probable coincidence with nováčekite

Fig. 25 Radiating aggregates of UNK6 from Huber open pit, Krásno. Width of the area shown $1.5 \mathrm{~mm}$. Nikon SMZ1500 photograph by J. Sejkora.

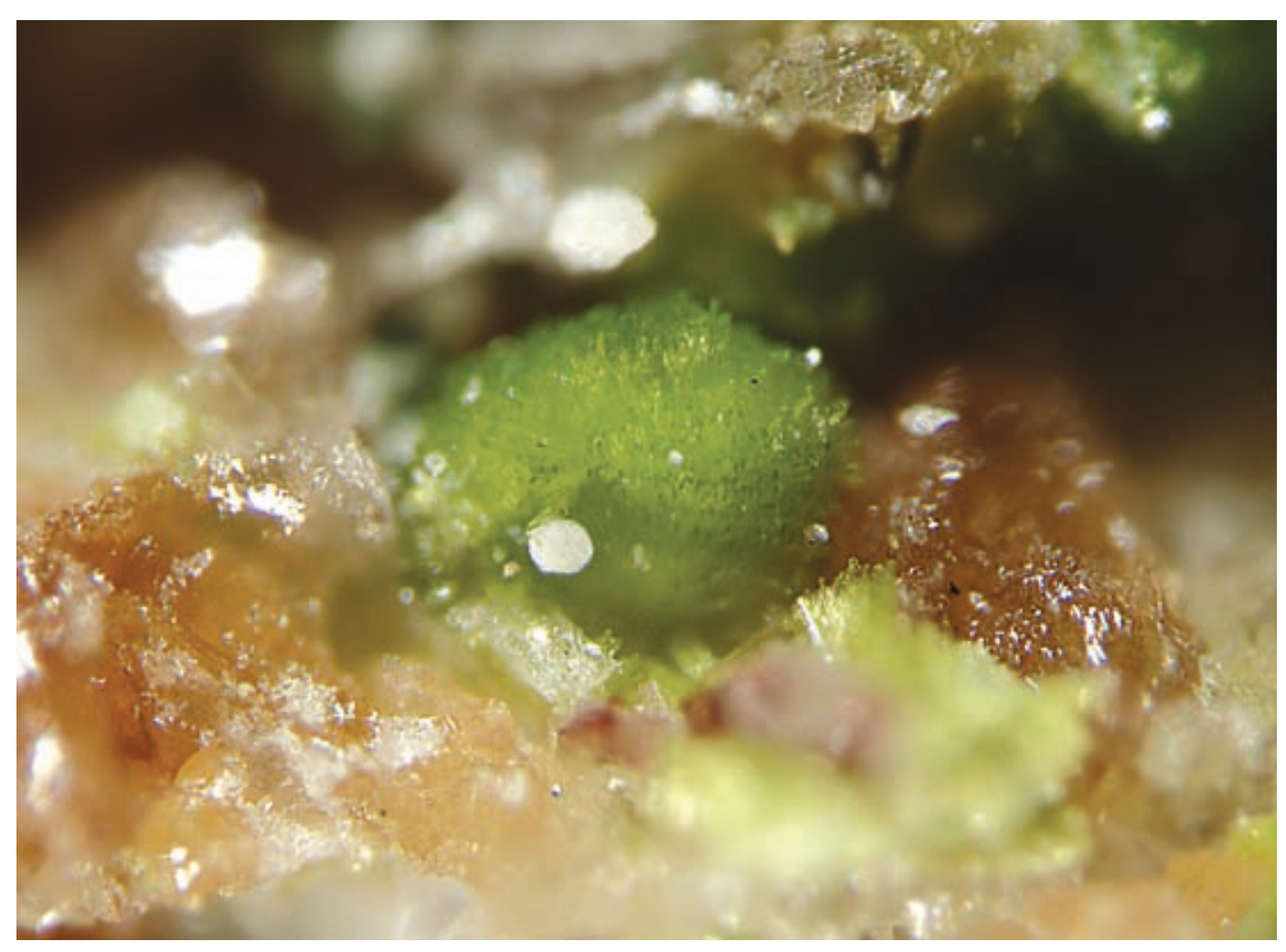


Table 12 Chemical composition of $\boldsymbol{U N K}$ 5 (in wt. \%)

\begin{tabular}{|c|c|c|c|c|c|c|c|c|}
\hline & mean & 1 & 2 & 3 & 4 & 5 & 6 & 7 \\
\hline $\mathrm{Na}_{2} \mathrm{O}$ & 0.05 & 0.06 & 0.10 & 0.04 & 0.04 & 0.07 & 0.00 & 0.01 \\
\hline $\mathrm{K}_{2} \mathrm{O}$ & 0.11 & 0.16 & 0.02 & 0.16 & 0.11 & 0.14 & 0.14 & 0.07 \\
\hline $\mathrm{CaO}$ & 0.19 & 0.16 & 0.18 & 0.11 & 0.20 & 0.23 & 0.27 & 0.18 \\
\hline $\mathrm{FeO}$ & 0.04 & 0.00 & 0.02 & 0.06 & 0.00 & 0.01 & 0.22 & 0.00 \\
\hline $\mathrm{BaO}$ & 0.02 & 0.00 & 0.01 & 0.03 & 0.07 & 0.00 & 0.03 & 0.00 \\
\hline $\mathrm{MgO}$ & 0.04 & 0.03 & 0.10 & 0.06 & 0.06 & 0.00 & 0.06 & 0.00 \\
\hline $\mathrm{PbO}$ & 16.25 & 16.01 & 16.89 & 15.41 & 16.78 & 15.14 & 16.60 & 16.95 \\
\hline $\mathrm{CuO}$ & 0.06 & 0.05 & 0.00 & 0.18 & 0.00 & 0.19 & 0.00 & 0.00 \\
\hline $\mathrm{ZnO}$ & 0.06 & 0.00 & 0.17 & 0.00 & 0.11 & 0.07 & 0.09 & 0.00 \\
\hline $\mathrm{Al}_{2} \mathrm{O}_{3}$ & 0.05 & 0.03 & 0.04 & 0.03 & 0.00 & 0.04 & 0.20 & 0.03 \\
\hline $\mathrm{Bi}_{2} \mathrm{O}_{3}$ & 0.12 & 0.06 & 0.09 & 0.26 & 0.00 & 0.24 & 0.17 & 0.02 \\
\hline $\mathrm{SiO}_{2}$ & 0.19 & 0.09 & 0.09 & 0.00 & 0.11 & 0.15 & 0.44 & 0.41 \\
\hline $\mathrm{As}_{2} \mathrm{O}$ & 0.02 & 0.11 & 0.00 & 0.04 & 0.00 & 0.00 & 0.03 & 0.00 \\
\hline $\mathrm{P}_{2} \mathrm{O}_{5}$ & 0.02 & 0.00 & 0.00 & 0.02 & 0.05 & 0.04 & 0.00 & 0.03 \\
\hline $\mathrm{V}_{2} \mathrm{O}_{5}$ & 0.03 & 0.08 & 0.00 & 0.00 & 0.03 & 0.05 & 0.00 & 0.03 \\
\hline $\mathrm{SO}_{3}$ & 0.08 & 0.06 & 0.00 & 0.21 & 0.07 & 0.03 & 0.07 & 0.16 \\
\hline $\mathrm{UO}_{3}$ & 77.35 & 79.04 & 77.33 & 77.85 & 77.42 & 76.89 & 77.38 & 75.53 \\
\hline $\mathrm{Cl}$ & 0.02 & 0.06 & 0.05 & 0.01 & 0.00 & 0.04 & 0.02 & 0.00 \\
\hline $\mathrm{H}_{2} \mathrm{O}^{*}$ & 6.23 & 6.30 & 6.39 & 6.30 & 6.27 & 6.17 & 6.28 & 5.91 \\
\hline total & 100.95 & 102.28 & 101.47 & 100.78 & 101.31 & 99.51 & 101.98 & 99.31 \\
\hline $\mathrm{Na}^{+}$ & 0.016 & 0.019 & 0.035 & 0.013 & 0.016 & 0.026 & 0.000 & 0.003 \\
\hline $\mathrm{K}^{+}$ & 0.027 & 0.037 & 0.004 & 0.038 & 0.026 & 0.032 & 0.032 & 0.016 \\
\hline $\mathrm{Ca}^{2+}$ & 0.037 & 0.031 & 0.035 & 0.022 & 0.039 & 0.046 & 0.054 & 0.036 \\
\hline $\mathrm{Fe}^{2+}$ & 0.007 & 0.000 & 0.003 & 0.010 & 0.000 & 0.001 & 0.034 & 0.000 \\
\hline $\mathrm{Ba}^{2+}$ & 0.002 & 0.000 & 0.001 & 0.002 & 0.005 & 0.000 & 0.002 & 0.000 \\
\hline $\mathrm{Mg}^{2+}$ & 0.012 & 0.007 & 0.026 & 0.016 & 0.015 & 0.000 & 0.017 & 0.000 \\
\hline $\mathrm{Pb}^{2+}$ & 0.808 & 0.779 & 0.840 & 0.761 & 0.833 & 0.757 & 0.825 & 0.863 \\
\hline $\mathrm{Cu}^{2+}$ & 0.008 & 0.006 & 0.000 & 0.025 & 0.000 & 0.027 & 0.000 & 0.000 \\
\hline $\mathrm{Zn}^{2+}$ & 0.008 & 0.000 & 0.023 & 0.000 & 0.014 & 0.010 & 0.012 & 0.000 \\
\hline $\mathrm{Al}^{3+}$ & 0.012 & 0.007 & 0.009 & 0.006 & 0.000 & 0.010 & 0.043 & 0.006 \\
\hline $\mathrm{Bi}^{3+}$ & 0.006 & 0.003 & 0.004 & 0.012 & 0.000 & 0.012 & 0.008 & 0.001 \\
\hline $\mathrm{Si}^{4+}$ & 0.034 & 0.017 & 0.016 & 0.000 & 0.021 & 0.029 & 0.080 & 0.078 \\
\hline $\mathrm{As}^{5+}$ & 0.002 & 0.010 & 0.000 & 0.003 & 0.000 & 0.000 & 0.003 & 0.000 \\
\hline $\mathrm{P}^{5+}$ & 0.003 & 0.000 & 0.000 & 0.004 & 0.008 & 0.006 & 0.000 & 0.005 \\
\hline $\mathrm{V}^{5+}$ & 0.003 & 0.009 & 0.000 & 0.000 & 0.003 & 0.006 & 0.000 & 0.004 \\
\hline $\mathrm{S}^{6+}$ & 0.012 & 0.008 & 0.000 & 0.029 & 0.009 & 0.004 & 0.009 & 0.022 \\
\hline $\mathrm{U}^{6+}$ & 3.000 & 3.000 & 3.000 & 3.000 & 3.000 & 3.000 & 3.000 & 3.000 \\
\hline $\mathrm{Cl}^{-}$ & 0.008 & 0.017 & 0.015 & 0.003 & 0.000 & 0.012 & 0.005 & 0.001 \\
\hline $\mathrm{H}^{+}$ & 7.673 & 7.593 & 7.872 & 7.709 & 7.715 & 7.644 & 7.731 & 7.454 \\
\hline $\mathrm{OH}$ & 1.673 & 1.587 & 1.871 & 1.701 & 1.720 & 1.647 & 1.724 & 1.457 \\
\hline $\mathrm{H}_{2} \mathrm{O}$ & 3.000 & 3.003 & 3.000 & 3.004 & 2.997 & 2.999 & 3.003 & 2.999 \\
\hline
\end{tabular}

Mean and spot analyses (1-7). Empirical formulas were calculated on the basis of $\left(\mathrm{UO}_{2}\right)^{2+}=3 ; \mathrm{H}_{2} \mathrm{O}$ * content was calculated from the charge balance and ideal content of 3 .

al shows that all elements, which potentially could enter the $M$-site, are below the detection limits of the instrument. UNK6 Cu-Fe phosphate (arthurite group) -
$\mathrm{CuFe}^{3+}{ }_{2}\left(\mathrm{PO}_{4}\right)_{2}(\mathrm{OH})_{2} \cdot 4 \mathrm{H}_{2} \mathrm{O}$

UNK6 occurs in several samples of phosphate accumulations from the Huber open pit (Sejkora et al. 2006c). Three morphological types of the phase are noted. They also differ in details of their chemical composition and by the associated minerals.

The first type, in the following designated as UNK6 "aggregates", occurs in place of the original triplite accumulations, more than $5 \mathrm{~cm}$ in size, which were later altered to brownish fluorapatite, accompanied by lighter compact isokite, and associated with white crystalline quartz. UNK6 is deposited in weathering cavities of $\mathrm{mm}$ to $2 \mathrm{~cm}$ size. It crystallized on coating of amorphous $\mathrm{Fe}$ or Mn-oxides or directly on relics of fresh, brown-red triplite. Small whitish UNK1 aggregates and rare very minute dark green crystals of chalcosiderite - turquoise minerals occur in association with $\boldsymbol{U N K \boldsymbol { K }}$. The mineral forms abundant radiating to semi-spheroidal aggregates to 1 $\mathrm{mm}$ (Fig. 25), composed of thin tabular crystals to $0.5 \mathrm{~mm}$ (Figs 26 and 27) and less common crystalline coatings up to several $\mathrm{mm}^{2}$ in size. The aggregates are bright yellow-green, sometimes with darker green rims and pearly lustre. Individual crystals show a lighter colour, they are translucent to transparent and show intense vitreous lustre.

A second type, designated as UNK6 "crystals", has been found in cavities to $3 \mathrm{~cm}$ in size in former triplite accumulations, almost completely altered to compact brown-pink fluorapatite. It is accompanied by abundant translucent leucophosphite crystals, crystals and aggregates of younger fluorapatite, less common crystalline aggregates of a chalcosiderite turquoise mineral and rare skeletal aggregates of UNK1. UNK6 forms relatively abundant, wellformed long tabular to flat acicular crystals (Fig. 28) up to $0.2 \mathrm{~mm}$ long. The crystals tend to form radiating or random groups. The individual UNK6 crystals are transparent to translucent, of predominating yellow-green colour and intense vitreous lustre. Some of the crystals show distinct colour zoning, with lighter (whitmoreite, earlshannonite, UNK8) and darker green (UNK7) parts. UNK6 is sometimes intergrown with colourless to very light yellowgreen whitmoreite and darker green UNK7, showing the same crystal morphology as UNK6.

The third type, designated as UNK6 "tables", occurs in a weathering cavity 1 by $1.5 \mathrm{~cm}$ in size, in altered phosphate aggregate (fluorapatite, isokite) in association with abundant water-clear crystals of

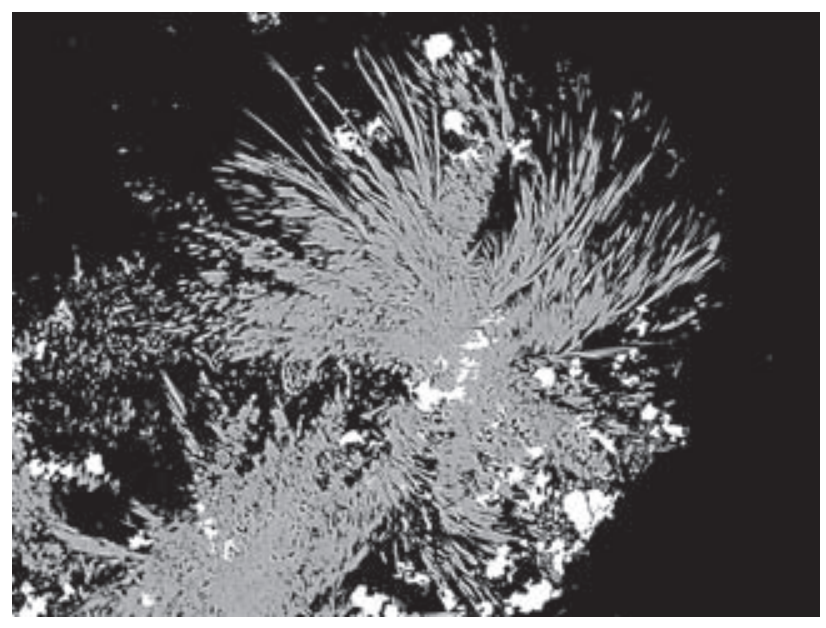

Fig. 26 Radiating agregates of thin tabular $\boldsymbol{U N K \boldsymbol { 6 }}$ crystals (grey) with minute chalcopyrite inclusions (light). Width of the area shown $300 \mu \mathrm{m}$. Cameca SX100 BSE photograph, by J. Sejkora and R. Škoda. 


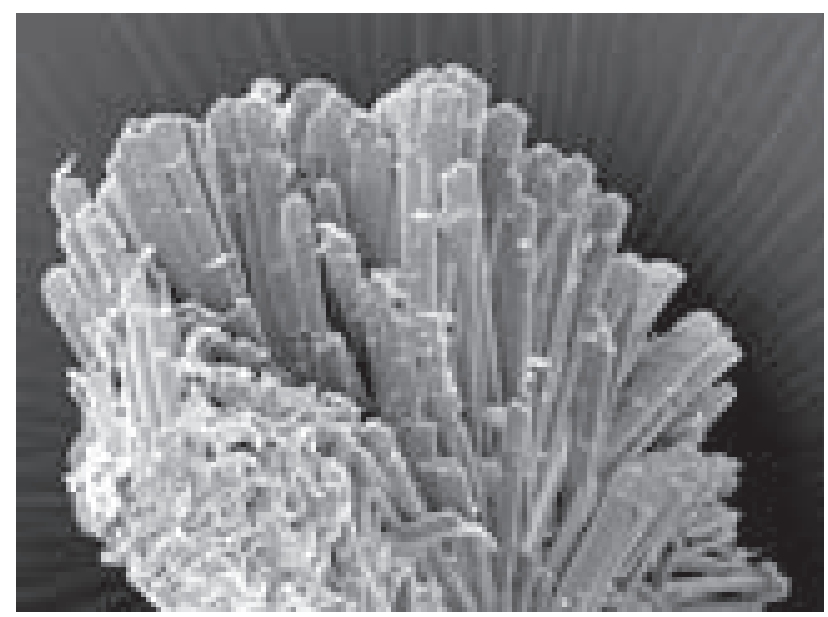

Fig. 27 Radiating agregates of $\boldsymbol{U N K \boldsymbol { 6 }}$ crystals, Krásno. Width of the area shown $200 \mu \mathrm{m}$. SEM photograph Jeol JSM-6380, J. Sejkora and J. Plášil

younger fluorapatite (sometimes with rutile inclusions), yellow crystals of pharmacosiderite and rare translucent leucophosphite and kolbeckite. In this association, UNK6 forms six-sided tabular aggregates (Fig. 29) up to $0.3 \mathrm{~mm}$ long, composed of tabular crystals, which show fibre-like cross-sections (Fig. 30). This type of $\boldsymbol{U N K \boldsymbol { 6 }}$ is light green with a yellow tint, aggregates show a limited transparency and a weak mat lustre.

The X-ray data of all three types of UNK6 from Krásno show clear relations of this new phase to the arthu- rite group. A sample of the type UNK6 "aggregates" was selected for a detailed study, due to the quantity of material available and its chemical homogeneity. The diffraction pattern (Table 13) was indexed using theoretical data calculated from the model of crystal structure for UNK6 (P analogue of arthurite - Keller - Hess 1978). The refined unit-cell parameters of $\boldsymbol{U N K \boldsymbol { 6 }}$ (Table 14) are closer to phosphates of the arthurite group than to analogous arsenates. This relation probably reflects the role of anion tetrahedra size: the $\left(\mathrm{PO}_{4}\right)$ tetrahedron with bond

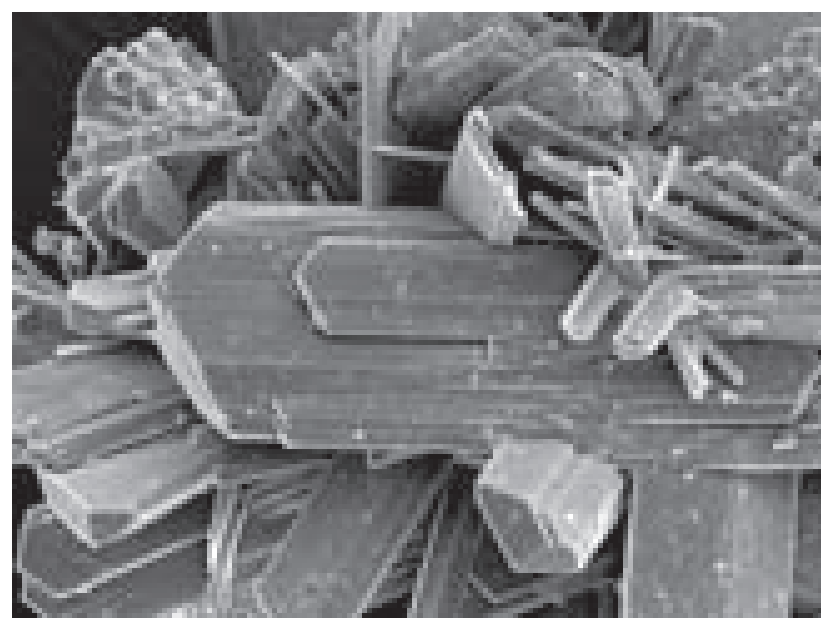

Fig. 28 Elongated tabular to flat acicular $\boldsymbol{U N K \boldsymbol { 6 }}$ crystals. Huber open pit, Krásno. Width of the area shown $150 \mu \mathrm{m}$. SEM photograph Jeol JSM-6380, J. Sejkora and J. Plášil

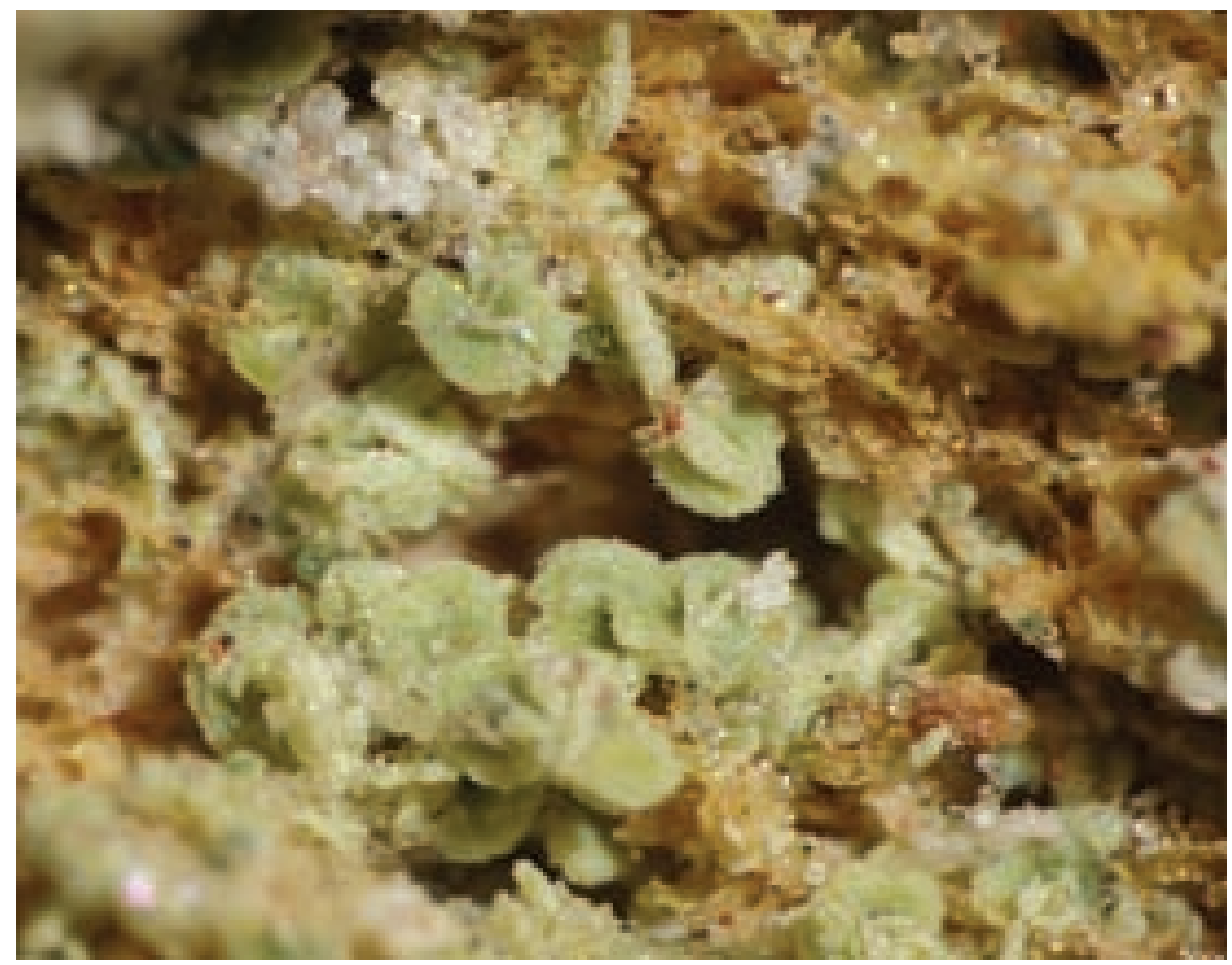

Fig. 29 Greenish tabular aggregates of UNK6 in cavity of phoshate accumulation, Huber open pit, Krásno. Width of the area shown $2 \mathrm{~mm}$. Nikon SMZ1500, photograph by J. Sejkora. 


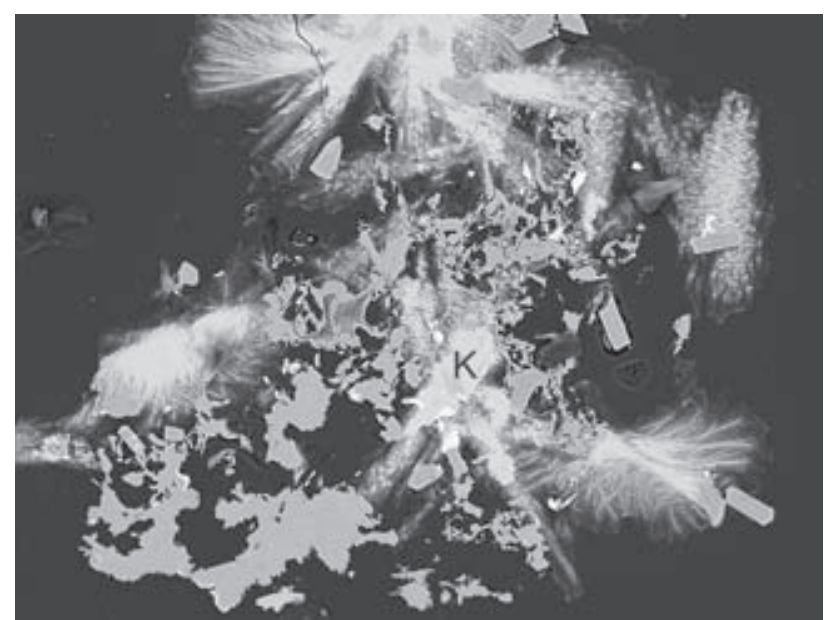

Fig. 30 Aggregates of very thin $\boldsymbol{U N K \boldsymbol { 6 }}$ tabular crystals (light grey), with kolbeckite crystal $(\mathrm{K})$ and fluorapatite aggregates (darker grey). Width of the area shown $400 \mu \mathrm{m}$. Cameca SX100 BSE photograph by J. Sejkora and R. Škoda. distance of 1.53-1.61 $\AA$ (Moore et al. 1974) is smaller than $\left(\mathrm{AsO}_{4}\right)$ tetrahedron with bond distance of $1.67-$ 1.72 A (Keller - Hess 1978; Kampf 2005).

Chemical composition of minerals of the arthurite group can be expressed by a general formula $A B_{2}\left(\mathrm{TO}_{4}\right)_{2}(\mathrm{OH}, \mathrm{O})_{2} \cdot 4 \mathrm{H}_{2} \mathrm{O}$ (Table 15). The structural position $A$ is occupied mainly by $\mathrm{M}^{2+}$ elements, such as $\mathrm{Cu}$, $\mathrm{Fe}^{2+}, \mathrm{Mn}^{2+}, \mathrm{Zn}, \mathrm{Co}, \mathrm{Mg}$ and $\mathrm{Ca}$ (Peacor et al. 1984, Jambor et al. 2002). According to Moore et al. (1974), also $\mathrm{Fe}^{3+}$ and vacancies may occur. The study of crystal structure indicates (Keller - Hess 1978, Hughes et al. 1996, Kampf 2005) that $\mathrm{Cu}, \mathrm{Zn}$ and Co enter exclusively the $A$-site. The $B$-site is occupied by dominant $\mathrm{Fe}^{3+}$ and some $\mathrm{Al}^{3+}$ (Peacor et al. 1984, Staněk 1988) and probably minor $\mathrm{Ti}^{4+}$ (Staněk 1988). It is also possible that monoclinic kleemanite $\mathrm{ZnAl}_{2}\left(\mathrm{PO}_{4}\right)_{2}(\mathrm{OH})_{2} .3 \mathrm{H}_{2} \mathrm{O}$ (Pilkington et al. 1979 ) is a member of the arthurite group with dominant Zn-Al-P.

Table 13 X-ray powder diffraction pattern of $\boldsymbol{U N K \boldsymbol { C }}$

\begin{tabular}{|c|c|c|c|c|c|c|c|c|c|c|c|c|c|c|}
\hline$I_{r e l}$ & $d$ & $h$ & $k$ & $l$ & $I_{r e l}$ & $d$ & $\boldsymbol{h}$ & $\boldsymbol{k}$ & $l$ & $I_{r e l}$ & $d$ & $\boldsymbol{h}$ & $\boldsymbol{k}$ & $l$ \\
\hline 100 & 9.852 & 1 & 0 & 0 & 9 & 2.3975 & 3 & 2 & 1 & 10 & 1.8149 & 0 & 5 & 1 \\
\hline 35 & 6.890 & 1 & 1 & 0 & 10 & 2.3940 & 2 & 3 & 1 & 11 & 1.7481 & 5 & 2 & -1 \\
\hline 73 & 4.920 & 2 & 0 & 0 & 13 & 2.3833 & 4 & 1 & 0 & 8 & 1.7146 & 2 & 5 & -1 \\
\hline 24 & 4.816 & 0 & 2 & 0 & 9 & 2.3740 & 0 & 2 & 2 & 9 & 1.7043 & 2 & 1 & -3 \\
\hline 7 & 4.757 & 0 & 1 & 1 & 12 & 2.3403 & 1 & 4 & 0 & 12 & 1.6986 & 2 & 5 & 1 \\
\hline 34 & 4.380 & 2 & 1 & 0 & 10 & 2.3279 & 1 & 2 & -2 & 9 & 1.6826 & 2 & 4 & 2 \\
\hline 9 & 4.326 & 1 & 2 & 0 & 9 & 2.2970 & 3 & 3 & 0 & 11 & 1.6801 & 4 & 2 & 2 \\
\hline 24 & 4.227 & 1 & 1 & 1 & 5 & 2.2833 & 2 & 1 & 2 & 13 & 1.6763 & 5 & 3 & 0 \\
\hline 20 & 3.4262 & 1 & 2 & -1 & 14 & 2.2044 & 0 & 4 & 1 & 5 & 1.6623 & 3 & 5 & 0 \\
\hline 20 & 3.2788 & 3 & 0 & 0 & 7 & 2.1889 & 4 & 2 & 0 & 5 & 1.6623 & 2 & 1 & 3 \\
\hline 16 & 3.0591 & 1 & 3 & 0 & 14 & 2.1533 & 4 & 1 & 1 & 11 & 1.6169 & 6 & 1 & 0 \\
\hline 16 & 2.9489 & 2 & 2 & -1 & 11 & 2.1371 & 3 & 3 & -1 & 12 & 1.6045 & 5 & 1 & -2 \\
\hline 23 & 2.8763 & 2 & 2 & 1 & 9 & 2.1096 & 2 & 2 & 2 & 7 & 1.5995 & 3 & 4 & -2 \\
\hline 13 & 2.7660 & 0 & 3 & 1 & 12 & 2.0948 & 3 & 3 & 1 & 3 & 1.5739 & 1 & 3 & -3 \\
\hline 35 & 2.7428 & 3 & 1 & -1 & 3 & 2.0839 & 0 & 3 & 2 & 4 & 1.5674 & 5 & 0 & 2 \\
\hline 30 & 2.7063 & 3 & 2 & 0 & 2 & 2.0459 & 1 & 3 & -2 & 2 & 1.5630 & 6 & 1 & -1 \\
\hline 27 & 2.6870 & 2 & 3 & 0 & 3 & 2.0283 & 1 & 3 & 2 & 12 & 1.5495 & 1 & 5 & 2 \\
\hline 13 & 2.6838 & 1 & 3 & -1 & 14 & 2.0070 & 4 & 2 & 1 & 12 & 1.5261 & 2 & 6 & 0 \\
\hline 15 & 2.6584 & 3 & 1 & 1 & 11 & 1.9548 & 3 & 2 & -2 & 7 & 1.5198 & 1 & 6 & 1 \\
\hline 14 & 2.6512 & 1 & 3 & 1 & 19 & 1.9396 & 3 & 4 & 0 & 3 & 1.5131 & 4 & 5 & 0 \\
\hline 15 & 2.6023 & 1 & 0 & 2 & 7 & 1.9294 & 5 & 1 & 0 & 5 & 1.4935 & 2 & 5 & 2 \\
\hline 13 & 2.5630 & 1 & 1 & -2 & 8 & 1.8939 & 3 & 2 & 2 & 7 & 1.4696 & 4 & 5 & -1 \\
\hline 3 & 2.5179 & 1 & 1 & 2 & 8 & 1.8939 & 1 & 5 & 0 & 10 & 1.4639 & 2 & 6 & 1 \\
\hline 13 & 2.4562 & 4 & 0 & 0 & 13 & 1.8556 & 4 & 3 & -1 & 2 & 1.4560 & 5 & 4 & 1 \\
\hline 5 & 2.4333 & 2 & 3 & -1 & 6 & 1.8377 & 5 & 1 & -1 & 7 & 1.4307 & 6 & 0 & -2 \\
\hline 5 & 2.4333 & 2 & 0 & -2 & 12 & 1.8298 & 4 & 1 & -2 & & & & & \\
\hline 4 & 2.4085 & 0 & 4 & 0 & 4 & 1.8226 & 5 & 2 & 0 & & & & & \\
\hline
\end{tabular}

Ta b le 14 Unit-cell parameters of UNK6 (for monoclinic space group $P 2 / c$ ) and comparison with data for arthurite group minerals

\begin{tabular}{|l|cccccc|}
\hline & UNK6 & arthurite & ojuelaite & cobaltarthurite & whitmoreite & earlshannonite \\
& $* 1$ & $* 2$ & $* 3$ & $* 4$ & $* 5$ & Mn \\
$A$ & $\mathrm{Cu}$ & $\mathrm{Cu}$ & $\mathrm{Zn}$ & $\mathrm{Co}$ & $\mathrm{Fe}$ & $\mathrm{Fe}$ \\
$B$ & $\mathrm{Fe}$ & $\mathrm{Fe}$ & $\mathrm{Fe}$ & $\mathrm{Fe}$ & $\mathrm{Fe}$ & $\mathrm{P}$ \\
$T$ & $\mathrm{P}$ & $\mathrm{As}$ & $\mathrm{As}$ & $\mathrm{As}$ & $\mathrm{P}$ & $9.91(1)$ \\
\hline$a[\AA]$ & $9.839(2)$ & $10.189(2)$ & $10.237(1)$ & $10.2635(9)$ & $10.00(2)$ & $9.669(8)$ \\
$b[\AA]$ & $9.636(2)$ & $9.649(2)$ & $9.662(3)$ & $9.7028(8)$ & $9.73(2)$ & $5.455(9)$ \\
$c[\AA]$ & $5.471(1)$ & $5.598(1)$ & $5.562(1)$ & $5.5711(5)$ & $5.471(8)$ & $93.95(9)$ \\
$B\left[{ }^{\circ}\right]$ & $92.23(2)$ & $92.16(2)$ & $94.36(1)$ & $94.207(1)$ & $93.8(1)$ & 521.4 \\
$V\left[\AA^{3}\right]$ & $518.3(1)$ & $549.9(2)$ & 548.5 & $553.30(8)$ & 531.16 & \\
\hline
\end{tabular}

*1 - Krásno (this paper); *2 - Keller - Hess (1978); *3 Hughes et al. (1996); *4 - Kampf (2005); *5 - Moore et al. (1974); *6- Peacor et al. (1984). 
Table 15 Ideal composition of arthurite group minerals

\begin{tabular}{|l|llll|}
\hline & $A$ & $B$ & $T$ & \\
\hline arthurite & $\mathrm{Cu}$ & $\mathrm{Fe}$ & $\mathrm{As}$ & Davis - Hey $(1964)$ \\
cobaltarthurite & $\mathrm{Co}$ & $\mathrm{Fe}$ & $\mathrm{As}$ & Jambor et al. $(2002)$ \\
ojuelaite & $\mathrm{Zn}$ & $\mathrm{Fe}$ & $\mathrm{As}$ & Cesbron et al. $(1981)$ \\
earlshannonite & $\mathrm{Mn}$ & $\mathrm{Fe}$ & $\mathrm{P}$ & Peacor et al. $(1984)$ \\
whitmoreite & $\mathrm{Fe}$ & $\mathrm{Fe}$ & $\mathrm{P}$ & Moore et al. $(1974)$ \\
UNK6 & $\mathrm{Cu}$ & $\mathrm{Fe}$ & $\mathrm{P}$ & this paper \\
UNK7 & $\mathrm{Zn}$ & $\mathrm{Fe}$ & $\mathrm{P}$ & this paper \\
UNK8 & $\mathrm{Fe}$ & $\mathrm{Al}$ & $\mathrm{P}$ & this paper \\
\hline
\end{tabular}

The anion tetrahedral $T$ position may contain minor $\mathrm{S}$ and $\mathrm{Si}$, next to the dominating As and P. Davis - Hey (1969) found 0.40 apfu $\mathrm{P}$ and 0.22 apfu $\mathrm{S}$ besides 1.38 apfu As in arthurite; Jambor et al. (2002) reported P contents to 0.04 apfu and $\mathrm{S}$ to 0.01 apfu for cobaltarthurite. Frost et al. (2003) found 0.55 apfu As and 1.46 apfu $\mathrm{P}$ in arthurite from Hingston Down, Consols Mine, Calstock, Cornwall (Great Britain). According to these data, the relation is obviously $\mathrm{P}>\mathrm{As}$ and this mineral should

Table 16 Chemical composition of $\boldsymbol{U N K \boldsymbol { K }}$ (in wt. \%)

\begin{tabular}{|c|c|c|c|c|c|c|c|c|c|c|c|c|c|}
\hline & \multicolumn{4}{|c|}{ aggregates } & \multicolumn{5}{|c|}{ crystals } & \multicolumn{4}{|c|}{ tables } \\
\hline & mean & 1 & 2 & 3 & 4 & mean & 5 & 6 & 7 & mean & 8 & 9 & 10 \\
\hline $\mathrm{Na}_{2} \mathrm{O}$ & 0.01 & 0.00 & 0.00 & 0.06 & 0.00 & 0.03 & 0.04 & 0.00 & 0.00 & 0.00 & 0.00 & 0.00 & \\
\hline $\mathrm{K}_{2} \stackrel{2}{\mathrm{O}}$ & 0.01 & 0.02 & 0.00 & 0.00 & 0.02 & 0.02 & 0.05 & 0.04 & 0.00 & 0.00 & 0.00 & 0.00 & \\
\hline $\mathrm{CuO}$ & 21.04 & 20.80 & 20.36 & 20.06 & 21.82 & 18.03 & 19.29 & 18.00 & 15.91 & 21.36 & 20.27 & 22.32 & 16.88 \\
\hline $\mathrm{MnO}$ & 0.02 & 0.00 & 0.13 & 0.00 & 0.00 & 0.02 & 0.00 & 0.00 & 0.00 & 0.01 & 0.02 & 0.00 & \\
\hline $\mathrm{ZnO}$ & 0.54 & 0.22 & 0.84 & 0.90 & 0.95 & 1.11 & 1.08 & 0.28 & 1.00 & 0.28 & 0.19 & 0.26 & \\
\hline $\mathrm{BaO}$ & 0.00 & 0.00 & 0.00 & 0.00 & 0.00 & 0.06 & 0.22 & 0.00 & 0.00 & 0.00 & 0.00 & 0.00 & \\
\hline $\mathrm{CaO}$ & 0.08 & 0.05 & 0.03 & 0.04 & 0.11 & 0.53 & 0.31 & 0.03 & 0.03 & 0.05 & 0.05 & 0.07 & \\
\hline $\mathrm{PbO}$ & 0.01 & 0.07 & 0.00 & 0.03 & 0.05 & 0.05 & 0.00 & 0.00 & 0.00 & 0.06 & 0.03 & 0.16 & \\
\hline $\mathrm{MgO}$ & 0.04 & 0.08 & 0.00 & 0.10 & 0.11 & 0.12 & 0.01 & 0.08 & 0.25 & 0.00 & 0.00 & 0.00 & \\
\hline $\mathrm{FeO}^{*}$ & 0.00 & 0.00 & 0.00 & 0.00 & 0.00 & 0.00 & 0.00 & 0.02 & 0.42 & 0.00 & 0.00 & 0.00 & \\
\hline $\mathrm{Fe}_{2} \mathrm{O}_{3} *$ & 29.68 & 30.13 & 30.75 & 30.11 & 30.28 & 34.53 & 32.75 & 36.26 & 35.81 & 29.86 & 29.64 & 31.06 & 33.88 \\
\hline $\mathrm{Al}_{2}^{2} \mathrm{O}_{3}^{3}$ & 0.39 & 0.25 & 0.34 & 0.43 & 0.57 & 1.07 & 2.74 & 0.52 & 0.25 & 0.46 & 0.44 & 0.42 & \\
\hline $\mathrm{SiO}_{2}$ & 0.04 & 0.07 & 0.08 & 0.00 & 0.03 & 0.04 & 0.11 & 0.00 & 0.00 & 0.04 & 0.02 & 0.07 & \\
\hline $\mathrm{TiO}_{2}^{2}$ & 0.00 & 0.00 & 0.00 & 0.00 & 0.00 & 0.21 & 0.51 & 0.00 & 0.00 & 0.00 & 0.00 & 0.00 & \\
\hline $\mathrm{As}_{2} \mathrm{O}_{5}$ & 10.66 & 16.81 & 6.74 & 5.46 & 3.70 & 5.95 & 1.64 & 10.43 & 7.26 & 21.58 & 20.49 & 22.55 & \\
\hline $\mathrm{P}_{2} \mathrm{O}_{5}$ & 22.99 & 19.31 & 26.17 & 26.99 & 28.55 & 29.01 & 33.09 & 26.51 & 27.70 & 14.43 & 14.71 & 14.95 & 30.12 \\
\hline $\mathrm{SO}_{3}$ & 0.01 & 0.05 & 0.00 & 0.04 & 0.03 & 0.01 & 0.00 & 0.00 & 0.00 & 0.05 & 0.00 & 0.03 & \\
\hline $\mathrm{H}_{2} \mathrm{O}^{* * *}$ & 18.71 & 18.33 & 19.02 & 19.05 & 19.24 & 19.71 & 20.12 & 19.39 & 19.50 & 18.20 & 18.20 & 18.26 & 19.12 \\
\hline total & 104.23 & 106.19 & 104.47 & 103.27 & 105.47 & 110.49 & 111.96 & 111.55 & 108.14 & 106.37 & 104.05 & 110.15 & 100.00 \\
\hline $\mathrm{Na}$ & 0.002 & 0.000 & 0.000 & 0.009 & 0.000 & 0.004 & 0.005 & 0.000 & 0.000 & 0.000 & 0.000 & 0.000 & \\
\hline K & 0.001 & 0.002 & 0.000 & 0.000 & 0.002 & 0.002 & 0.005 & 0.004 & 0.000 & 0.000 & 0.000 & 0.000 & \\
\hline$\Sigma \mathrm{M}^{1+}$ & 0.002 & 0.002 & 0.000 & 0.009 & 0.002 & 0.007 & 0.010 & 0.004 & 0.000 & 0.000 & 0.000 & 0.000 & \\
\hline $\mathrm{Ca}$ & 0.007 & 0.004 & 0.003 & 0.003 & 0.009 & 0.041 & 0.023 & 0.003 & 0.003 & 0.004 & 0.005 & 0.006 & \\
\hline $\mathrm{Fe}^{2+}$ & 0.000 & 0.000 & 0.000 & 0.000 & 0.000 & 0.000 & 0.000 & 0.001 & 0.026 & 0.000 & 0.000 & 0.000 & \\
\hline $\mathrm{Ba}$ & 0.000 & 0.000 & 0.000 & 0.000 & 0.000 & 0.002 & 0.006 & 0.000 & 0.000 & 0.000 & 0.000 & 0.000 & \\
\hline $\mathrm{Mg}$ & 0.005 & 0.009 & 0.000 & 0.011 & 0.012 & 0.013 & 0.001 & 0.008 & 0.027 & 0.000 & 0.000 & 0.000 & \\
\hline $\mathrm{Pb}$ & 0.000 & 0.002 & 0.000 & 0.001 & 0.001 & 0.001 & 0.000 & 0.000 & 0.000 & 0.001 & 0.001 & 0.003 & \\
\hline $\mathrm{Cu}$ & 1.267 & 1.245 & 1.194 & 1.177 & 1.260 & 0.982 & 1.005 & 0.975 & 0.882 & 1.368 & 1.321 & 1.374 & 1.000 \\
\hline $\mathrm{Mn}$ & 0.001 & 0.000 & 0.009 & 0.000 & 0.000 & 0.001 & 0.000 & 0.000 & 0.000 & 0.000 & 0.001 & 0.000 & \\
\hline $\mathrm{Zn}$ & 0.032 & 0.013 & 0.048 & 0.052 & 0.054 & 0.059 & 0.055 & 0.015 & 0.054 & 0.017 & 0.012 & 0.015 & \\
\hline$\Sigma \mathrm{A}$ & 1.312 & 1.273 & 1.254 & 1.244 & 1.336 & 1.099 & 1.090 & 1.002 & 0.992 & 1.392 & 1.340 & 1.399 & 1.000 \\
\hline $\mathrm{Al}^{3+}$ & 0.037 & 0.023 & 0.031 & 0.039 & 0.052 & 0.091 & 0.222 & 0.044 & 0.022 & 0.045 & 0.045 & 0.041 & \\
\hline $\mathrm{Fe}^{3+}$ & 1.781 & 1.797 & 1.796 & 1.761 & 1.742 & 1.875 & 1.701 & 1.956 & 1.978 & 1.906 & 1.924 & 1.905 & 1.999 \\
\hline $\mathrm{Ti}^{4+}$ & 0.000 & 0.000 & 0.000 & 0.000 & 0.000 & 0.011 & 0.027 & 0.000 & 0.000 & 0.000 & 0.000 & 0.000 & \\
\hline$\Sigma \mathrm{B}$ & 1.817 & 1.820 & 1.828 & 1.800 & 1.793 & 1.978 & 1.950 & 2.000 & 2.000 & 1.952 & 1.969 & 1.946 & 1.999 \\
\hline $\mathrm{Si}$ & 0.003 & 0.006 & 0.006 & 0.000 & 0.002 & 0.003 & 0.008 & 0.000 & 0.000 & 0.004 & 0.002 & 0.005 & \\
\hline As & 0.444 & 0.696 & 0.274 & 0.222 & 0.148 & 0.225 & 0.059 & 0.391 & 0.279 & 0.957 & 0.924 & 0.961 & \\
\hline $\mathrm{P}$ & 1.552 & 1.295 & 1.720 & 1.776 & 1.848 & 1.772 & 1.933 & 1.609 & 1.721 & 1.036 & 1.074 & 1.031 & 2.000 \\
\hline S & 0.001 & 0.003 & 0.000 & 0.002 & 0.002 & 0.001 & 0.000 & 0.000 & 0.000 & 0.003 & 0.000 & 0.002 & \\
\hline$\Sigma \mathrm{T}$ & 2.000 & 2.000 & 2.000 & 2.000 & 2.000 & 2.000 & 2.000 & 2.000 & 2.000 & 2.000 & 2.000 & 2.000 & 2.000 \\
\hline $\mathrm{H}$ & 10.076 & 9.995 & 9.987 & 9.899 & 10.049 & 10.154 & 10.066 & 10.008 & 9.982 & 10.646 & 10.588 & 10.652 & 9.999 \\
\hline $\mathrm{OH}$ & 2.076 & 2.005 & 1.985 & 1.899 & 2.053 & 2.146 & 2.059 & 2.007 & 1.984 & 2.638 & 2.585 & 2.631 & 1.999 \\
\hline $\mathrm{H}_{2} \mathrm{O}$ & 4.000 & 3.995 & 4.001 & 4.000 & 3.998 & 4.004 & 4.003 & 4.001 & 3.999 & 4.004 & 4.001 & 3.997 & 4.000 \\
\hline
\end{tabular}

Empirical formulas were calculated on the basis of $(\mathrm{P}+\mathrm{As}+\mathrm{Si}+\mathrm{S})=2$;

* calculation of $\mathrm{Fe}_{\text {tot }}$ to $\mathrm{Fe}^{2+}$ and $\mathrm{Fe}^{3+}$ is based on the assumption that $\mathrm{Fe}^{3+}$ (jointly with $\mathrm{Al}^{3+}$ and $\mathrm{Ti}^{4+}$ ) preferentially occupied the $\mathrm{B}^{3+}$ position; only $\mathrm{Fe}$ in surplus, above 2 apfu, enters the $\mathrm{A}^{2+}$ position as $\mathrm{Fe}^{2+}$; ** $\mathrm{H}_{2} \mathrm{O}$ content calculated on the basis of the general formula $\left(\mathrm{H}_{2} \mathrm{O}=4\right)$ and charge balance. 1-9 - selected spot analyses of $\boldsymbol{U N K \boldsymbol { N }}$, 10 - theoretical composition calculated from the formula $\mathrm{CuFe}_{2}^{3+}\left(\mathrm{PO}_{4}\right)_{2}(\mathrm{OH})_{2} \cdot 4 \mathrm{H}_{2} \mathrm{O}$. 
correspond to UNK6. However, the data reported by Frost et al. (2003) can be considered only as preliminary with regard to ED analysis, problems in stoichiometry, discrepancies in systematics, etc.

Chemical composition of all UNK6 types from Krásno is presented in Table 16 and in Figs 31-33. The high analytical totals in the range of 103-112 wt.\%, after inclusion of the theoretical $\mathrm{H}_{2} \mathrm{O}$ content, indicate partial

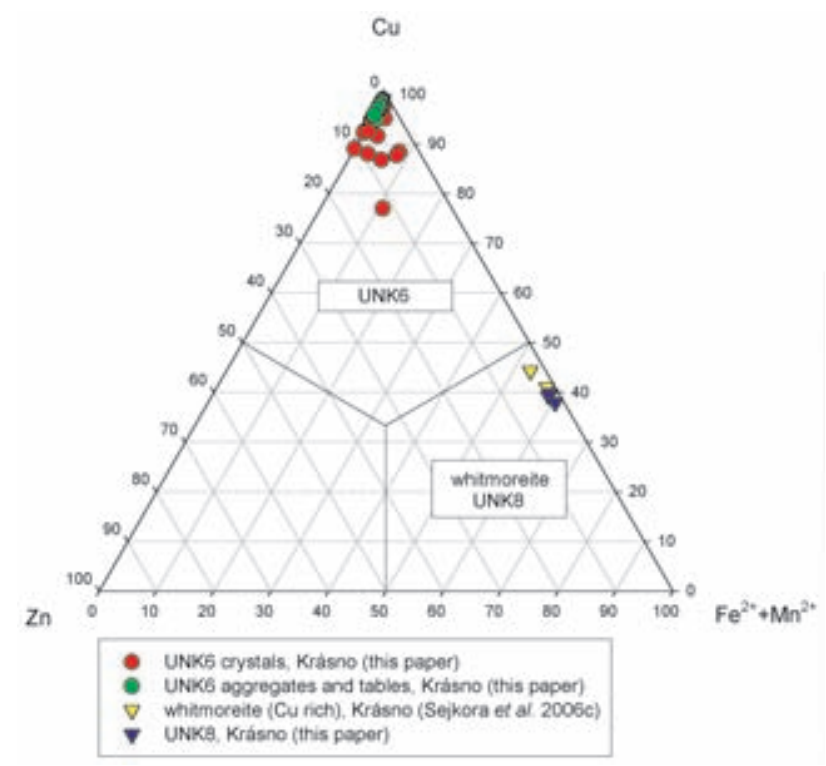

Fig. 31 Ternary plot $\mathrm{Cu}-\mathrm{Zn}-\left(\mathrm{Fe}^{2+}+\mathrm{Mn}^{2+}\right)$ of $A$-site occupancy (atomic ratios) for arthurite group mineral phases (UNK6, UNK8, Cu-rich whitmoreite) from Krásno.

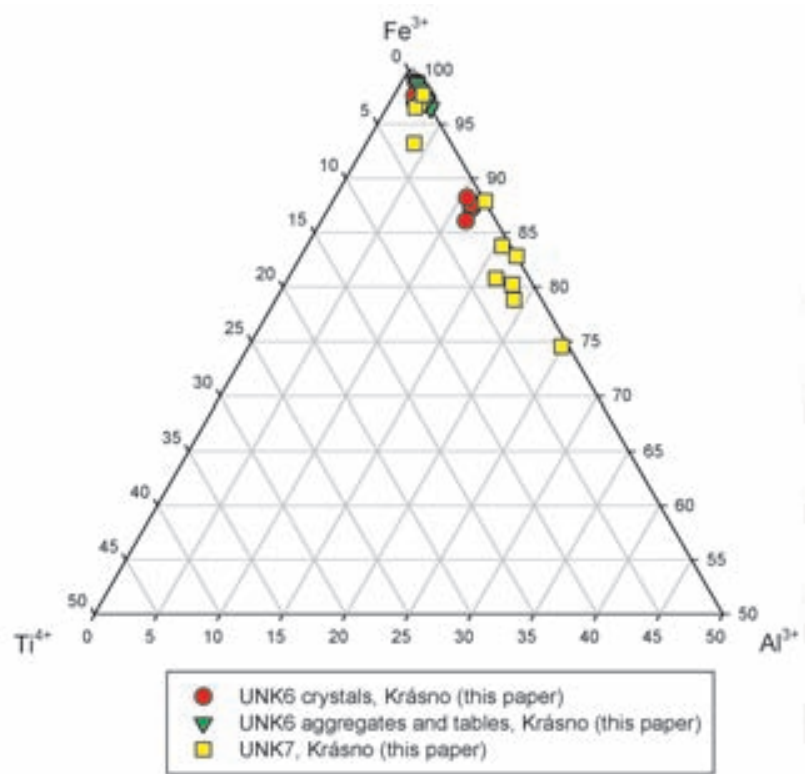

Fig. 32 Part of ternary plot $\mathrm{Fe}^{3+}-\mathrm{Ti}-\mathrm{Al}$ of $B$-site occupancy (atomic ratios) for arthurite group mineral phases (UNK6, UNK7) from Krásno dehydration of the samples studied in vacuum and their instability under electron beam. The differences in totals of the analyzed UNK6 samples correlate with the diameter of electron beam in individual analyses and do not indicate true differences in chemical composition of the studied mineral phase. $A$-site in UNK6 "aggregates" is dominated by $\mathrm{Cu}(1.12-1.40$ apfu) and contains $\mathrm{Zn}$ (0.01-0.05 apfu) and variable contents of Ca (max. 0.02 $a p f u$ ) and $\mathrm{Na}, \mathrm{Mg}$ (max. 0.01 apfu). The composition of $A$-site of UNK6 "tables" is similar to the first type: $\mathrm{Cu}$ (1.32-1.39 apfu), Zn (0.01-0.03 apfu) and $\mathrm{Ca}(\max .0 .01$ apfu). The composition of $A$-site of UNK6 "crystals" is variable (Fig. 31). In addition to dominant $\mathrm{Cu}(0.82-1.32$ apfu), there are $\mathrm{Zn}(0.01-0.13$ apfu $)$ and variable contents of Fe (max. 0.12 apfu), Ca, Mg (max. 0.04 apfu) and $\mathrm{Na}$ (max. 0.01 apfu).

The $B$-sites (Fig. 32) of $\boldsymbol{U N K \boldsymbol { 6 }}$ "aggregates" and "tables" contain $\mathrm{Fe}^{3+}(1.59-1.97 ; 1.89-1.92$ apfu) and $\mathrm{Al}$ (0.02-0.06 and 0.04-0.05 apfu, respectively). UNK6 "crystals" contain besides $\mathrm{Fe}^{3+}(1.64-1.98$ apfu), minor Ti (max. $0.04 a p f u$ ), and Al. The content of the latter varies in two ranges -0.02 to 0.07 and 0.20 to 0.23 apfu. The tetrahedral T-site of UNK6 "aggregates" and "crystals" (Fig. 33) contain dominant P (1.26-1.93 apfu), As (0.06-0.74 apfu) and minor Si (max. 0.01 apfu). In UNK6 "tables" P (1.01-1.07 apfu) just slightly predominates over As (0.92-0.99 apfu).

The average empirical formula of $\boldsymbol{U N K \boldsymbol { 6 }}$ "aggregates" (18 spot analyses) is $\left(\mathrm{Cu}_{1.27} \mathrm{Zn}_{0.03} \mathrm{Ca}_{0.01} \mathrm{Mg}_{0.01}\right)_{\Sigma 1.32}\left(\mathrm{Fe}_{1.78}\right.$ $\left.\mathrm{Al}_{0.04}\right)_{\Sigma 1.82}\left[\left(\mathrm{PO}_{4}\right)_{1.55}\left(\mathrm{AsO}_{4}\right)_{0.44}\right]_{\Sigma 1.99}(\mathrm{OH})_{2.08} \cdot 4 \mathrm{H}_{2} \mathrm{O}$; the average formula of $\boldsymbol{U N K \boldsymbol { 6 }}$ "crystals" (19 spot analyses) is

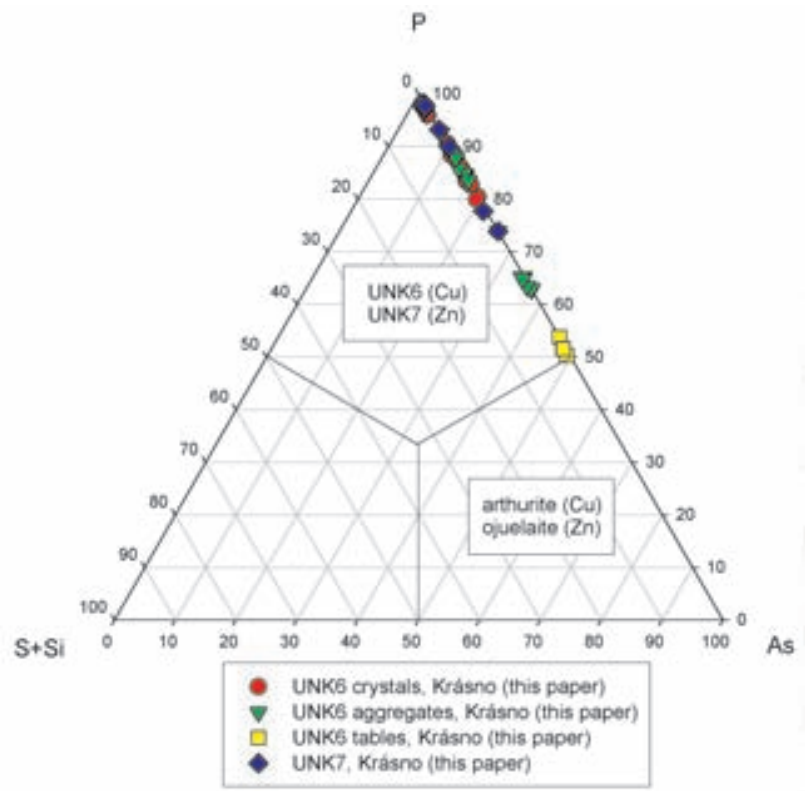

Fig. 33 Ternary plot $\mathrm{P}-(\mathrm{S}+\mathrm{Si})$-As of $T$-site occupancy (atomic ratios) for arthurite group mineral phases (UNK6, UNK 7) from Krásno. 
$\left(\mathrm{Cu}_{0.98} \mathrm{Zn}_{0.06} \mathrm{Ca}_{0.04} \mathrm{Mg}_{0.01}\right)_{\Sigma 1.09}\left(\mathrm{Fe}_{1.88} \mathrm{Al}_{0.09} \mathrm{Ti}_{0.01}\right)_{\Sigma 1.98}$ $\left[\left(\mathrm{PO}_{4}\right)_{1.77}\left(\mathrm{AsO}_{4}\right)_{0.23}\right]_{\Sigma 2.00}(\mathrm{OH})_{2.15} \cdot 4 \mathrm{H}_{2} \mathrm{O}$; the formula for UNK6 "tables" (4 spot analyses) is $\left(\mathrm{Cu}_{1.37} \mathrm{Zn}_{0.02}\right)_{\Sigma 1.39}$ $\left(\mathrm{Fe}_{1.91} \mathrm{Al}_{0.05}\right)_{\Sigma 1.96}\left[\left(\mathrm{PO}_{4}\right)_{1.04}\left(\mathrm{AsO}_{4}\right)_{0.96}\right]_{\Sigma 2.00}(\mathrm{OH})_{2.64} \cdot 4 \mathrm{H}_{2} \mathrm{O}$.

UNK 7 Zn-Fe phosphate (arthurite group) $\mathrm{ZnFe}_{2}^{3+}\left(\mathrm{PO}_{4}\right)_{2}(\mathrm{OH})_{2} \cdot 4 \mathrm{H}_{2} \mathrm{O}$

The phase $\boldsymbol{U N K} 7$ has been found in samples collected in the Huber open pit. It occurs in cavities $2-3 \mathrm{~cm}$ in diameter in former accumulations of triplite, almost completely altered to pink-brown fluorapatite (Sejkora et al. 2006c). UNK7 is associated with abundant translucent leucophosphite crystals, whitish crystals and aggregates of younger fluorapatite, abundant small, yellow-green crystals of UNK6, less common crystals of chalcosiderite-turquoise minerals, very rare snow-white skeletal crystals of UNK1 and colourless to very light yellow-green crystals of whitmoreite. Individual crystals of $U N K 7$, maximum $0.1 \mathrm{~mm}$ in size, are elongated-tabular, lathshaped, transparent to translucent, usually green with an intense vitreous lustre. Crystal morphology of this material is indistinguishable from those of UNK6 and whitmoreite. Green prismatic $\boldsymbol{U N K} 7$ crystals (max. $0.1 \mathrm{~mm}$ ) with uneven surface and greasy lustre are rare. The $\boldsymbol{U N K} 7$ phase shows, in parts of some crystals, colour zoning, including yellow-green (UNK6) and lighter domains (whitmoreite, earlshannonite, UNK8).

Owing to the very small size of $\boldsymbol{U N K} 7$, it was not possible to identify it by X-ray powder diffraction. Its classification with the arthurite group is based on stoichiometry of chemical composition and the occurrence as individual zones in the zoned crystals of the arthurite group minerals.

The chemical composition of minerals of the arthurite group can be expressed by a general formula $\mathrm{AB}_{2}\left(\mathrm{TO}_{4}\right)_{2}$ $(\mathrm{OH}, \mathrm{O})_{2} \cdot 4 \mathrm{H}_{2} \mathrm{O}$. A detailed discussion of occupancy of the individual structure sites is discussed with the phase UNK6. Variation in totals of the individual spot analyses of $\boldsymbol{U N K} 7$ in the range of 94-109 wt. \% (after inclusion of calculated $\mathrm{H}_{2} \mathrm{O}$ content) is caused mainly by variable diameter of the electron beam, selected in dependence of variable size of individual domains in the zoned crystals (Table 17).

$\mathrm{Zn}(0.35-0.75 a p f u)$ is the dominant cation in $A$-site of $\boldsymbol{U N K} 7$ (Fig. 34). $\mathrm{Fe}^{2+}$ contents are also significant (0.17-0.44 apfu), while $\mathrm{Mn}^{2+}(0-0.09$, rarely up to 0.27 apfu), $\mathrm{Mg}$ (max. 0.16 apfu), $\mathrm{Na}(\max .0 .09$ apfu) and $\mathrm{Ca}$ (max. $0.04 a p f u$ ) represent minor elements. The content of $\mathrm{Cu}$ in $A$-site of $\boldsymbol{U N K} 7$ is only $0.04 a p f u$, in conformity with the two observed trends of isomorphism in the arthurite group. These are the $\mathrm{Cu}-\mathrm{Fe}-\mathrm{Mn}$ and $\mathrm{Zn}-\mathrm{Fe}-\mathrm{Mn}$ trends, with limited substitution $\mathrm{Cu}-\mathrm{Zn}$. In the $B$-site (Fig. 32), in addition to dominating $\mathrm{Fe}^{3+}$ (1.49 to 1.95 apfu), aluminium (Al max. 0.49 apfu) and minor Ti to 0.06 apfu is present. The tetrahedral $T$-site is dominated by $P$ in the range of 1.48-1.96 apfu, in part substituted by As (0.03-0.52 apfu) and invariable minor Si and S con-
Table 17 Chemical composition of $\boldsymbol{U N K} 7$ (in wt. \%)

\begin{tabular}{|c|c|c|c|c|c|c|c|}
\hline & mean & 1 & 2 & 3 & 4 & 5 & 6 \\
\hline $\mathrm{Na}_{2} \mathrm{O}$ & 0.41 & 0.12 & 0.32 & 0.25 & 0.58 & 0.61 & \\
\hline $\mathrm{K}_{2} \mathrm{O}$ & 0.02 & 0.00 & 0.00 & 0.00 & 0.00 & 0.11 & \\
\hline $\mathrm{CuO}$ & 0.38 & 0.10 & 0.74 & 0.00 & 0.26 & 0.14 & \\
\hline $\mathrm{MnO}$ & 0.78 & 4.02 & 0.00 & 0.10 & 0.00 & 0.39 & \\
\hline $\mathrm{ZnO}$ & 10.95 & 6.03 & 8.16 & 7.49 & 12.04 & 13.12 & 17.20 \\
\hline $\mathrm{BaO}$ & 0.02 & 0.01 & 0.00 & 0.06 & 0.00 & 0.07 & \\
\hline $\mathrm{SrO}$ & 0.01 & 0.00 & 0.00 & 0.05 & 0.00 & 0.00 & \\
\hline $\mathrm{CaO}$ & 0.33 & 0.24 & 0.07 & 0.08 & 0.35 & 0.42 & \\
\hline $\mathrm{MgO}$ & 0.37 & 1.00 & 1.43 & 0.14 & 0.01 & 0.07 & \\
\hline $\mathrm{FeO}^{*}$ & 5.27 & 2.93 & 4.57 & 5.16 & 7.24 & 5.85 & \\
\hline $\mathrm{Fe}_{2} \mathrm{O}_{3} *$ & 30.44 & 32.48 & 34.72 & 28.74 & 32.09 & 29.09 & 33.75 \\
\hline $\mathrm{Al}_{2} \mathrm{O}_{3}$ & 2.80 & 0.52 & 0.52 & 0.75 & 2.82 & 3.80 & \\
\hline $\mathrm{SiO}_{2}$ & 0.04 & 0.10 & 0.00 & 0.00 & 0.00 & 0.09 & \\
\hline $\mathrm{TiO}_{2}$ & 0.40 & 0.24 & 0.00 & 0.91 & 0.00 & 0.96 & \\
\hline $\mathrm{As}_{2} \mathrm{O}_{5}$ & 3.46 & 10.52 & 3.45 & 11.58 & 1.21 & 0.86 & \\
\hline $\mathrm{P}_{2} \mathrm{O}_{5}$ & 29.12 & 23.19 & 29.45 & 20.25 & 31.71 & 31.37 & 30.00 \\
\hline $\mathrm{H}_{2} \mathrm{O} * *$ & 20.00 & 19.30 & 19.92 & 18.78 & 20.22 & 20.32 & 19.04 \\
\hline total & 104.81 & 100.80 & 103.35 & 94.34 & 108.51 & 107.27 & 100.00 \\
\hline $\mathrm{Na}$ & 0.060 & 0.019 & 0.047 & 0.042 & 0.082 & 0.088 & \\
\hline K & 0.002 & 0.000 & 0.000 & 0.000 & 0.000 & 0.010 & \\
\hline $\mathrm{Ca}$ & 0.027 & 0.020 & 0.006 & 0.007 & 0.028 & 0.033 & \\
\hline $\mathrm{Fe}^{2+}$ & 0.332 & 0.194 & 0.286 & 0.372 & 0.441 & 0.361 & \\
\hline $\mathrm{Ba}$ & 0.001 & 0.000 & 0.000 & 0.002 & 0.000 & 0.002 & \\
\hline $\mathrm{Sr}$ & 0.000 & 0.000 & 0.000 & 0.002 & 0.000 & 0.000 & \\
\hline $\mathrm{Mg}$ & 0.041 & 0.118 & 0.160 & 0.018 & 0.001 & 0.007 & \\
\hline $\mathrm{Cu}$ & 0.021 & 0.006 & 0.042 & 0.000 & 0.014 & 0.008 & \\
\hline $\mathrm{Mn}$ & 0.050 & 0.270 & 0.000 & 0.007 & 0.000 & 0.025 & \\
\hline $\mathrm{Zn}$ & 0.610 & 0.353 & 0.451 & 0.477 & 0.647 & 0.715 & 1.000 \\
\hline$A$ total & 1.144 & 0.981 & 0.990 & 0.928 & 1.212 & 1.249 & 1.000 \\
\hline $\mathrm{Al}^{3+}$ & 0.249 & 0.049 & 0.046 & 0.076 & 0.242 & 0.331 & \\
\hline $\mathrm{Fe}^{3+}$ & 1.728 & 1.937 & 1.954 & 1.864 & 1.758 & 1.616 & 1.999 \\
\hline $\mathrm{Ti}^{4+}$ & 0.023 & 0.014 & 0.000 & 0.059 & 0.000 & 0.053 & \\
\hline$B$ total & 2.000 & 2.000 & 2.000 & 2.000 & 2.000 & 2.000 & 1.999 \\
\hline $\mathrm{Si}$ & 0.003 & 0.008 & 0.000 & 0.000 & 0.000 & 0.007 & \\
\hline As & 0.137 & 0.436 & 0.135 & 0.522 & 0.046 & 0.033 & \\
\hline $\mathrm{P}$ & 1.860 & 1.556 & 1.865 & 1.478 & 1.954 & 1.960 & 2.000 \\
\hline$T$ total & 2.000 & 2.000 & 2.000 & 2.000 & 2.000 & 2.000 & 2.000 \\
\hline $\mathrm{H}$ & 10.243 & 9.954 & 9.926 & 9.878 & 10.339 & 10.440 & 9.999 \\
\hline $\mathrm{OH}$ & 2.248 & 1.949 & 1.933 & 1.873 & 2.342 & 2.446 & 1.999 \\
\hline $\mathrm{H}_{2} \mathrm{O}$ & 3.997 & 4.002 & 3.996 & 4.003 & 3.999 & 3.997 & 4.000 \\
\hline
\end{tabular}

Empirical formulas were calculated on the basis of $(\mathrm{P}+\mathrm{As}+\mathrm{Si}+\mathrm{S})=2$; 1-5 - representative analyses and mean of 11 spot analyses of $\boldsymbol{U N K} 7$; 6 - theoretical composition calculated from the formula $\mathrm{Zn}$ $\mathrm{Fe}^{3+}{ }_{2}\left(\mathrm{PO}_{4}\right)_{2}(\mathrm{OH})_{2} \cdot 4 \mathrm{H}_{2} \mathrm{O}$.

* calculation of $\mathrm{Fe}_{\text {tot }}$ to $\mathrm{Fe}^{2+}$ and $\mathrm{Fe}^{3+}$ is based on the assumption that $\mathrm{Fe}^{3+}$ preferentially (together with $\mathrm{Al}^{3+}$ and $\mathrm{Ti}^{4+}$ ) occupied the position $\mathrm{B}^{3+}$ and only the surplus $\mathrm{Fe}$ (above $2 \mathrm{pfu}$ ) enters the position $\mathrm{A}^{2+}$ as $\mathrm{Fe}^{2+}$.

** $\mathrm{H}_{2} \mathrm{O}$ content calculated from the general formula $\left(\mathrm{H}_{2} \mathrm{O}=4\right)$ and charge balance.

tents (Fig. 33). The empirical formula for the phase $\boldsymbol{U N K} 7$ (average of 11 spot analyses), calculated on the basis of $\mathrm{T}$ $=2$, is $\left(\mathrm{Zn}_{0.61} \mathrm{Fe}^{2+}{ }_{0.33} \mathrm{Na}_{0.06} \mathrm{Mn}_{0.05} \mathrm{Ca}_{0.03} \mathrm{Cu}_{0.02}\right)_{\Sigma 1.10}\left(\mathrm{Fe}^{3+}{ }_{1.73} \mathrm{Al}_{0.25}\right.$ $\left.\mathrm{Ti}_{0.02}\right)_{\Sigma 2.00}\left[\left(\mathrm{PO}_{4}\right)_{1.86}\left(\mathrm{AsO}_{4}\right)_{0.14}\right]_{\Sigma 2.00}(\mathrm{OH})_{2.25} \cdot 4 \mathrm{H}_{2} \mathrm{O}$.

\section{UNK8 FeAl phosphate (arthurite group)} $\mathrm{Fe}^{2+} \mathrm{Al}_{2}^{3+}\left(\mathrm{PO}_{4}\right)_{2}(\mathrm{OH})_{2} \cdot 4 \mathrm{H}_{2} \mathrm{O}$

$\boldsymbol{U N K \boldsymbol { 8 }}$ has been identified in cavities $2-3 \mathrm{~cm}$ in diameter in former triplite accumulations, nearly completely altered to compact pink-brown fluorapatite from the $\mathrm{Hu}-$ ber open pit (Sejkora et al. 2006c). It associates with 
abundant leucophosphite, fluorapatite, UNK6, less common UNK7, minerals of the chalcosiderite-turquoise series, exceptional whitmoreite and UNK1. UNK8 was observed as a single irregular zone 30 by $40 \mu \mathrm{m}$ in size, in a UNK6 crystal. Owing to the minimal dimensions, the phase could not be studied by X-ray powder diffraction. Its classification with the arthurite group is based on stoichiometry of chemical composition and intergrowth with UNK6.

The chemical composition of minerals of the arthurite group can be expressed by a general formula $\mathrm{AB}_{2}\left(\mathrm{TO}_{4}\right)_{2}(\mathrm{OH}, \mathrm{O})_{2} \cdot 4 \mathrm{H}_{2} \mathrm{O}$. A detailed discussion of oc-

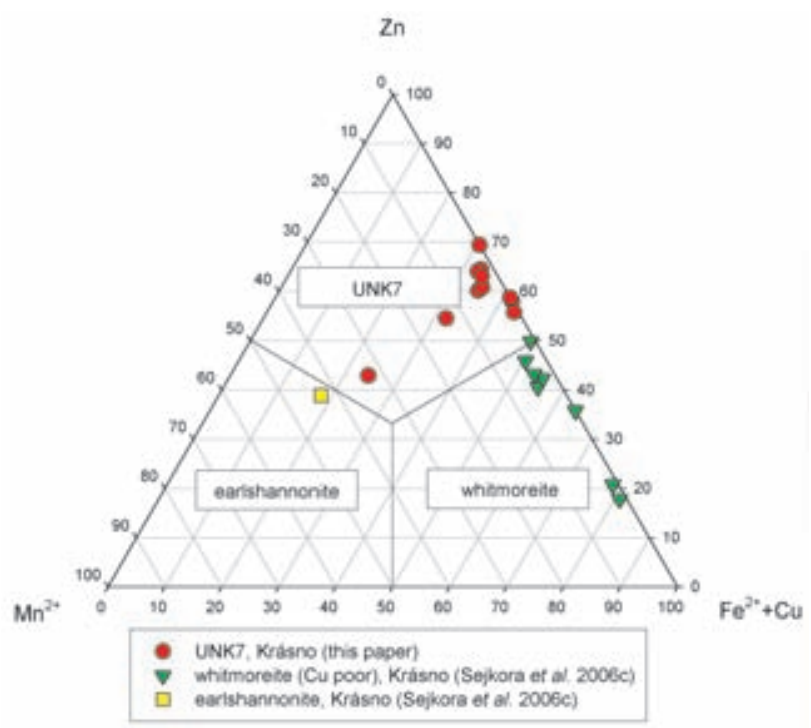

Fig. 34 Ternary plot of $\mathrm{Zn}-\mathrm{Mn}^{2+}-\left(\mathrm{Fe}^{2+}+\mathrm{Cu}\right)$ occupancy of $A$-site (atomic ratios) for arthurite group mineral phases (UNK 7 , earlshannonite and $\mathrm{Cu}$-poor whitmoreite) from Krásno.

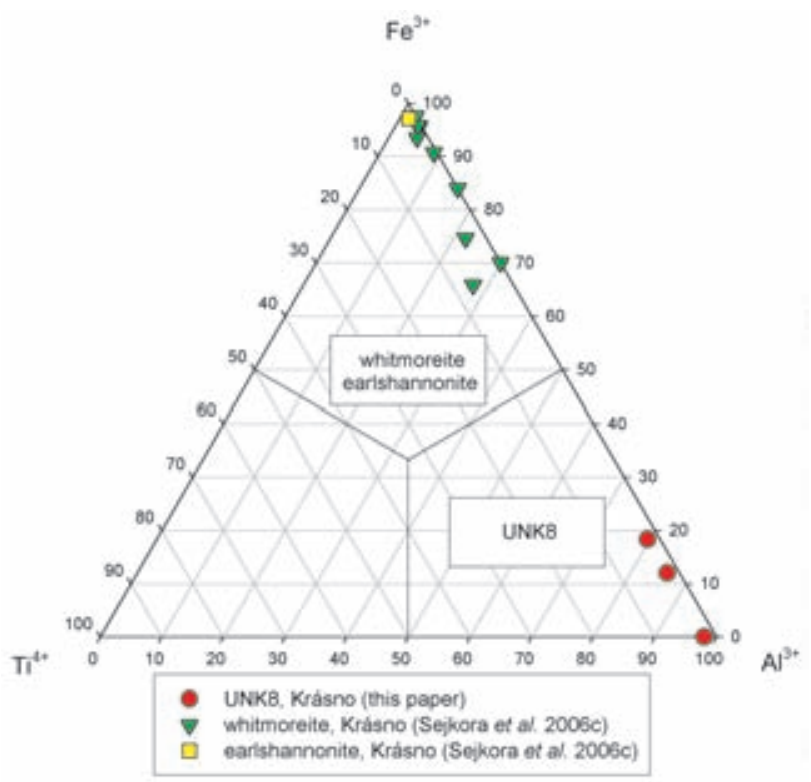

Fig. 35 Ternary plot $\mathrm{Fe}^{3+}$-Ti-Al of $B$-site occupancy (atomic ratios) for arthurite group mineral phases (UNK8, whitmoreite and earlshannonite) from Krásno.
Ta ble 18 Chemical composition of $\boldsymbol{U N K \boldsymbol { \delta }}$ (in wt. \%)

\begin{tabular}{|c|c|c|c|c|c|}
\hline & mean & 1 & 2 & 3 & 4 \\
\hline $\mathrm{Na}_{2} \mathrm{O}$ & 0.01 & 0.00 & 0.04 & 0.00 & \\
\hline $\mathrm{K}_{2} \mathrm{O}$ & 0.08 & 0.11 & 0.05 & 0.08 & \\
\hline $\mathrm{CuO}$ & 11.10 & 10.64 & 11.19 & 11.48 & \\
\hline $\mathrm{MnO}$ & 0.04 & 0.09 & 0.00 & 0.02 & \\
\hline $\mathrm{ZnO}$ & 0.50 & 0.43 & 0.61 & 0.48 & \\
\hline $\mathrm{BaO}$ & 0.10 & 0.04 & 0.25 & 0.02 & \\
\hline $\mathrm{SrO}$ & 0.10 & 0.17 & 0.12 & 0.02 & \\
\hline $\mathrm{CaO}$ & 0.14 & 0.11 & 0.19 & 0.12 & \\
\hline $\mathrm{PbO}$ & 0.03 & 0.00 & 0.10 & 0.00 & \\
\hline $\mathrm{FeO}^{*}$ & 15.23 & 14.12 & 15.07 & 16.38 & 17.70 \\
\hline $\mathrm{Fe}_{2} \mathrm{O}_{3} *$ & 3.54 & 6.53 & 4.23 & 0.00 & \\
\hline $\mathrm{Al}_{2} \mathrm{O}_{3}$ & 19.92 & 18.12 & 19.33 & 22.32 & 25.12 \\
\hline $\mathrm{SiO}_{2}$ & 0.03 & 0.06 & 0.03 & 0.00 & \\
\hline $\mathrm{TiO}_{2}$ & 0.71 & 0.72 & 0.70 & 0.72 & \\
\hline $\mathrm{As}_{2} \mathrm{O}_{5}$ & 0.50 & 0.57 & 0.36 & 0.56 & \\
\hline $\mathrm{P}_{2} \mathrm{O}_{5}$ & 31.17 & 31.25 & 31.02 & 31.24 & 34.97 \\
\hline $\mathrm{H}_{2} \mathrm{O} * *$ & 21.64 & 21.50 & 21.58 & 21.90 & 22.20 \\
\hline total & 104.86 & 104.46 & 104.86 & 105.32 & 100.00 \\
\hline $\mathrm{Na}$ & 0.002 & 0.000 & 0.005 & 0.000 & \\
\hline K & 0.008 & 0.010 & 0.005 & 0.008 & \\
\hline $\mathrm{Ca}$ & 0.011 & 0.009 & 0.015 & 0.009 & \\
\hline $\mathrm{Fe}^{2+}$ & 0.955 & 0.881 & 0.952 & 1.024 & 1.000 \\
\hline $\mathrm{Ba}$ & 0.003 & 0.001 & 0.007 & 0.001 & \\
\hline $\mathrm{Sr}$ & 0.004 & 0.007 & 0.005 & 0.001 & \\
\hline $\mathrm{Pb}$ & 0.001 & 0.000 & 0.002 & 0.000 & \\
\hline $\mathrm{Cu}$ & 0.629 & 0.600 & 0.638 & 0.648 & \\
\hline $\mathrm{Mn}$ & 0.002 & 0.006 & 0.000 & 0.001 & \\
\hline $\mathrm{Zn}$ & 0.028 & 0.023 & 0.034 & 0.026 & \\
\hline$A$ total & 1.642 & 1.536 & 1.665 & 1.719 & 1.000 \\
\hline $\mathrm{Al}^{3+}$ & 1.760 & 1.593 & 1.720 & 1.968 & 2.000 \\
\hline $\mathrm{Fe}^{3+}$ & 0.200 & 0.367 & 0.240 & 0.000 & \\
\hline $\mathrm{Ti}^{4+}$ & 0.040 & 0.040 & 0.039 & 0.040 & \\
\hline$B$ total & 2.000 & 2.000 & 2.000 & 2.008 & 2.000 \\
\hline $\mathrm{Si}$ & 0.002 & 0.004 & 0.003 & 0.000 & \\
\hline As & 0.019 & 0.022 & 0.014 & 0.022 & \\
\hline $\mathrm{P}$ & 1.978 & 1.973 & 1.983 & 1.978 & 2.000 \\
\hline$T$ total & 2.000 & 2.000 & 2.000 & 2.000 & 2.000 \\
\hline $\mathrm{H}$ & 11.308 & 11.102 & 11.354 & 11.507 & 10.000 \\
\hline $\mathrm{OH}$ & 3.313 & 3.099 & 3.356 & 3.509 & 2.000 \\
\hline $\mathrm{H}_{2} \mathrm{O}$ & 3.997 & 4.002 & 3.999 & 3.999 & 4.000 \\
\hline
\end{tabular}

Empirical formulas are calculated on the basis of $(\mathrm{P}+\mathrm{As}+\mathrm{Si}+\mathrm{S})=2$; Average composition and 1,2,3-spot analyses of $\boldsymbol{U N K} 8$; 4 - theoretical composition calculated from the formula $\mathrm{Fe}^{2+} \mathrm{Al}_{2}^{3+}\left(\mathrm{PO}_{4}\right)_{2}(\mathrm{OH})_{2} \cdot 4 \mathrm{H}_{2} \mathrm{O}$.

* calculation of $\mathrm{Fe}_{\text {tot }}$ to $\mathrm{Fe}^{2+}$ and $\mathrm{Fe}^{3+}$ is based on the assumption that $\mathrm{Fe}^{3+}$ preferentially (together with $\mathrm{Al}^{3+}$ and $\mathrm{Ti}^{4+}$ ) occupied the position $\mathrm{B}^{3+}$ and only the surplus $\mathrm{Fe}$ (above $2 \mathrm{pfu}$ ) enters the position $\mathrm{A}^{2+}$ as $\mathrm{Fe}^{2+}$. ** $\mathrm{H}_{2} \mathrm{O}$ content calculated from the general formula $\left(\mathrm{H}_{2} \mathrm{O}=4\right)$ and charge balance.

cupancy of the individual structure sites is discussed with the phase UNK6. Variation in totals of the individual spot analyses of $\boldsymbol{U N K \boldsymbol { \delta }}$ in the range of 94-106 wt. \% (after inclusion of calculated $\mathrm{H}_{2} \mathrm{O}$ content) indicate dehydration of the studied sample in vacuum and its instability under electron beam (Table 18). The $A$-site in $\boldsymbol{U N K \boldsymbol { 8 }}$ (Fig. 31) is dominated by $\mathrm{Fe}^{2+}(0.88-1.02$ apfu), accompanied by $\mathrm{Cu}(0.60-0.65$ apfu), minor $\mathrm{Zn}$ (max. 0.03 $a p f u)$, and $\mathrm{Ca}(\max .0 .01$ apfu). The dominant element in the $B$-site (Fig. 35) is Al (1.59-1.97) apfu and $\mathrm{Fe}^{3+}$ (max. $0.37 a p f u$ ), and minor Ti (max. $0.04 a p f u)$. The tetrahedral $T$-site (Fig. 36) is nearly completely occupied by 


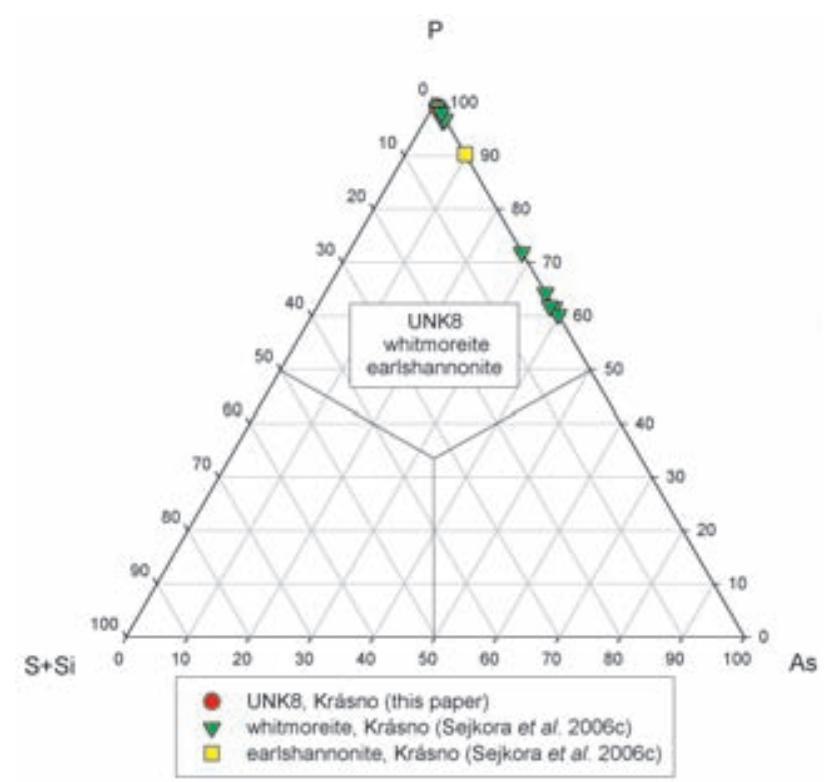

Fig. 36 Ternary plot P-(S+Si)-As of $T$-site occupancy (atomic ratios) for arthurite group mineral phases $(\boldsymbol{U N K \boldsymbol { K }}$, whitmoreite and earlshannonite) from Krásno.

P (1.97-1.98 apfu) with minor substitution of As in the range of 0.01 to 0.02 apfu. The empirical formula of $\boldsymbol{U N K} \boldsymbol{8}$ (average of three spot analyses) on the basis $\mathrm{T}=2.00$ is $\left(\mathrm{Fe}^{2+}{ }_{0.96} \mathrm{Cu}_{0.63} \mathrm{Zn}_{0.03} \mathrm{Ca}_{0.01}\right)_{\Sigma 1.63}\left(\mathrm{Al}_{1.76} \mathrm{Fe}^{3+}{ }_{0.20} \mathrm{Ti}_{0.04}\right)_{\Sigma 2.00}$ $\left[\left(\mathrm{PO}_{4}\right)_{1.98}\left(\mathrm{AsO}_{4}\right)_{0.02}\right)_{\Sigma 2.00}(\mathrm{OH})_{3.31} \cdot 4 \mathrm{H}_{2} \mathrm{O}$

\author{
UNK9 Fe-Mn phosphate - \\ $\left(\mathrm{Mn}^{2+}, \mathrm{Fe}^{2+}\right)_{2}\left(\mathrm{Fe}^{3+}, \mathrm{Al}\right)_{3}\left(\mathrm{PO}_{4}\right)_{3}(\mathrm{OH})_{4} \cdot \mathrm{H}_{2} \mathrm{O}$
}

UNK9 is fairly abundant in several samples of phosphate accumulations collected at the $5^{\text {th }}$ level of the Huber shaft (Sejkora et al. 2006c). It occurs in parts where triplite is nearly completely replaced by younger minerals of the rockbridgeite - frondelite series. These black phosphates with greenish or brownish shade are in turn partly altered, giving rise to aggregates of blue-grey phosphosiderite. In some specimens, UNK9 is younger than phosphosiderite, in other specimens it is older, as it is overgrown by younger phosphosiderite. The youngest minerals in this association are light pink morinite, beraunite grains and purple-red strengite, acicular crystals of natrodufrénite and compact aggregates of K-Mn oxide enclosing semispheroidal fluorite.

UNK 9 typically occurs as light to dark brown tabular aggregates of crystals (Fig. 37), 2-3 $\mathrm{mm}$ in size, in minor cavities 2 to $3 \mathrm{~mm}$ in diameter. The aggregates are composed of imperfect (Figs 38 and 39) transparent, tabular to scaly crystals up to $0.5 \mathrm{~mm}$ long, with a vitreous to pearly lustre. The phase has a yellow-brown streak with a slight green shade.

X-ray powder data for $\boldsymbol{U N K \boldsymbol { 9 }}$ from Krásno (Table 19) correspond well to data for the unnamed Fe-Mn "dufrénite-like" mineral from Buranga, Rwanda (Knorring Sahama 1982). However, it is not possible to index $\mathrm{X}$-ray powder diffraction data correctly on the basis of

Fig. 37 Dark brown crystalline aggregates of UNK9, Krásno. Width of the area shown $3.5 \mathrm{~mm}$. Nikon SMZ1500, photograph by J. Sejkora.

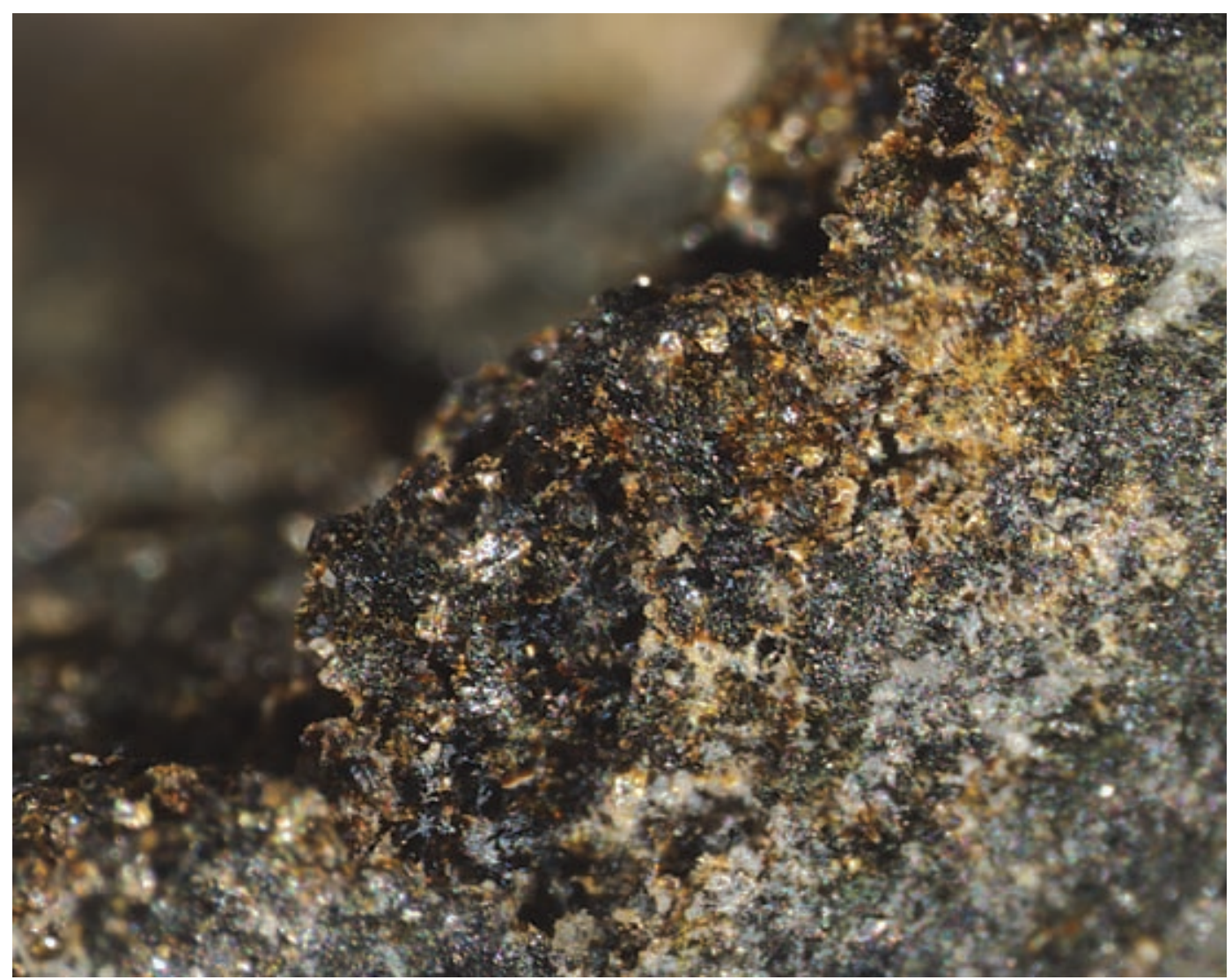


Table 19 X-ray powder diffraction pattern of $\boldsymbol{U N K \boldsymbol { M }}$

\begin{tabular}{|c|c|c|c|c|c|c|c|c|c|c|c|}
\hline$I_{r e l}$ & $d$ & $I_{r e l}^{*}$ & $d^{*}$ & $I_{r e l}$ & $d$ & $I_{r e l} *$ & $d^{*}$ & $I_{r e l}$ & $d$ & $I_{r e l}^{*}$ & $d^{*}$ \\
\hline \multirow[t]{2}{*}{71} & 6.916 & 40 & 6.93 & 87 & 3.016 & 60 & 3.020 & 40 & 2.1154 & 20 & 2.120 \\
\hline & & 20 & 6.43 & 33 & 2.942 & 20 & 2.950 & 28 & 2.0700 & 20 & 2.080 \\
\hline 13 & 5.185 & 40 & 5.22 & 9 & 2.879 & 20 & 2.880 & 36 & 2.0301 & 20 & 2.040 \\
\hline 17 & 4.843 & 60 & 4.86 & 42 & 2.806 & 20 & 2.820 & 7 & 1.9820 & 20 & 1.980 \\
\hline 14 & 4.363 & 20 & 4.43 & 10 & 2.764 & 20 & 2.750 & 36 & 1.9432 & 40 & 1.950 \\
\hline 35 & 4.231 & 40 & 4.23 & 27 & 2.701 & & & 10 & 1.8812 & 20 & 1.880 \\
\hline 56 & 4.021 & 20 & 4.03 & 66 & 2.625 & 60 & 2.630 & 9 & 1.8506 & 20 & 1.850 \\
\hline 29 & 3.883 & 20 & 3.88 & 12 & 2.504 & 10 & 2.510 & & & 20 & 1.820 \\
\hline 42 & 3.730 & 40 & 3.734 & 11 & 2.4466 & 60 & 2.440 & 26 & 1.7855 & 20 & 1.790 \\
\hline 98 & 3.447 & 100 & 3.464 & 19 & 2.2829 & 20 & 2.300 & 29 & 1.7417 & 20 & 1.750 \\
\hline 91 & 3.263 & 80 & 3.264 & & & 20 & 2.220 & 56 & 1.7227 & 40 & 1.730 \\
\hline 100 & 3.212 & 80 & 3.218 & 35 & 2.1761 & 20 & 2.180 & & & & \\
\hline 33 & 3.148 & 60 & 3.151 & 14 & 2.1552 & 20 & 2.150 & & & & \\
\hline
\end{tabular}

$I_{r e l}^{*}$ and $d^{*}$ - unnamed mineral (dufrénite-like), Buranga, Rwanda (Knorring - Sahama, 1982).

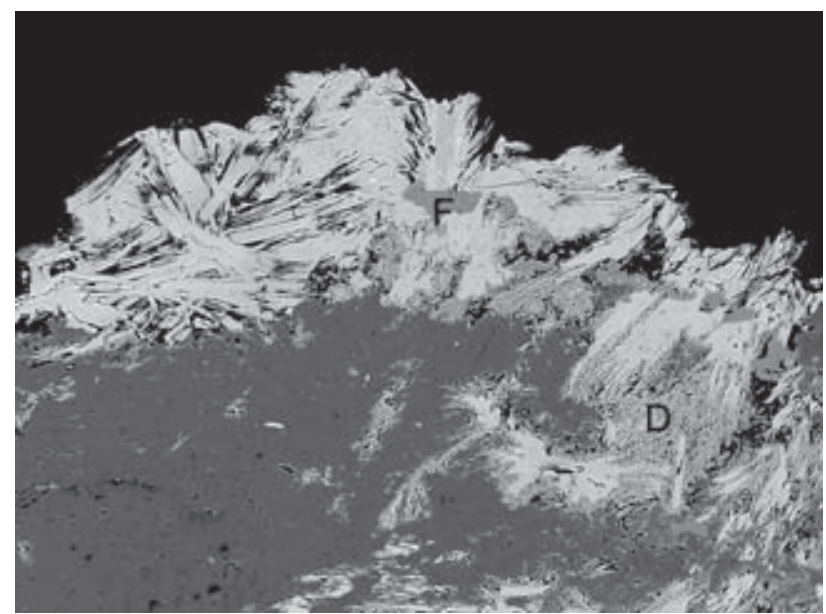

Fig. 38 Aggregates of tabular crystals of UNK 9 (light) deposited on phosphosiderite aggregate (dark), accompanied by granular fluorapatite (F) and finely fibrous Mn-rich dufrenite (D) aggregates. Width of the area shown $500 \mu \mathrm{m}$. Cameca SX100, BSE photograph by J. Sejkora and R. Škoda.

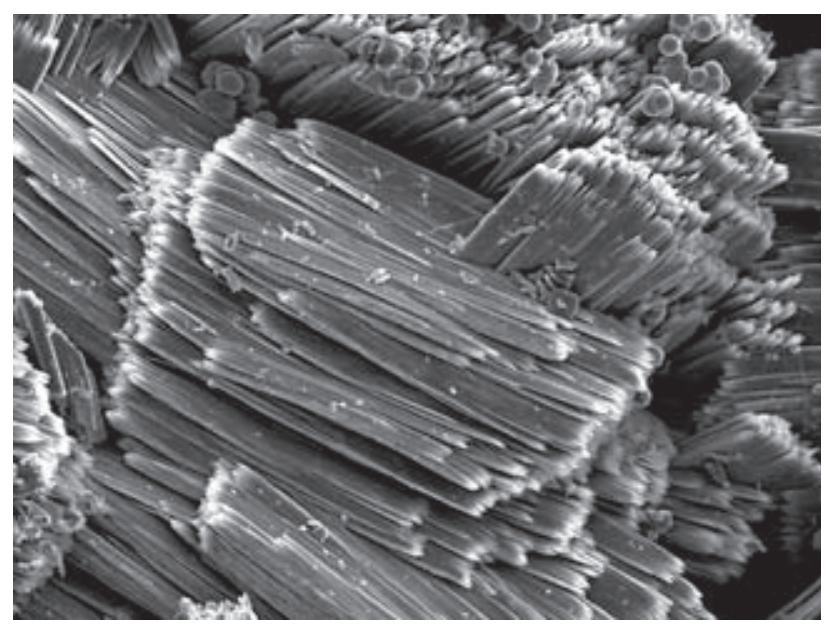

Fig. 39 Group of tabular $\boldsymbol{U N K} \mathbf{9}$ crystals, Krásno. Width of the area shown $180 \mu \mathrm{m}$. SEM photograph Jeol JSM-6380, J. Sejkora and J. Plášil. monoclinic unit-cell parameters $(a=6.44(2), b=6.93(2)$, $\mathrm{c}=19.43(3), \beta=93.25^{\circ}$ ) proposed by Knorring - Sahama (1982). However, it should be noted that the X-ray powder data for $\boldsymbol{U N K} \boldsymbol{9}$ show closer relations to those of the rockbridgeite - frondelite series than to published data for dufrénite-like minerals (dufrénite, natrodufrénite, burangaite).

Knorring - Sahama (1982) published for the phase from Buranga, analogous to $\boldsymbol{U N K} \boldsymbol{9}$, chemical analysis of major elements but did not present empirical formula. On the basis of coincidence of the X-ray powder data (of poor quality) with an unnamed "dufrénite-like" Fe phosphate, which was not analyzed (Frondel 1949), from Rothläufchen mine (Germany), they suggested that the mineral is close to dufrénite. An unnamed author of the entry No. 35-725 in the data-base of X-ray powder patterns PDF2 gave for this unnamed phosphate an ideal formula $(\mathrm{Fe}, \mathrm{Mn})_{5}\left(\mathrm{PO}_{4}\right)_{3}(\mathrm{OH})_{5} \cdot 2 \mathrm{H}_{2} \mathrm{O}$, in analogy to the dufrénite formula proposed by Frondel (1949). However, a characteristic feature of dufrénite-like minerals (dufrénite, natrodufrénite, burangaite) is the presence of $\mathrm{Na}$, $\mathrm{K}$ and $\mathrm{Ca}$, not previously discussed. In addition to differences in chemical composition, UNK9 differs from dufrénite-like minerals by X-ray diffraction pattern.

We believe that it is appropriate to express the chemical composition of $\boldsymbol{U N K} \boldsymbol{9}$ (Table 20) by a general formula $\mathrm{A}_{2} \mathrm{~B}_{3}\left(\mathrm{PO}_{4}\right)_{3}(\mathrm{OH})_{4} \cdot \mathrm{H}_{2} \mathrm{O}$. It is assumed in the calculation that $A$-site is occupied by $\mathrm{M}^{1+}$ and $\mathrm{M}^{2+}$ elements including $\mathrm{Mn}\left(\right.$ as $\left.\mathrm{Mn}^{2+}\right)$ and $\mathrm{Fe}^{2+}$. Ferrous iron is derived as surplus $\mathrm{Fe}$ above the relation $(\mathrm{Fe}+\mathrm{Al}+\mathrm{Ti})=3$ in $B$-site. A similar behaviour of $\mathrm{Mn}$ and $\mathrm{Fe}$, as observed in minerals of the rockbridgeite - frondelite series ( $\mathrm{Mn}$ is bound only as $\mathrm{Mn}^{2+} ; \mathrm{Fe}$ is dominantly ferric, but some ferrous iron is also present), is characteristic. Note that rockbridgeite - frondelite minerals occur in close association with $\boldsymbol{U N K}$ 9.

$A$-site in $\boldsymbol{U N K} \boldsymbol{9}$ (Fig. 40) is dominated by Mn (1.16 to 1.99 apfu), followed by $\mathrm{Fe}^{2+}(0-0.51 a p f u)$, minor $\mathrm{Ca}$ (0.01-0.13 apfu), Na (0-0.13, exceptionally 0.22 apfu), 
Table 20 Chemical composition of $\boldsymbol{U N K \boldsymbol { M }}$ (in wt. \%)

\begin{tabular}{|c|c|c|c|c|c|c|c|}
\hline & mean & 1 & 2 & 3 & 4 & 5 & 6* \\
\hline $\mathrm{Na}_{2} \mathrm{O}$ & 0.24 & 0.01 & 0.08 & 0.13 & 0.09 & 0.22 & 0.00 \\
\hline $\mathrm{CaO}$ & 0.39 & 0.11 & 0.13 & 0.08 & 0.05 & 0.23 & 0.00 \\
\hline $\mathrm{FeO}^{*}$ & 2.70 & 1.99 & 0.77 & 1.95 & 2.38 & 0.86 & 0.32 \\
\hline $\mathrm{BaO}$ & 0.07 & 0.11 & 0.00 & 0.00 & 0.23 & 0.00 & 0.00 \\
\hline $\mathrm{MgO}$ & 0.15 & 0.10 & 0.31 & 0.58 & 0.53 & 0.18 & 0.00 \\
\hline $\mathrm{PbO}$ & 0.06 & 0.12 & 0.00 & 0.00 & 0.06 & 0.00 & 0.00 \\
\hline $\mathrm{CuO}$ & 0.10 & 0.00 & 0.00 & 0.00 & 0.29 & 0.00 & 0.00 \\
\hline $\mathrm{MnO}$ & 17.39 & 18.86 & 20.70 & 17.93 & 18.03 & 19.39 & 21.90 \\
\hline $\mathrm{ZnO}$ & 0.24 & 0.23 & 0.20 & 0.05 & 0.03 & 0.23 & 0.00 \\
\hline $\mathrm{Fe}_{2} \mathrm{O}_{3} *$ & 33.59 & 34.62 & 31.17 & 31.20 & 30.92 & 31.82 & 34.65 \\
\hline $\mathrm{Al}_{2} \mathrm{O}_{3}$ & 0.86 & 0.45 & 2.98 & 2.32 & 2.42 & 2.27 & 0.00 \\
\hline $\mathrm{TiO}_{2}$ & 0.07 & 0.35 & 0.08 & 0.02 & 0.02 & 0.07 & 0.00 \\
\hline $\mathrm{SiO}_{2}^{2}$ & 0.04 & 0.06 & 0.00 & 0.05 & 0.00 & 0.00 & 0.00 \\
\hline $\mathrm{As}_{2} \mathrm{O}_{5}$ & 0.06 & 0.09 & 0.22 & 0.09 & 0.14 & 0.00 & 0.00 \\
\hline $\mathrm{P}_{2} \mathrm{O}_{5}$ & 31.00 & 31.54 & 31.76 & 30.87 & 30.76 & 31.46 & 30.80 \\
\hline $\mathrm{SO}_{3}$ & 0.03 & 0.04 & 0.03 & 0.00 & 0.03 & 0.06 & 0.00 \\
\hline $\mathrm{H}_{2} \mathrm{O} * *$ & 8.00 & 8.00 & 8.00 & 8.00 & 8.00 & 8.00 & 8.25 \\
\hline total & 94.99 & 96.68 & 96.42 & 93.26 & 93.97 & 94.79 & 95.92 \\
\hline $\mathrm{Na}^{+}$ & 0.053 & 0.002 & 0.017 & 0.028 & 0.019 & 0.047 & 0.000 \\
\hline $\mathrm{Ca}^{2+}$ & 0.047 & 0.013 & 0.016 & 0.010 & 0.007 & 0.027 & 0.000 \\
\hline $\mathrm{Fe}^{2+}$ & 0.257 & 0.186 & 0.072 & 0.186 & 0.229 & 0.081 & 0.031 \\
\hline $\mathrm{Ba}^{2+}$ & 0.003 & 0.005 & 0.000 & 0.000 & 0.010 & 0.000 & 0.000 \\
\hline $\mathrm{Mg}^{2+}$ & 0.026 & 0.017 & 0.051 & 0.099 & 0.091 & 0.030 & 0.000 \\
\hline $\mathrm{Pb}^{2+}$ & 0.002 & 0.004 & 0.000 & 0.000 & 0.002 & 0.000 & 0.000 \\
\hline $\mathrm{Cu}^{2+}$ & 0.008 & 0.000 & 0.000 & 0.000 & 0.025 & 0.000 & 0.000 \\
\hline $\mathrm{Mn}^{2+}$ & 1.678 & 1.786 & 1.947 & 1.736 & 1.752 & 1.846 & 2.134 \\
\hline $\mathrm{Zn}^{2+}$ & 0.020 & 0.019 & 0.016 & 0.004 & 0.002 & 0.019 & 0.000 \\
\hline$\sum A$-site & 2.094 & 2.033 & 2.118 & 2.063 & 2.137 & 2.051 & 2.165 \\
\hline $\mathrm{Fe}^{3+}$ & 2.878 & 2.912 & 2.604 & 2.685 & 2.671 & 2.693 & 3.000 \\
\hline $\mathrm{Al}^{3+}$ & 0.116 & 0.059 & 0.390 & 0.313 & 0.327 & 0.301 & 0.000 \\
\hline $\mathrm{Ti}^{4+}$ & 0.006 & 0.029 & 0.006 & 0.002 & 0.001 & 0.006 & 0.000 \\
\hline$\Sigma B$-site & 3.000 & 3.000 & 3.000 & 3.000 & 3.000 & 3.000 & 3.000 \\
\hline $\mathrm{Si}^{4+}$ & 0.005 & 0.007 & 0.000 & 0.006 & 0.000 & 0.000 & 0.000 \\
\hline $\mathrm{As}^{5+}$ & 0.004 & 0.005 & 0.013 & 0.005 & 0.008 & 0.000 & 0.000 \\
\hline $\mathrm{P}^{5+}$ & 2.989 & 2.985 & 2.985 & 2.989 & 2.989 & 2.995 & 3.000 \\
\hline $\mathrm{S}^{6+}$ & 0.003 & 0.003 & 0.002 & 0.000 & 0.003 & 0.005 & 0.000 \\
\hline$\Sigma T$-site & 3.000 & 3.000 & 3.000 & 3.000 & 3.000 & 3.000 & 3.000 \\
\hline $\mathrm{H}^{+}$ & 6.077 & 5.966 & 5.924 & 6.103 & 6.125 & 6.001 & 6.331 \\
\hline $\mathrm{OH}$ & 4.139 & 4.088 & 4.228 & 4.095 & 4.260 & 4.067 & 4.330 \\
\hline $\mathrm{H}_{2} \mathrm{O}$ & 0.969 & 0.939 & 0.848 & 1.004 & 0.933 & 0.967 & 1.001 \\
\hline
\end{tabular}

mean of all 23 spot analyses, 1-5 - representative spot analyses; 6* - unnamed mineral (dufrénite-like), Buranga, Rwanda (Knorring Sahama, 1982). Empirical formulas were calculated on the basis of $(\mathrm{P}+\mathrm{As}+\mathrm{Si}+\mathrm{S})=3$;

* calculation of $\mathrm{Fe}_{\text {tot }}$ to $\mathrm{Fe}^{2+}$ and $\mathrm{Fe}^{3+}$ is based on the assumption that $\mathrm{Fe}^{3+}$ (jointly with $\mathrm{Al}^{3+}$ and $\mathrm{Ti}^{4+}$ ) preferentially fills the $\mathrm{B}$ position; only Fe in surplus, above 3 apfu, enters the A position as $\mathrm{Fe}^{2+}$;

$\mathrm{H}_{2} \mathrm{O} * *$ content determined by thermal gravimetric analysis (Thermobalance TG-750 Stanton-Redcroft).

$\mathrm{Cu}$ and $\mathrm{Zn}$ (max. 0.04, $0.06 a p f u$, respectively), and minor $\mathrm{Ba}, \mathrm{Mg}$ and $\mathrm{Pb}$ to $0.01 \mathrm{apfu}$. The total occupancy of $A$-site in $\boldsymbol{U N K} \boldsymbol{9}$ is 1.76 to 2.34 apfu. In the $B$-site (Fig. 41) $\mathrm{Fe}^{3+}$ is the dominating cation ranging from 2.60 to 2.98 apfu. Al content is 0.02-0.12 apfu and 0.29-0.39 apfu and minor Ti to 0.03 apfu. Variable Al content in the $B$-site does not correlate with Mn content or other elements in $A$-site of $\boldsymbol{U N K}$ 9. The tetrahedral $T$-site is occupied almost exclusively by $\mathrm{P}$ (2.98-3.00 apfu), while $\mathrm{Si}$ is only to $0.02 \mathrm{apfu}$, As and $\mathrm{S}$ are to 0.01 apfu in maximum. The empirical formula for average composition ( $\mathrm{n}=23$ spot analyses) of $\boldsymbol{U N K \boldsymbol { M }}$ on the basis of $(\mathrm{P}+\mathrm{As}+\mathrm{Si}+\mathrm{S})=3$ is $\left(\mathrm{Mn}_{1.68} \mathrm{Fe}^{2+}{ }_{0.26} \mathrm{Na}_{0.05} \mathrm{Ca}_{0.04} \mathrm{Mg}_{0.03}\right.$

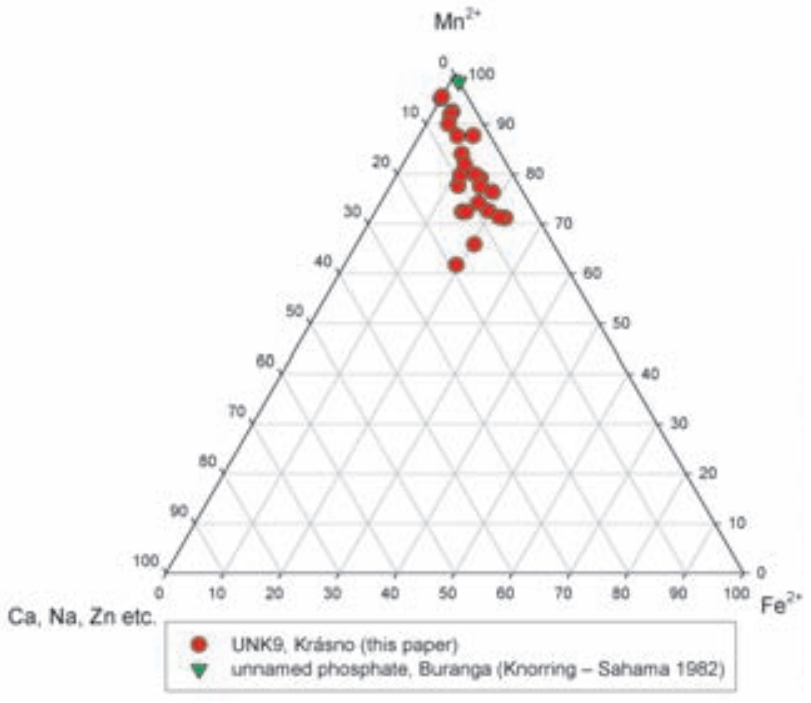

Fig. 40 Ternary plot $\mathrm{Fe}^{2+}-\mathrm{Mn}^{2+}-(\mathrm{Ca}+\mathrm{Na}+\mathrm{Zn}$ etc. $)$ of $A$-site occupancy (atomic ratios) for $\boldsymbol{U N K \boldsymbol { 9 }}$ from Krásno.

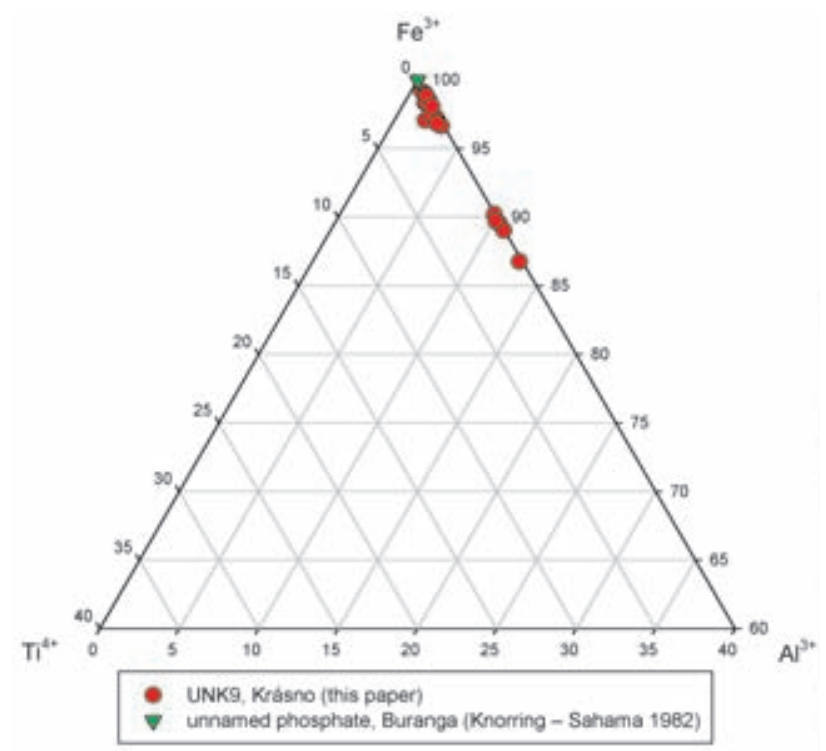

Fig. 41 Part of ternary plot $\mathrm{Al}^{3+}-\mathrm{Fe}^{3+}-\mathrm{Ti}^{4+}$ of $B$-site occupancy (atomic ratios) for $\boldsymbol{U N K} \mathbf{9}$ from Krásno.

$\left.\mathrm{Zn}_{0.02}\right)_{\Sigma 2.08}\left(\mathrm{Fe}^{3+}{ }_{2.88} \mathrm{Al}_{0.12}\right)_{\Sigma 3.00}\left(\mathrm{PO}_{4}\right)_{2.99}(\mathrm{OH})_{4.14} \cdot 0.97 \mathrm{H}_{2} \mathrm{O}$. The empirical formula for unnamed FeMn-phosphate from Buranga (Knorring - Sahama 1982), on the same basis as above, is $\left(\mathrm{Mn}_{2.13} \mathrm{Fe}_{0.03}\right)_{\Sigma 2.16} \mathrm{Fe}_{3.00}\left(\mathrm{PO}_{4}\right)_{3.00}(\mathrm{OH})_{4.33}$. $1.00 \mathrm{H}_{2} \mathrm{O}$.

\section{UNK10 Fe phosphate - $(\square, \mathrm{Cu}) \mathrm{Fe}_{6}^{3+}\left(\mathrm{PO}_{4}\right)_{2}\left(\mathrm{PO}_{3} \mathrm{OH}\right)_{2}(\mathrm{OH})_{8} \cdot 4 \mathrm{H}_{2} \mathrm{O}$}

UNK10 has been found in a single specimen from the Huber open pit, in weathered cavities 2 by $3 \mathrm{~cm}$ in size, in phosphate accumulation of light pink fluorapatite and isokite with triplite relics (Sejkora et al. 2006c). The cav- 


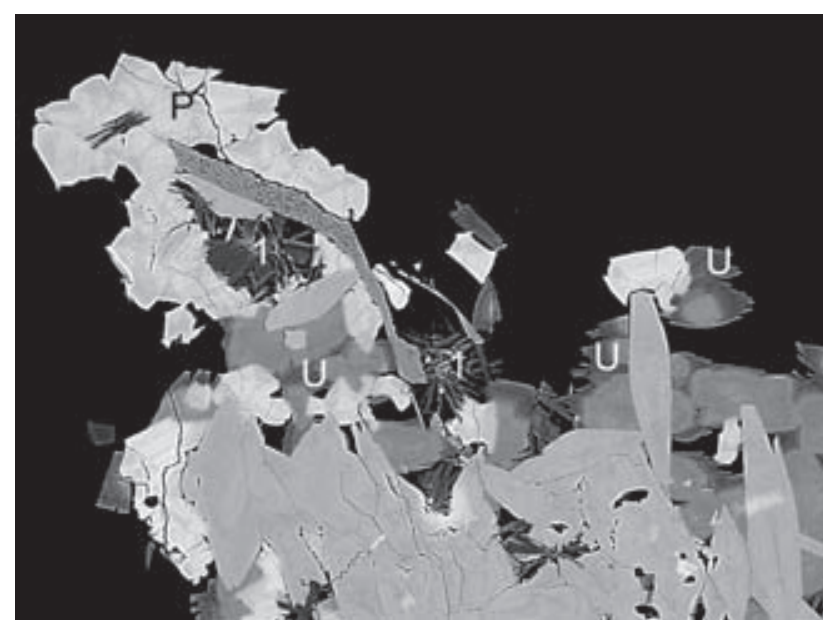

Fig. 42 Irregular zones of $\boldsymbol{U N K} \mathbf{1 0}$ (marked by U) in zoned aggregates of the turquoise group minerals, which overgrow aggregate of $U N K 3$ tabular crystals (light). Aggregates of UNK1 (tabular crystals - 1) and pharmacosiderite crystals (light $-\mathrm{P}$ ) are present at the margin. Width of the area shown $300 \mu \mathrm{m}$. Cameca SX100, BSE photograph by J. Sejkora and R. Škoda.

Table 21 Chemical composition of $\boldsymbol{U N K} 10$ (in wt. \%)

\begin{tabular}{|l|rrrr|}
\hline & mean & \multicolumn{1}{c}{1} & \multicolumn{1}{c}{2} & 3 \\
\hline $\mathrm{CaO}$ & 0.03 & 0.06 & 0.02 & 0.00 \\
$\mathrm{BaO}$ & 0.11 & 0.00 & 0.33 & 0.00 \\
$\mathrm{PbO}$ & 0.09 & 0.08 & 0.18 & 0.00 \\
$\mathrm{CuO}$ & 2.33 & 1.49 & 2.03 & 3.47 \\
$\mathrm{MnO}$ & 0.09 & 0.04 & 0.08 & 0.16 \\
$\mathrm{ZnO}$ & 0.33 & 0.16 & 0.30 & 0.54 \\
$\mathrm{Al}_{2} \mathrm{O}_{3}$ & 4.38 & 4.12 & 4.27 & 4.76 \\
$\mathrm{Fe}_{2} \mathrm{O}_{3}$ & 43.41 & 43.44 & 44.19 & 42.60 \\
$\mathrm{TiO}_{2}$ & 0.05 & 0.05 & 0.04 & 0.05 \\
$\mathrm{SiO}_{2}$ & 0.04 & 0.04 & 0.06 & 0.03 \\
$\mathrm{As}_{2} \mathrm{O}_{5}$ & 7.10 & 7.50 & 7.42 & 6.39 \\
$\mathrm{P}_{2} \mathrm{O}_{5}$ & 25.56 & 25.37 & 25.26 & 26.05 \\
$\mathrm{SO}_{3}$ & 0.07 & 0.09 & 0.00 & 0.12 \\
$\mathrm{H}_{2} \mathrm{O}^{2}$ & 16.64 & 17.09 & 16.38 & 16.51 \\
$\mathrm{total}^{2+}$ & 100.23 & 99.52 & 100.55 & 100.67 \\
$\mathrm{Ca}^{2+}$ & 0.004 & 0.010 & 0.003 & 0.000 \\
$\mathrm{Ba}^{2+}$ & 0.007 & 0.000 & 0.020 & 0.000 \\
$\mathrm{~Pb}^{2+}$ & 0.004 & 0.003 & 0.008 & 0.000 \\
$\mathrm{Cu}^{2+}$ & 0.276 & 0.176 & 0.242 & 0.411 \\
$\mathrm{Mn}^{2+}$ & 0.012 & 0.005 & 0.011 & 0.021 \\
$\mathrm{Zn}^{2+}$ & 0.039 & 0.019 & 0.035 & 0.063 \\
$\square$ & 0.658 & 0.786 & 0.682 & 0.505 \\
$\Sigma A^{2}-\mathrm{site}$ & 1.000 & 1.000 & 1.000 & 1.000 \\
$\mathrm{Fe}_{3+}$ & 5.135 & 5.127 & 5.253 & 5.026 \\
$\mathrm{Al}^{3+}$ & 0.811 & 0.761 & 0.794 & 0.879 \\
$\mathrm{Ti}^{4+}$ & 0.006 & 0.006 & 0.005 & 0.006 \\
$\Sigma B$-site & 5.952 & 5.894 & 6.053 & 5.910 \\
$\mathrm{Si}^{4+}$ & 0.007 & 0.006 & 0.009 & 0.005 \\
$\mathrm{As}^{5+}$ & 0.584 & 0.615 & 0.613 & 0.524 \\
$\mathrm{P}^{5+}$ & 3.401 & 3.369 & 3.378 & 3.457 \\
$\mathrm{~S}^{6+}$ & 0.008 & 0.010 & 0.000 & 0.014 \\
$\Sigma T$-site & 4.000 & 4.000 & 4.000 & 4.000 \\
$\mathrm{H}^{+}$ & 17.448 & 17.880 & 17.261 & 17.266 \\
$\mathrm{PO}_{3} \mathrm{OH}$ & 1.451 & 1.880 & 1.256 & 1.265 \\
$\mathrm{PO}_{4}$ & 1.950 & 1.489 & 2.122 & 2.192 \\
$\mathrm{OH}^{+}$ & 8.000 & 8.000 & 8.000 & 8.000 \\
$\mathrm{H}_{2} \mathrm{O}$ & 3.999 & 4.000 & 4.002 & 4.001 \\
\hline & & & & \\
\hline
\end{tabular}

Average composition and 1,2,3-spot analyses of $\boldsymbol{U N K} 10$.

Empirical formulas were calculated on the basis of $(\mathrm{P}+\mathrm{As}+\mathrm{Si}+\mathrm{S})=4$;

$* \mathrm{H}_{2} \mathrm{O}$ content calculated from the general formula $\left[(\mathrm{OH})=8, \mathrm{H}_{2} \mathrm{O}=4\right]$ and charge balance. ities carry small $(<1 \mathrm{~mm})$ crystalline aggregates of UNK3, overgrown by zoned minerals of the turquoise group, pharmacosiderite, UNK1, and rare kolbeckite and Cl-rich fluorapatite. During the quantitative chemical study of the zoned aggregates of turquoise group minerals, the phase has been found as several irregular zones to 20 by $50 \mu \mathrm{m}$ in size (Fig. 42).

Owing to small dimensions of UNK10 it was not possible to examine this phase by X-ray powder diffraction. Its classification with the turquoise group is based on chemical composition and its presence as zones in minerals of the turquoise group.

The quantitative chemical analyses of UNK10 (Table 21) shows that it is a new mineral phase with stoichiometry corresponding to the turquoise group. The general formula of minerals of the turquoise group is $\mathrm{AB}_{6}\left(\mathrm{TO}_{4}\right)_{4-\mathrm{x}}\left(\mathrm{TO}_{3} \mathrm{OH}\right)_{\mathrm{x}}(\mathrm{OH})_{8} \cdot 4 \mathrm{H}_{2} \mathrm{O}$, where $\mathrm{x}=0-2$ in dependence on occupancy of the $A$-site (Foord - Taggart 1998). The $A$-site can be occupied by $\mathrm{Cu}$ (turquoise, chalcosiderite), $\mathrm{Zn}$ (faustite), $\mathrm{Fe}^{2+}$ (aheylite) and vacancy (planerite); $B$-site is occupied dominantly by $\mathrm{Al}$ and lesser $\mathrm{Fe}$ (chalcosiderite and unnamed $\mathrm{Fe}^{2+}-\mathrm{Fe}^{3+}$ dominant member); the tetrahedral $T$-site is occupied in known members of the series always by phosphorus (Foord Taggart 1998).

The $A$-site of $\boldsymbol{U N K 1 0}$ contains $\mathrm{Cu}(0.17-0.41$ apfu), $\mathrm{Zn}(0.02-0.06 a p f u)$ and only minor $\mathrm{Mn}, \mathrm{Ba}(\max .0 .02$ $a p f u$ ) and $\mathrm{Pb}, \mathrm{Ca}(\max .0 .01 \mathrm{apfu}$ ). These compositional data show dominant vacancy in this position, ranging from 0.51 to 0.78 apfu (Fig. 43). B-site is dominated by Fe (5.03-5.25 apfu), Al corresponds to 0.76-0.88 apfu and Ti does not exceed 0.01 apfu. The tetrahedral $T$-site contains dominant P (3.37-3.46 apfu), regular As (0.52-

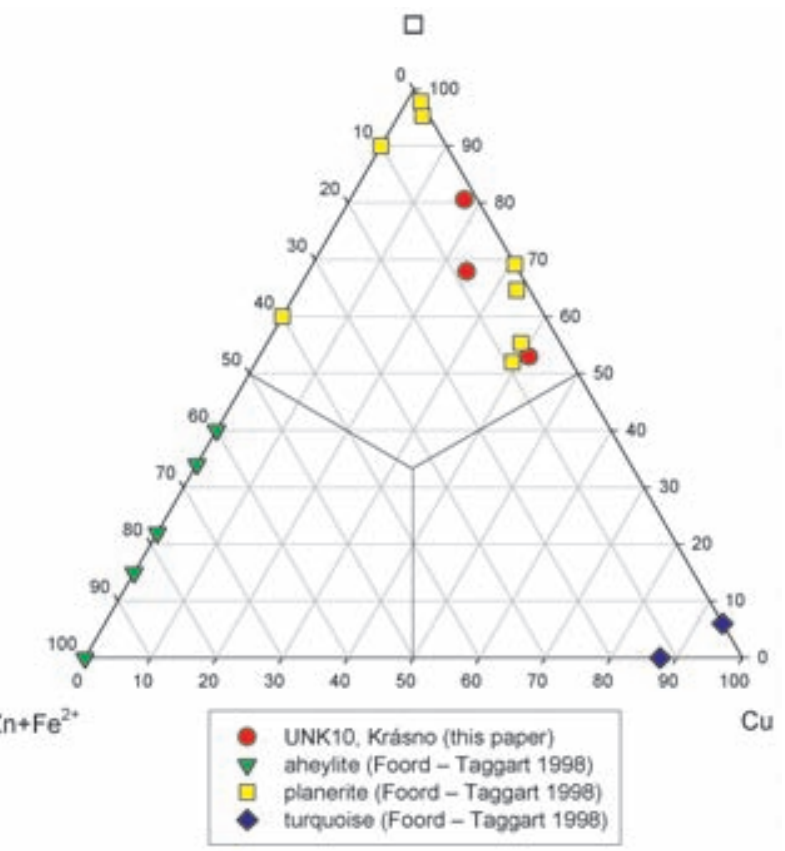

Fig. 43 Ternary plot $\mathrm{Cu}-\square$-( $\mathrm{Fe}^{2+}+\mathrm{Zn}$ ) of $A$-site occupancy (atomic ratios) for $A$-deficient members of the turquoise group. 
0.62 apfu) and minor S and Si (max. 0.01 apfu). Similar contents of As in T-site (max. 0.60-0.64 apfu) were reported in minerals of the chalcosiderite - turquoise from the Huber open pit (Sejkora et al. 2006c) and from greisen at the Vysokém kámen quarry near Krásno (Sejkora et al. 2006a). The empirical formula for UNK10, based on average of three spot analyses and the relationship $(\mathrm{P}+\mathrm{As}+\mathrm{S}+\mathrm{Si})=4$, is $\left(\square_{0.67} \mathrm{Cu}_{0.28} \mathrm{Zn}_{0.04} \mathrm{Mn}_{0.01}\right)_{\Sigma 1.00}$ $\left(\mathrm{Fe}_{5.14} \mathrm{Al}_{0.81} \mathrm{Ti}_{0.01}\right)_{\Sigma 5.96}\left[\left(\mathrm{PO}_{4}\right)_{1.95}\left(\mathrm{PO}_{3} \mathrm{OH}\right)_{1.45}\left(\mathrm{AsO}_{4}\right)_{0.58}\left(\mathrm{SO}_{4}\right)_{0.01}\right.$ $\left.\left(\mathrm{SiO}_{4}\right)_{0.01}\right]_{\Sigma 4.00}(\mathrm{OH})_{8.00} \cdot 4 \mathrm{H}_{2} \mathrm{O}$.

UNK10 is the first $\mathrm{Fe}^{3+}$ member of the turquoise group with dominating vacancy in the $A$-site; its $\mathrm{Al}^{3+}$ analogue - the mineral planerite (Foord - Taggart 1998) is known for a longer time from numerous localities.

\section{UNK11 Ca-Fe phosphate - $(\mathrm{Ca}, \mathrm{Bi})(\mathrm{Fe}, \mathrm{Al})_{3}\left(\mathrm{PO}_{4}\right)\left(\mathrm{PO}_{3} \mathrm{OH}\right)(\mathrm{OH})_{6}$}

UNK11 has been found in cavities in quartz in greisen samples collected behind the area of the former Stannum mine. The material originates in the Huber open pit and it was transported to the place of a secondary occurrence (Novák et al. 2001). UNK11 in a mixture with Sr-Bi-rich crandallite occurs as light yellow-white, yellow-brown or grey aggregates among quartz crystals and mat earthy crusts up to $3 \mathrm{~mm}$ thick on cassiterite and quartz. Soft white dickite aggregates and thin brown-yellow or yellow coatings of varlamoffite (Novák et al. 2001) occur in a close association with $\boldsymbol{U N K} 11$.

Novák et al. (2001) reported that "bismutian ferricrandallite" (i.e., the phase UNK11) very closely associates with $\mathrm{Sr}-\mathrm{Bi}$ crandallite and the two phases are macroscopically indistinguishable. The single additional information about this mineral phase is the following average of three spot analyses (ED analyzer; the analyses were probably normalized to $100 \mathrm{wt}$. \%, fluorine was not analyzed): $14.63 \mathrm{Bi}_{2} \mathrm{O}_{3}, 4.07 \mathrm{CaO}, 3.80 \mathrm{SrO}, 1.82$ $\mathrm{CuO}, 12.45 \mathrm{Al}_{2} \mathrm{O}_{3}, 23.43 \mathrm{Fe}_{2} \mathrm{O}_{3}, 16.36 \mathrm{P}_{2} \mathrm{O}_{5}, 11.52 \mathrm{As}_{2} \mathrm{O}_{5}$, $2.23 \mathrm{SO}_{3}, 10.17 \mathrm{H}_{2} \mathrm{O}$ (calculated on the basis of charge balance and $(\mathrm{OH})=6$ ), total 100.48 wt. \%. With regard to the general formula of the crandallite group $\mathrm{A}^{2+, 3+} \mathrm{B}^{3+, 2+}{ }_{3}\left(\mathrm{TO}_{4}\right)\left(\mathrm{TO}_{3} \mathrm{OH}\right)(\mathrm{OH})_{6}$, it is possible to express the empirical formula for $\boldsymbol{U N K} \mathbf{1 1}$ on the basis of $(\mathrm{P}+\mathrm{As}+\mathrm{S})=2$ as $\left(\mathrm{Ca}_{0.40} \mathrm{Bi}_{0.35} \mathrm{Sr}_{0.20}\right)_{\Sigma 0.95}\left(\mathrm{Fe}_{1.64} \mathrm{Al}_{1.36} \mathrm{Cu}_{0.13}\right)_{\Sigma 3.13}$ $\left[\left(\mathrm{PO}_{4}\right)_{0.96}\left(\mathrm{PO}_{3} \mathrm{OH}\right)_{0.32}\left(\mathrm{AsO}_{4}\right)_{0.56}\left(\mathrm{SO}_{4}\right)_{0.16}\right]_{\Sigma 2.00}(\mathrm{OH})_{6.00}$. Although there are high $\mathrm{Bi}, \mathrm{Al}$ and $\mathrm{As}$ contents in individual sites, the empirical formula defines a new mineral species - Ca-Fe-P dominated member of the crandallite group ( $\mathrm{Fe}$ analogue of crandallite or $\mathrm{Ca}$ analogue of zairite).

\section{Conclusion}

The complex mineralogical study in the Krásno - Horní Slavkov area, western Bohemia, Czech Republic, indicates the presence of the following eleven probably new mineral species:
UNK1 - hexagonal, $(\mathrm{Ca}, \mathrm{Sr})_{3} \mathrm{Al}_{7}\left(\mathrm{SiO}_{4}\right)_{3}\left(\mathrm{PO}_{4}\right)_{3}(\mathrm{~F}, \mathrm{OH})_{3}$. $16.5 \mathrm{H}_{2} \mathrm{O}$

Probably fluorine analogue of perhamite, defined on the basis of X-ray powder diffraction data, refined unitcell parameters and quantitative chemical analyses. A mineral phase of comparable composition is not described in the available literature.

$\boldsymbol{U N K} 2$ - triclinic, $\mathrm{Cu}_{13}\left(\mathrm{AsO}_{4}\right)_{6}\left(\mathrm{AsO}_{3} \mathrm{OH}\right)_{4} \cdot 23 \mathrm{H}_{2} \mathrm{O}$

$\mathrm{A} \mathrm{Cu}$-arsenate that is structurally different from known minerals and synthetic materials. It is defined on the basis of X-ray powder diffraction data, refined unit-cell parameters and semi-quantitative chemical analyses. In the course of study of this phase in samples from Krásno, well-formed crystals of UNK2 have been found in samples from the Jáchymov ore district (Krušné hory Mts., Czech Republic). Results of a detailed study of these crystals, including quantitative chemical analyses and crystal structure identification based on single-crystal $\mathrm{X}$-ray diffraction were submitted as a new mineral proposal to the Commission on New Minerals and Mineral names of the International Mineralogical Association. The proposal was approved under the number IMA 2004-38 as a new mineral species.

UNK3 - orthorhombic (?) - $\mathrm{Zn}\left(\mathrm{Fe}, \mathrm{Zn}, \mathrm{Al}_{4}\left(\mathrm{PO}_{4}\right)_{3}(\mathrm{OH})_{4}(\right.$ ?)

Probably $\mathrm{Zn}$ analogue of rockbridgeite and frondelite, defined on the basis of X-ray powder diffraction data, refined unit-cell parameters and quantitative analyses. No description of a mineral phase of comparable composition has been found in the literature.

UNK4 - trigonal (?), $\mathrm{CaAl}_{3}\left(\mathrm{PO}_{4}\right)\left(\mathrm{PO}_{3} \mathrm{OH}\right)(\mathrm{OH}, \mathrm{F})_{6}(?)$

Fluorine-rich $\mathrm{Ca}-\mathrm{Al}$ phosphate, probably structurally related to crandallite. It was defined in mixture with fluorapatite on the basis of X-ray powder diffraction data, refined unit-cell parameters and quantitative analyses. No description of a mineral phase of comparable composition has been found in the literature.

UNK5 - $\mathrm{Pb}\left(\mathrm{UO}_{2}\right)_{3} \mathrm{O}_{3}(\mathrm{OH})_{2}$. $3 \mathrm{H}_{2} \mathrm{O}(?)$

$\mathrm{Pb}-\mathrm{U}$-oxide/hydroxide mineral without direct structural relation to known mineral species. It is defined on the basis of X-ray powder diffraction data and chemical composition, which is near to the composition of masuyite. The X-ray data indicate that this phase is identical with the unnamed mineral („PbO- $\mathrm{UO}_{3}-\mathrm{H}_{2} \mathrm{O}$ phase“) from Rovnost mine, Jáchymov (Ondruš et al. 1997).

UNK6 - monoclinic, $\mathrm{CuFe}_{2}^{3+}\left(\mathrm{PO}_{4}\right)_{2}(\mathrm{OH})_{2} \cdot 4 \mathrm{H}_{2} \mathrm{O}$

$\mathrm{Cu}, \mathrm{Fe}^{3+}, \mathrm{P}$ - dominant member of the arthurite group, $\mathrm{P}$-analogue of arthurite, defined on the basis of X-ray powder diffraction data, refined unit-cell parameters and quantitative analyses.

A mineral phase from Hingston Down, Consols mine, Calstock, Cornwall (Great Britain), probably identical with UNK6, is mentioned by Frost et al. (2003) under the name of arthurite; however, the data by Frost et al. (2003) are only of a preliminary character.

$\boldsymbol{U N K} 7$ - monoclinic (?), $\mathrm{ZnFe}^{3+}{ }_{2}\left(\mathrm{PO}_{4}\right)_{2}(\mathrm{OH})_{2} \cdot 4 \mathrm{H}_{2} \mathrm{O}$

$\mathrm{Zn}, \mathrm{Fe}^{3+}, \mathrm{P}-$ dominated member of the arthurite group, P-analogue of ojuelaite, has been defined on the 
basis of chemical analyses. No description of a mineral phase of comparable composition has been found in the literature.

UNK8 - monoclinic (?), $\mathrm{Fe}^{2+} \mathrm{Al}_{2}\left(\mathrm{PO}_{4}\right)_{2}(\mathrm{OH})_{2} \cdot 4 \mathrm{H}_{2} \mathrm{O}$

$\mathrm{Fe}^{2+}, \mathrm{Al}^{3+}, \mathrm{P}$ - dominant member of the arthurite group, Al-analogue of whitmoreite, defined only on the basis of chemical analyses. No description of a mineral phase of comparable composition has been found in the literature.

UNK9 - monoclinic, $\left(\mathrm{Mn}^{2+}, \mathrm{Fe}^{2+}\right)_{2}\left(\mathrm{Fe}^{3+}, \mathrm{Al}\right)_{3}\left(\mathrm{PO}_{4}\right)_{3}(\mathrm{OH})_{4}$ . $\mathrm{H}_{2} \mathrm{O}$

Fe-Mn phosphate, unrelated to compounds of a similar composition. It is defined on the basis of X-ray powder diffraction data and quantitative chemical analyses. The phase is probably identical with unnamed "dufrénitelike" mineral from Buranga (Knorring - Sahama 1982) and related to (Mn analogue of ?) an unnamed Fe phosphate from Rothläufchen mine, Waldgirmes (Frondel 1949).

UNK10 - triclinic (?), $(\square, \mathrm{Cu}) \mathrm{Fe}^{3+}{ }_{6}\left(\mathrm{PO}_{4}\right)_{2}\left(\mathrm{PO}_{3} \mathrm{OH}\right)_{2}$ $(\mathrm{OH})_{8} \cdot 4 \mathrm{H}_{2} \mathrm{O}$

$\square, \mathrm{Fe}^{3+}, \mathrm{P}-$ dominant member of the turquoise group, $\mathrm{Fe}^{3+}$-analogue of planerite, defined only on the basis of quantitative chemical analyses. No description of a mineral phase of comparable composition has been found in the literature.

UNK11 - trigonal(?), (Ca,Bi)(Fe,Al) ${ }_{3}\left(\mathrm{PO}_{4}\right)$ $\left(\mathrm{PO}_{3} \mathrm{OH}\right)(\mathrm{OH})_{6}$

$\mathrm{Ca}, \mathrm{Fe}^{3+}, \mathrm{P}-$ dominated member of the crandallite group, $\mathrm{Ca}$-analogue of zairite or $\mathrm{Fe}^{3+}$-analogue of crandallite, defined only on the basis of quantitative chemical composition. No description of a mineral phase of comparable composition has been found in the literature.

Acknowledgements. The authors gratefully acknowledge cooperation of Jiří Litochleb, Jiří Čejka (National Museum, Prague), Stanislav Vrána, František Veselovský, Ananda Gabašová (Czech Geological Survey, Prague), Jakub Plášil, Pavel Škácha (Faculty of Science, Charles University, Prague), Jana Ederová (Institute of Chemical Technology, Prague) and numerous colleagues who kindly provided samples for this study - Ctibor Süsser (Sokolov), Jaromír Tvrdý (Karlovy Vary), Pavel Beran (Sokolov) and others.

This work was supported by Grants from the Ministry of Culture of the Czech Republic (Project MK00002327201) and the Granting Agency of the Czech Republic (Grant No. 205/03/D004).

Submitted September 9, 2006

\section{References}

Beran, P. - Sejkora, J. (2006): The Krásno Sn-W ore district near Horní Slavkov: mining history, topographical, geological and mineralogical characteristics. - Journ. Czech Geol. Soc., 51: 3-42

Blount, A. M. (1974): The crystal structure of crandallite. - Amer. Mineral., 59: 41-47.

Burnham, C. W. (1962): Lattice constant refinement. Carnegie Inst. Washington Year Book 61: 132-135.
Burns, P. C. (1997): A new uranyl oxide hydrate sheet in vandendriesscheite: Implication fro mineral paragenesis and the corrosion of spent nuclear fuel. - Amer. Mineral., 82, 1176-1186.

- (1998): The structure of richetite, a rare lead uranyl oxide hydrate. Can. Mineral., 36: 187-199.

Burns, P. C. - Hanchar, J. M. (1999): The structure of masuyite, $\mathrm{Pb}\left[\left(\mathrm{UO}_{2}\right)_{3} \mathrm{O}_{3}(\mathrm{OH})_{2}\right]\left(\left(\mathrm{H}_{2} \mathrm{O}\right)_{3}\right.$, and its relationship to protasite. - Can. Mineral., 37: 1483-1491.

Cesbron, F. - Romero, M. - Williams, S. A. (1981): La mapimite et l'ojuelaite, deux nouveaux arséniates hydratés de zinc et de fer de la mine Ojuela, Mapimi, Mexique. - Bull. Minéral., 104: 582-586.

Christ, C. L. - Clark, J. R. (1960): Crystal chemical studies of some uranyl oxide hydrates. - Amer. Mineral., 45, 1026-1061.

Cowgill, U. M. - Hutchinson, G. E. - Joensuu, O. (1963): An apparently triclinic dimorph of crandallite from a tropical swamp sediment in El Petén, Guatemala. - Amer. Mineral., 48: 1144-1153.

Davis, R. J. - Hey, M. H. (1964): Arthurite, a new copper-iron arsenate from Cornwall. - Mineral. Mag. 33, 937-941

- (1969): The cell-contents of arthurite redetermined. - Mineral. Mag., 37, 520-521.

Deliens, M. - Piret, P. (1996): Les Masuyites de Shinkolobwe (Shaba, Zad're) constituent un groupe formé de deux variétés distinctes par leur composition chimique et leurs propriétés radiocristallographiques. - Bull. Inst. Roayl Scinces Natur. Belgique, Sciences de la Terre, 66: 187-192.

Dunn, P. J. - Appleman, D. E. (1977): Perhamite, a new calcium aluminum silico-phosphate mineral, and a re-examination of viséite. - Mineral. Mag. 41: 437-442.

Finch, R. J. - Ewing, R. C. (1992): The corrosion of uraninite under oxidizing conditions. - Journ. Nucl. Mater., 190: 133-156.

Foord, E. E. - Taggart, J. E. Jr. (1998): A re-examination of the turquoise group: the mineral aheylite, planerite (redefined), turquoise and coeruleolactite. - Mineral. Mag. 62: 93-111.

Frondel, C. (1949): The dufrenite problem. - Am. Mineral., 34: 513-539.

Frost, R. L. - Duong, L. - Martens, W. (2003): Molecular assembly in secondary minerals - Raman spectroscopy of the arthurite group species arthurite and whitmoreite. - N. Jb. Miner. Mn., 223-240.

Hughes, J. M. - Bloodaxe, E. S. - Kobel, K. D. - Drexler, J. W. (1996): The atomic arrangment of ojuelaite, $\mathrm{ZnFe}_{2}{ }^{3+}\left(\mathrm{AsO}_{4}\right)_{2}(\mathrm{OH})_{2} \cdot 4 \mathrm{H}_{2} \mathrm{O}$. Mineral. Mag., 60, 519-521.

Jambor, J. L. - Vinalas, J. - Groat, L. A. - Raudsepp, M. (2002): Cobaltarthurite, $\mathrm{Co}^{2+} \mathrm{Fe}^{3+}{ }_{2}\left(\mathrm{AsO}_{4}\right)_{2}(\mathrm{OH})_{2} .4 \mathrm{H}_{2} \mathrm{O}$. a new member of the arthurite group. - Can. Mineral., 40, 725-732.

Kampf, A. R. (2005): The crystal structure of cobaltarthurite from the Bou Azzer district, Morocco: the location of hydrogen atoms in the arthurite structure-type. - Can. Mineral., 43: 1387-1391.

Keller, P. - Hess, H. (1978): Die Kristallstruktur von Arthurit, $\mathrm{CuFe}_{2}{ }^{3+}$ $\left[\left(\mathrm{H}_{2} \mathrm{O}\right)_{4}\left|(\mathrm{OH})_{2}\right|\left(\mathrm{AsO}_{4}\right)_{2}\right]$. - N. Jb. Miner. Abh., 133: 291-302.

Knorring v., O. - Sahama, T. G. (1982): Some FeMn phosphates from the Buranga pegmatite, Rwanda. - Schweiz. mineral. petrogr. Mitt., 62: 343-352

Li, Y. - Burns, P. C. (2000a): Investigations of crystal chemistry variability in lead uranyl oxide hydrates. II. Fourmarierite. - Can. Mineral.; 38, 797-749.

- (2000b): Synthesis and crystal structure of a new Pb uranyl oxide hydrate with a framework structure that contains channels. - Can. Mineral., 38: 1433-1441.

Mills, S. J. - Frost, R. L. - Grey, I. E. - Mumme, W. G. - Weier, M. L. (2004): Crystallography, Raman and IR spectroscopy of perhamite - an interesting silico-phosphate. - Mitt. Österr. Miner. Ges., 149: 68.

Moore, P. B. (1970): Crystal chemistry of the basic iron phosphates. Amer. Mineral. 55: 135-169.

Moore, P. B. - Kampf, A. R. - Irving, A. J. (1974): Whitmoreite. $\mathrm{Fe}^{2+} \mathrm{Fe}^{3+}{ }_{2}(\mathrm{OH})_{2}\left(\mathrm{H}_{2} \mathrm{O}\right)_{4}\left[\mathrm{PO}_{4}\right]_{2}$, a new species: its description and atomic arrangement. - Am. Mineral., 59: 900-905.

Novák, F. - Pauliš, P. - Süsser, C. (2001): Chemical composition of crandallite, goyazite and waylandite from Krásno near Horní Slavkov. - Chemické složení crandallitu, goyazitu a waylanditu z Krásna 
u Horního Slavkova. - Bull. mineral. - petrolog. Odd. Nár. Muz. (Praha), 9: 230-234. (in Czech)

Ondruš, P. (1993): ZDS - A computer program for analysis of X-ray powder diffraction patterns. - Materials Science Forum, 133-136: 297300, EPDIC-2. Enchede.

Ondruš, P. - Skála, R. (1997): New quasi-empirical channel Search/Match algorithm for ICDD PDF2 Database: A tool for qualitative phase analysis integrated in the ZDS-System software package for X-ray powder diffraction analysis - Fifth European Powder Diffraction Conference EPDIC-5, 193. Parma.

Ondruš, P. - Veselovský, F. - Skála, R. - Císařová, I. - Hloušek, J. Frýda, J. - Vavřin, I. - Čejka, J. - Gabašová, A. (1997): New naturally occurring phases of secondary origin from Jáchymov (Joachimsthal). - Jour. Czech Geol. Soc., 42: 77-107.

Pagoaga, M. K. (1983): The crystal chemistry of the uranyl oxide hydrate minerals. - PhD Thesis, University of Maryland.

Peacor, D. R. - Dunn, P. J. - Simmons, W. B. (1984): Earlshannonite, the $\mathrm{Mn}$ analogue of whitmoreite, from North Carolina. - Can. Mineral., 22: 471-474.

Pilkington, E. S. -Segnit, E. R. - Watts, J. -Francis, G. (1979): Kleemanite, a new zinc aluminium phosphate. - Mineral. Mag., 43, 93-95.

Piret, $P$. (1985): Structure cristalline de la fourmarierite, $\mathrm{Pb}\left(\mathrm{UO}_{2}\right)_{4} \mathrm{O}_{3}(\mathrm{OH})_{4}$ . $4 \mathrm{H}_{2} \mathrm{O}$. - Bull. Minéral., 108, 659-665.

Piret, P. -Deliens, M. - Piret-Meunier, J. - Germain, G. (1983): La sayrite, $\mathrm{Pb}_{2}\left[\left(\mathrm{UO}_{2}\right)_{5} \mathrm{O}_{6}(\mathrm{OH})_{2}\right] .4 \mathrm{H}_{2} \mathrm{O}$, nouveau minéral; properiétés et structure cristalline. - Bull. minéral., 106: 299-304.
Piret, P. - Deliens, M. (1984): Nouvelles données sur la richetite $\mathrm{PbO} .4 \mathrm{UO}_{3} .4 \mathrm{H}_{2} \mathrm{O}$. - Bull. Minéral., 107: 581-585.

Plášil, J. -Sejkora, J. -Ondruš, P. -Veselovský, F. - Beran, P. - Goliáš, V. (2006): Supergene minerals in the Horní Slavkov uranium ore district, Czech Republic. - Journ. Czech Geol. Soc., 51: 149-158.

Pouchou, J. L. - Pichoir, F. (1985): "PAP" procedure for improved quantitative microanalysis. - Microbeam Analysis 20:104-105.

Raudsep, M. (1995): Recent advances in the electron-probe analysis of minerals for the light elements. - Canad. Mineral., 33: 203-218.

Rodriguez-Carvajal, J. (2005): Computer Program FullProf, ver. December 2005. - Laboratoire Leon Bril-louin (CEA-CNRS), France.

Sejkora, J. -Ondruš, P. - Fikar, M. - Veselovský, F-Mach, Z. - Gabašová, A. (2006a): New data on mineralogy of the Vysoký Kámen deposits near Krásno, Slavkovský les area, Czech Republic. - Journ. Czech Geol. Soc., 51: 43-55.

Sejkora, J. - Ondruš, P. - Fikar, M. - Veselovský, F-Mach, Z. - Gabašová, A. - Škoda, R. - Beran, P. (2006b): Supergene minerals at the Huber stock and Schnöd stock deposits, Krásno ore district, the Slavkovský les area, Czech Republic. - Journ. Czech Geol. Soc., 51: 57-101.

Sejkora, J. - Škoda, R. - Ondruš, P. - Beran, P. - Süsser, C. (2006c): Mineralogy of phosphate accumulations in the Huber stock, Krásno ore district, Slavkovský les area, Czech Republic. - Journ. Czech Geol. Soc., 51: 103-147.

Staněk, J. (1988): Paulkerrite and earlshannonite from pegmatite near Dolní Bory (western Moravia, Czechoslovakia). - Čas. Morav. Muz., Vědy prír., 73: 29-34.

\section{Nové minerální fáze z oblasti Krásno - Horní Slavkov, západní Čechy, Česká republika}

V práci je popsáno jedenáct pravděpodobně nových minerálních druhů, pocházejících z oblasti Krásno - Horní Slavkov, západní Čechy, Česká republika. Mezi zjištěnými novými druhy převažují supergenní fosfáty, dále byl zjištěn i jeden arsenát a hydroxid Pb-U. Podány jsou všechna dostupná fyzikální a chemická data pro jednotlivé zjištěné nové minerální druhy, stejně jako citace související literatury. 